\title{
Electrochemical Activation of Galactose Oxidase: Mechanistic Studies and Synthetic Applications
}

\author{
Shaoguang Zhang, Serge Ruccolo, ${ }^{*}$ Anna Fryszkowska, Artis Klapars, Nicholas Marshall, \\ Neil A. Strotman
}

Process Research and Development, Merck \& Co., Inc., Rahway, NJ 07065, USA

Corresponding author: serge.ruccolo@merck.com

\section{Table of Contents}

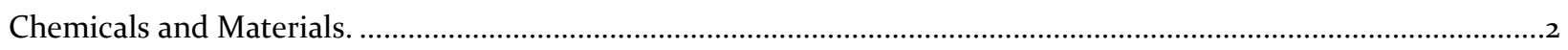

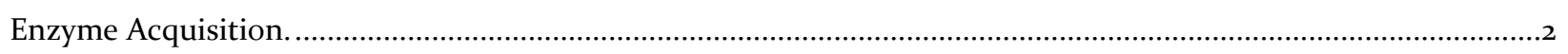

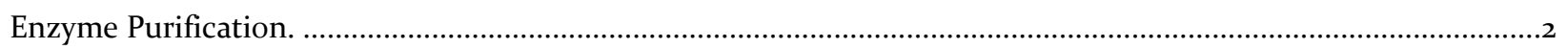

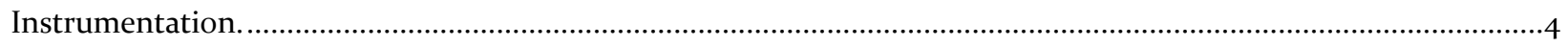

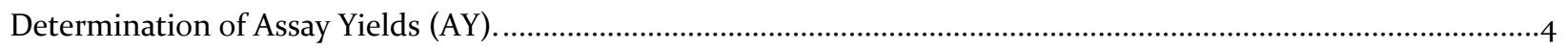

Electrosynthesis Equipment...........................................................................................................................

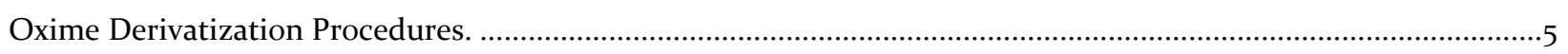

Bioelectrosynthesis of $(R)$-2-ethynylglyceraldehyde from 2-ethynylglycerol. ...........................................................5

General procedure for bioelectrosynthesis of aldehydes from benzyl alcohol derivatives or cinnamyl alcohol using

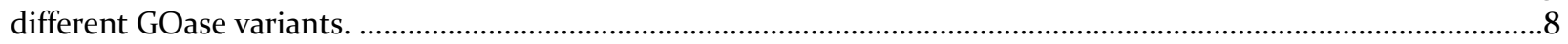

General procedure for bioelectrosynthesis of aldehydes from aliphalic poly-ols using different GOase variants. ....9

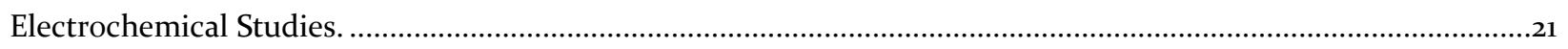

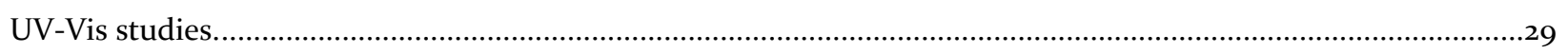

Enzyme activity assay ....................................................................................................................................3

Amino acid and DNA sequences of the GOase enzymes...................................................................................3

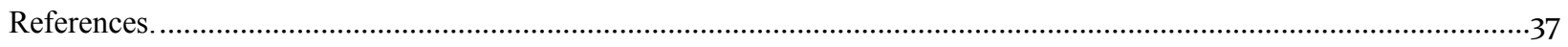




\section{Chemicals and Materials.}

Unless stated otherwise, all the reagents and solvents were purchased from commercial suppliers (Acros, Merck Millipore Sigma, TCI America, Fisher Scientific, etc) and were of the highest analytical purity. Deionized water (UPLC grade) was used for all experiments. $N, N, N$-Trimethyl-1-ferrocenylmethanaminium chloride ${ }^{[1]}$, ferrocenecarboxylic acid sodium salt ${ }^{[2]}$ and 2-ethynylglycerol solution in buffer ${ }^{[3,4]}$ were synthesized following previously published procedures. For cyclic voltammetry experiments, a 2-ethynylglycerol solution $(18 \mathrm{wt} \%, 1.58$ $\mathrm{M}$ ) was used; for electrosynthesis, 2-ethynylglycerol solution ( $1 \mathrm{M}$ in $0.56 \mathrm{M} \mathrm{NaPi} \mathrm{pH}$ 7.o buffer) was prepared by dissolving $13.8 \mathrm{~g}$ of the corresponding sodium salt in $60 \mathrm{~mL}$ of water, adjusting the $\mathrm{pH}$ to $\mathrm{pH} 7.0$ by adding $3.43 \mathrm{~mL}$ of o-phosphoric acid $(85 \%, 6.43 \mathrm{~g})$ and then adding more water until the total volume was $100 \mathrm{~mL}$. o.1 $\mathrm{M} \mathrm{CuSO}_{4}$ stock solution was prepared by dissolving $250 \mathrm{mg}$ of $\mathrm{CuSO}_{4}{ }_{5} \mathrm{H}_{2} \mathrm{O}$ in $5 \mathrm{~mL}$ of water and then adding more water until the total volume was $10 \mathrm{~mL}$. $1 \mathrm{mM} \mathrm{CuSO}_{4}$ stock solution was prepared by diluting $0.4 \mathrm{~mL}$ of o.1 $\mathrm{M} \mathrm{CuSO}_{4}$ stock solution into $39.6 \mathrm{~mL}$ of $\mathrm{H}_{2} \mathrm{O} .10 \mathrm{mM}$ mediator stock solutions were prepared by dissolving $0.01 \mathrm{mmol}$ of mediator into $1 \mathrm{~mL}$ of $0.1 \mathrm{M} \mathrm{NaPi}$ buffer. Stock solutions of $100 \mathrm{mM} \mathrm{Na}_{2} \mathrm{~S}_{2} \mathrm{O}_{8}$ were prepared by dissolving $23.8 \mathrm{mg} \mathrm{of} \mathrm{Na}_{2} \mathrm{~S}_{2} \mathrm{O}_{8}$ in $1 \mathrm{~mL}$ in o.1M NaPi buffer. $\mathrm{D}_{2} \mathrm{O}(\mathrm{D}$, 99.96\%) was purchased from Cambridge Isotope Laboratories. Maleic acid in $\mathrm{D}_{2} \mathrm{O}$ (0.2, 0.25 or $\left.0.5 \mathrm{wt} \%\right)$ as NMR internal standard was prepared by dissolving 200,250 or $500 \mathrm{mg}$ of NMR grade maleic acid into $100 \mathrm{~mL}$ of $\mathrm{D}_{2} \mathrm{O}$, respectively. The side products (e.g. formic acid, 2-ethynylglyceric acid, unreacted 2-ethynylglycerol) were detected by ${ }^{1} \mathrm{H}$ NMR spectroscopy by sampling a measured aliquot of the reaction mixture into a solution of $\mathrm{D}_{2} \mathrm{O}$ containing maleic acid as internal standards.

\section{Enzyme Acquisition.}

GALO-104 and GALO-105 were prepared as described previously. ${ }^{[3,5]}$ GOase variants $\mathbf{M}_{1}, \mathbf{F}_{2}$ and $\mathbf{M}_{3-5}$ from Fusarium graminearum were purchased from Prozomix, UK. Bovine catalase (Bos taurus) was purchased from Millipore Sigma ( $\mathrm{C}_{1345} ; 5, \mathrm{oooU} / \mathrm{mg}$ ). Horseradish peroxidase (HRP PEO-301) isolated from horseradish roots (Amoracia rusticana) was purchased from Toyobo USA, Inc.

\section{Enzyme Purification.}

For spectroscopic and cyclic voltammetry studies requiring purified enzyme, the purification of the GALO-104 was performed by Evotec, USA. 4L E. coli culture expressing copper-free GALO-104 was lysed, clarified by resuspending into Buffer A (see below). The suspension was clarified by centrifugation, loaded on the column and eluted with the buffer gradient, as described below.

Abbreviations:

HEPES - (4-(2-hydroxyethyl)-1-piperazineethanesulfonic acid

IMAC - immobilized metal-ion affinity chromatography

SEC - size-exclusion chromatography

Purification steps: IMAC/SEC

Mass: observed: 69,485 Da; calculated.: 69,498 Da

Column: 25 mL His Trap FF

Buffer A: $50 \mathrm{mM}$ HEPES pH 7.5, 300mM NaCl, 10mM Imidazole

Buffer B: 50 mM HEPES $\mathrm{pH} 7.5,300 \mathrm{mM} \mathrm{NaCl}$, 50omM Imidazole

Gradient: o\% B over ${ }_{15} \mathrm{CV}$, o-100\% B over 5 CV, o\% B for $10 \mathrm{CV}$

Pool: B1o-F3; ,19.9mg/mL x $100 \mathrm{~mL}=1395 \mathrm{mg}$ 

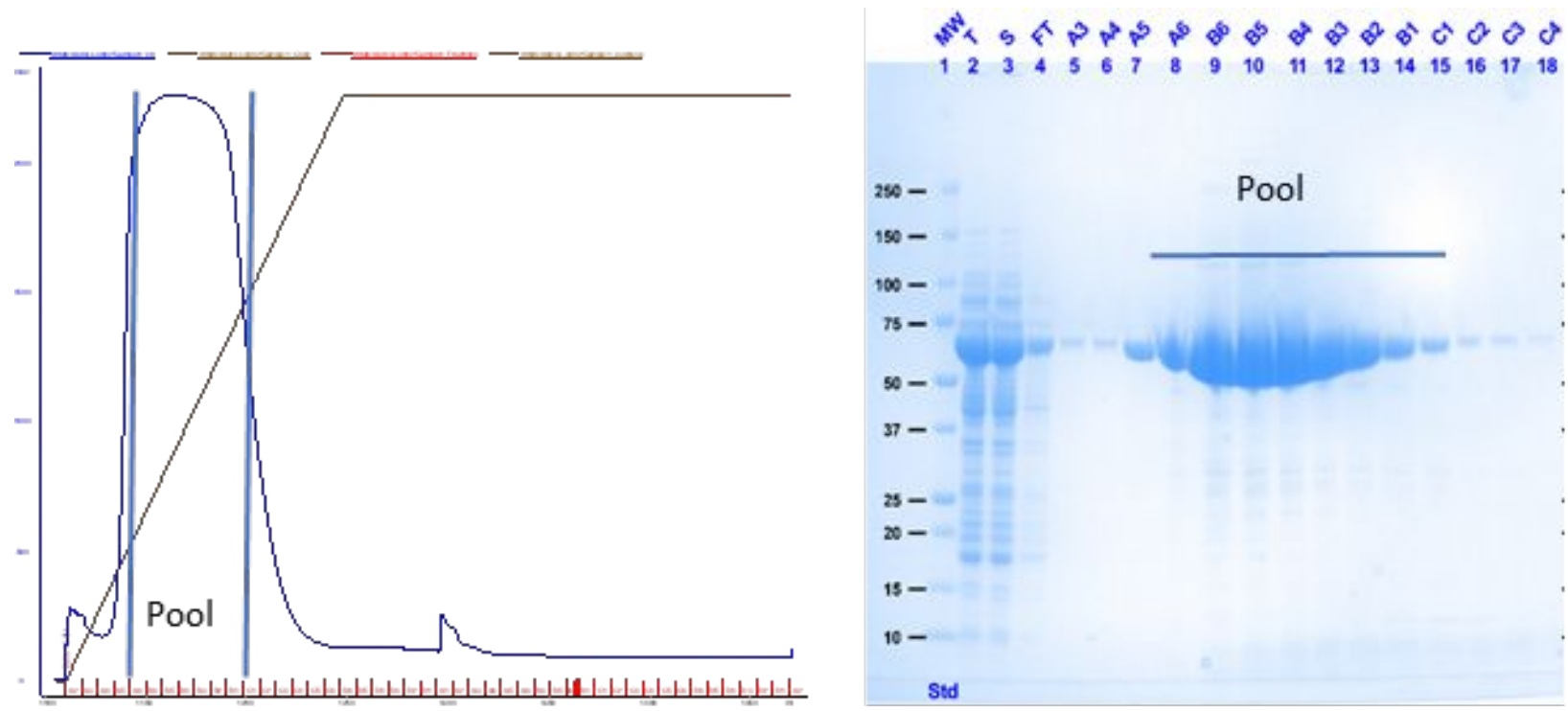

Figure S1: IMAC purification of GALO-104

SEC-purification:

Column: 26/60o S200

SEC Buffer: 50 mM HEPES pH 7.5

Sample: $6 \times 15 \mathrm{~mL}$ injection

Pool: $1.06 \mathrm{mg}$, aliquots of $25 \mathrm{mg} / \mathrm{mL}$ were stored at $-80^{\circ} \mathrm{C}$

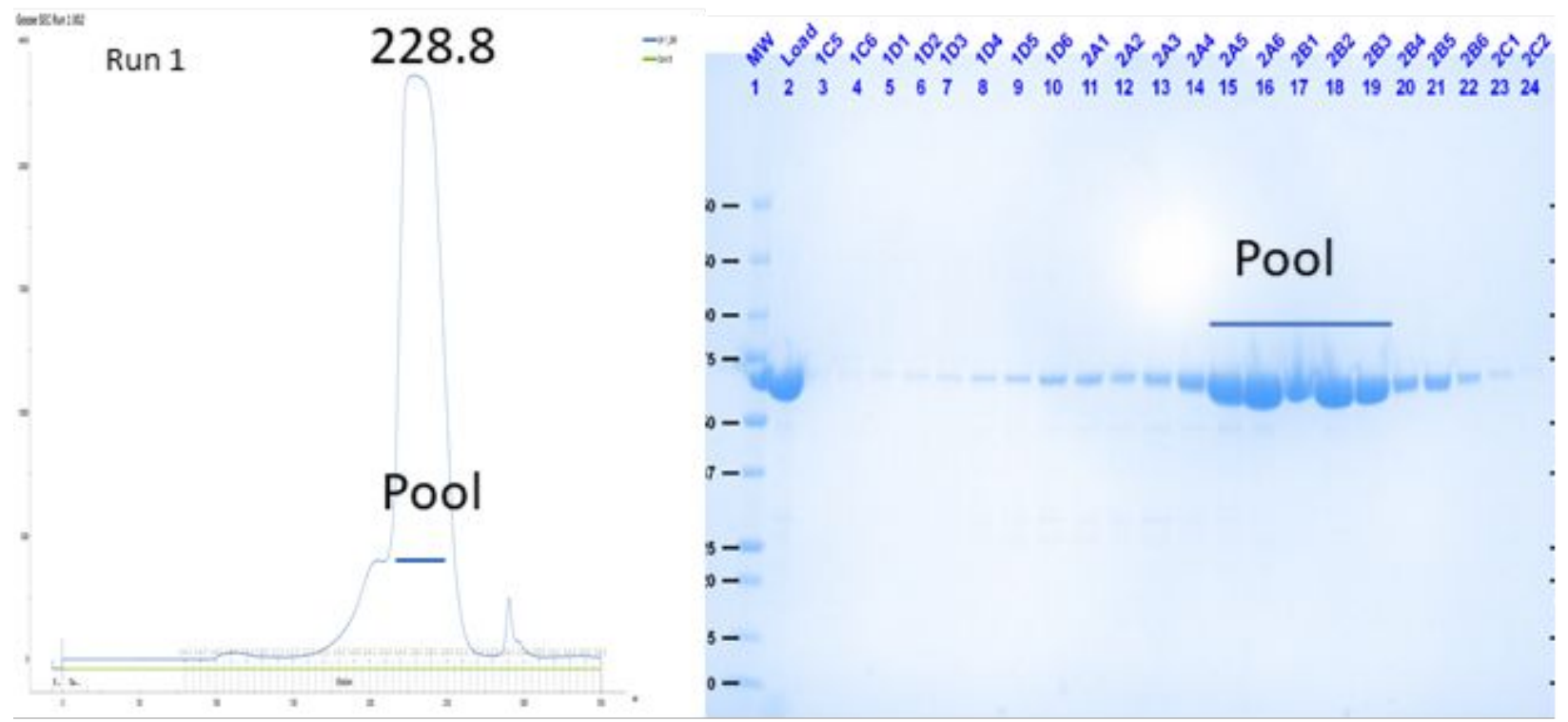




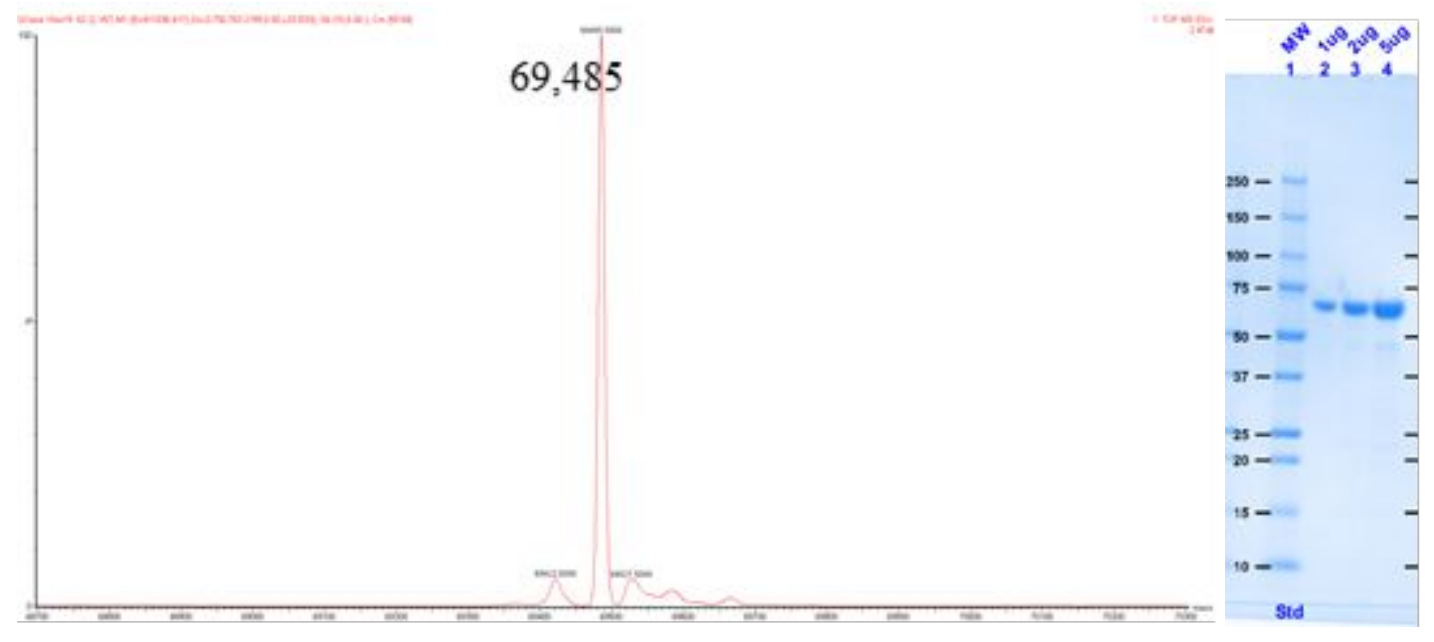

Figure S2: MS and SDS analysis of the purified GALO-104

Before use, the buffer of the GOase solution was exchanged with o.1M NaPi buffer, $\mathrm{pH} 7$ using a $30 \mathrm{kDa}$ molecular weight cut-off filter. The GOase concentration was checked using the absorption at $280 \mathrm{~nm}\left(\varepsilon_{280}=126488 \mathrm{~cm}^{-1} \cdot \mathrm{M}^{-}\right.$ ${ }^{1}$ for GALO-104).

\section{Instrumentation.}

${ }^{1} \mathrm{H}$ NMR spectra were recorded on $500 \mathrm{MHz}$ Bruker UltraShield spectrometer and chemical shifts are reported in ppm and referenced to residual solvent peaks while coupling constants are reported in hertz. ${ }^{1} \mathrm{H}$ NMR with water suppression through presaturation were acquired on a sample dissolved in $\mathrm{D}_{2} \mathrm{O}$. Proton signals were referenced to the HOD peak at $4.70 \mathrm{ppm}$. Supercritical fluid chromatography (SFC) was performed using Waters Acquity UPC2 instrument equipped with UV detector. Enantiomers of the oxime derivatives of 2-ethynylglyceraldehyde were separated using Chiralpak AD-3 $(4.6 \mathrm{~mm} \times 25 \mathrm{~cm})$ column.

\section{Determination of Assay Yields (AY).}

The assay yields were determined by comparing the peak integrations of the desired products against the values of an internal standard on ${ }^{1} \mathrm{H}$ NMR spectra. For the aldehyde products presenting equilibria with their corresponding hydrate form (such as 4-cyanobenzaldehyde, 3,5-dinitrobenzaldehyde, etc) on ${ }^{1} \mathrm{H}$ NMR spectra, the sum of the peak integrations for the protons in the product and its hydrate was used to calculate the assay yield.

$\mathrm{AY}=\frac{\frac{\Sigma \mathrm{H}_{\text {Prod }}}{\Sigma \mathrm{H}_{I S}} \times N_{\mathrm{IS}} \times n_{\mathrm{IS}}}{N_{\text {Prod }} \times n_{\mathrm{Rxn}} \times \frac{\mathrm{v}_{S p l}}{\mathrm{v}_{R x n}}}$

$n_{\mathrm{IS}}=\frac{V_{\mathrm{IS}} \times C_{\mathrm{IS}}}{M w_{\mathrm{IS}}}\left(\mathrm{S}_{2}\right)$

$N_{\text {Prod }}$ : numbers of the proton for the observed peak of the product on ${ }^{1} \mathrm{H}$ NMR spectrum

$N_{\text {IS }}$ : numbers of the proton for the observed peak of the internal standard on ${ }^{1} \mathrm{H}$ NMR spectrum

$n_{\mathrm{rxn}}$ : molar scale of the reaction

$n_{\mathrm{IS}}$ : molar amount (mmol) of the internal standard mixed into the reaction mixture for NMR analysis

$N_{\text {Prod }}$ integration of the proton for the observed peak of the product on ${ }^{1} \mathrm{H}$ NMR spectrum

$\Sigma \mathrm{H}_{\mathrm{IS}}$ : integration of the proton for the observed peak of the internal standard on ${ }^{1} \mathrm{H}$ NMR spectrum

$V_{\text {Spl }}$ : volume $(\mathrm{mL})$ of the reaction mixture sampled for NMR analysis

$V_{\mathrm{Rxn}}$ : total volume $(\mathrm{mL})$ of the reaction mixture 
$V_{\mathrm{IS}}$ : volume $(\mathrm{mL})$ of the internal standard mixed into the reaction mixture for NMR analysis

$C_{\mathrm{IS}}$ : weight ratio percentage concentration (wt\%) of the internal standard

$M w_{\text {IS }}$ : molecular weight $(\mathrm{g} / \mathrm{mol})$ of the internal standard

For example, for the bioelectrocatalytic oxidation of benzyl alcohol (Table 4, entry 1):

$$
\begin{aligned}
& n_{\mathrm{IS}}=\frac{V_{\mathrm{IS}} \times C_{\mathrm{IS}}}{M w_{\mathrm{IS}}}=\frac{0.5 \mathrm{~mL} \times 2.5 \mathrm{mg} / \mathrm{mL}}{116 \mathrm{~g} / \mathrm{mol}}=0.0108 \mathrm{mmol} \\
& \mathrm{AY}=\frac{\frac{\Sigma \mathrm{H}_{\text {Prod }}}{\Sigma \mathrm{H}_{I S}} \times N_{\mathrm{IS}} \times n_{\mathrm{IS}}}{N_{\text {Prod }} \times n_{\mathrm{Rxn}} \times \frac{\mathrm{V}_{S p l}}{\mathrm{~V}_{R x n}}}=\frac{\frac{0.592}{1.0} \times 2 \times 0.0108 \mathrm{mmol}}{5 \times 0.277 \mathrm{mmol} \times \frac{0.05 \mathrm{~mL}}{2.0 \mathrm{~mL}}}=37 \%
\end{aligned}
$$

\section{Electrosynthesis Equipment.}

Synthetic electrochemical experiments were conducted using an IKA Electrasyn 2.0 (part number oo20oo8980) using $5 \mathrm{~mL}$ vials/caps (part number o040003171). Platinum foil electrodes were custom built by cutting and wrapping platinum foil (Alfa Aesar, catalog number 42456, 0.05 mm (o.002 in) thick, Premion ${ }^{\circledR}$, 99.99\% (metals basis)) around a PTFE rectangular support of approximately $8 \mathrm{~mm}$ width by $1 \mathrm{~mm}$ high.

\section{Oxime Derivatization Procedures.}

The enantiomeric excess of 2-ethynylglyceraldehyde was determined following benzyloxyamine derivatization and chromatographic analysis. ${ }^{[3]}$ To the solution of aldehyde (approx. $\left.5 \mu \mathrm{mol}\right)$ in water $(20 \mu \mathrm{L}), 250 \mathrm{mM}$ benzyloxyamine hydrochloride solution ( $80 \mu \mathrm{L}, 20 \mu \mathrm{mmol})$ was added. The reaction was incubated at $30{ }^{\circ} \mathrm{C}$ for $1 \mathrm{~h}$. The reaction mixture was diluted with $150 \mu \mathrm{L}$ acetonitrile, filtered and analyzed by chiral SFC on a chiral stationary phase (CHIRALPAK AD-3 column).

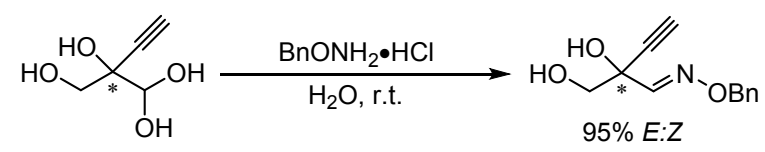

\section{Bioelectrosynthesis of $(R)$-2-ethynylglyceraldehyde from 2-ethynylglycerol.}

Standard procedure using (ferrocenylmethyl)trimethylammonium chloride as the mediator: $30 \mathrm{mg}$ CFE GALO-104 was dissolved in $1 \mathrm{~mL} 1 \mathrm{mM} \mathrm{CuSO}$ solution; $20 \mathrm{mg}$ Bovine catalase was dissolved in $1 \mathrm{~mL} \mathrm{H}_{2} \mathrm{O} ; 40 \mathrm{mg}$ Anti-foam 204 was dissolved in $2 \mathrm{~mL} \mathrm{H}_{2} \mathrm{O}$. To a $5 \mathrm{~mL}$ reaction vial for Electrasyn was added a PTFE coated stir bar, $0.5 \mathrm{~mL}$ $\mathrm{H}_{2} \mathrm{O}$, o.6 mL 1.o M 2-ethynylglycerol solution ( $0.6 \mathrm{mmol}$, in $0.56 \mathrm{M}$ sodium phosphate $\mathrm{pH} 7$ buffer), $0.4 \mathrm{~mL}$ GALO104 solution (12.0 $\mathrm{mg}, \quad 17 \quad \mathrm{wt} \%), \quad 0.5 \quad \mathrm{~mL}$ catalase solution (10.0 $\mathrm{mg}, \quad 14 \quad \mathrm{wt} \%), \quad 8.8 \quad \mathrm{mg}$ (ferrocenylmethyl)trimethylammonium chloride ( $0.03 \mathrm{mmol}, 5 \mathrm{~mol} \%$ ) and $20 \mu \mathrm{L}$ anti-foam 204 solution. The air is bubbled into the solution through Teflon tube. Platinum foil electrodes as both cathode and anode were connected to the Electrasyn vial cap, and the Electrasyn vial cap was connected to the Electrasyn 2.0. The reaction mixture was electrolyzed under a constant voltage of $0.85 \mathrm{~V}$ accompanied by magnetic stirring (80o rpm). The reaction mixture was then filtered. $50 \mu \mathrm{L}$ filtrate was sampled and mixed with $0.5 \mathrm{~mL}$ of maleic acid in $\mathrm{D}_{2} \mathrm{O}(0.5 \mathrm{wt} \%)$ for quantitative ${ }^{1} \mathrm{H}$ NMR spectroscopy to determine assay yield, and $20 \mu \mathrm{L}$ filtrate was subjected to oxime derivatization for chiral SFC analysis to determine ee: $46 \%$ assay yield, $67 \%$ conversion, $90 \%$ ee. ${ }^{1} \mathrm{H}$ NMR $\left(500 \mathrm{MHz}, \mathrm{D}_{2} \mathrm{O}\right.$ with 0.5 wt\% maleic acid): $\delta 4.92(\mathrm{~s}, 1 \mathrm{H}), 3.67(\mathrm{~d}, J=11.7 \mathrm{~Hz}, 1 \mathrm{H}), 3.63(\mathrm{~d}, J=11.7 \mathrm{~Hz}, 1 \mathrm{H}), 2.82(\mathrm{~s}, 1 \mathrm{H}) \mathrm{ppm}$.

Bioelectrosynthesis of $(R)$-2-ethynylglyceraldehyde from 2-ethynylglycerol: conditions for control experiments. 1) In the absence of the GALO-104. The experimental and analytical procedure was the same with the standard procedure above, except $0.4 \mathrm{~mL}_{1} \mathrm{mM} \mathrm{CuSO}_{4}$ solution was added instead of GALO-104 solution. 2) In 
the absence of mediator. The experimental procedure was the same with the general procedure above, except no mediator was added. 3) In the absence of copper. The experimental and analytical procedure was the same with the standard procedure above, except $0.4 \mathrm{~mL} \mathrm{GALO-104}$ in water (30 $\mathrm{mg} / \mathrm{mL}$ ) was added instead of GALO-104 in $1 \mathrm{mM}$ $\mathrm{CuSO}_{4}$ solution. 4) In the absence of catalase. The experimental and analytical procedure was the same with the standard procedure above, except $0.5 \mathrm{~mL}$ water was added instead of catalase solution. 5) In the absence of electricity. The experimental and analytical procedure was the same with the standard procedure above, except the reaction mixture was NOT electrolyzed, but allowed to stir at room temperature for $16 \mathrm{~h}$. 6) In the absence of the air. $30 \mathrm{mg}$ CFE GALO-104 was dissolved in $1 \mathrm{~mL} 1 \mathrm{mM} \mathrm{CuSO}_{4}$ solution in the air, degassed by bubbling $N_{2}$ gas for 5 min and then transferred to a $\mathrm{N}_{2}$-filled glovebox. All other stock solutions were prepared under $\mathrm{N}_{2}$ atmosphere in the glovebox, using degassed water or buffer solution. The experimental and analytical procedure was the same with the standard procedure above, except the reaction mixture was prepared in a glovebox. The results of assay yield, conversion and ee were listed in Table 2 in the manuscript.

Bioelectrosynthesis of $(\boldsymbol{R})$-2-ethynylglyceraldehyde from 2-ethynylglycerol: voltage dependence. The experimental and analytical procedure was the same with the standard procedure above, except the constant voltage applied to the electrolytic cell was varied: $0.75 \mathrm{~V}, 0.8 \mathrm{~V}, 0.85 \mathrm{~V}, 0.9 \mathrm{~V}, 0.95 \mathrm{~V}$ or $1.0 \mathrm{~V}$. The results of assay yield and conversion were listed in Table $\mathrm{S} 1$ as well as Figure 4 in the manuscript.

Bioelectrosynthesis of $(R)$-2-ethynylglyceraldehyde from 2-ethynylglycerol: electrolysis in insufficient time. The experimental and analytical procedure was the same with the standard procedure above, except the reaction mixture was electrolyzed for only $1 \mathrm{~h}$ under a constant voltage of $0.85 \mathrm{~V}$ accompanied by magnetic stirring (8oo rpm), then the electricity was turned off but the reaction mixture was stirred for another $15 \mathrm{~h}$. The conversion (16\%) was determined by quantitative ${ }^{1} H$ NMR spectroscopy.

Table S1: Results for bioelectrocatalytic oxidation of 2-ethynylglycerol under various voltages.

\begin{tabular}{lllll} 
Voltage & $\boldsymbol{A} \boldsymbol{Y}$ & conversion & HCOOH & Acid \\
\hline $0.75 \mathrm{~V}$ & $25 \%$ & $32 \%$ & $0 \%$ & $0 \%$ \\
$0.8 \mathrm{~V}$ & $42 \%$ & $52 \%$ & $2 \%$ & $0 \%$ \\
$0.85 \mathrm{~V}$ & $46 \%$ & $67 \%$ & $3 \%$ & $3 \%$ \\
$0.9 \mathrm{~V}$ & $40 \%$ & $66 \%$ & $7 \%$ & $4 \%$ \\
$0.95 \mathrm{~V}$ & $46 \%$ & $73 \%$ & $6 \%$ & $5 \%$ \\
$1.0 \mathrm{~V}$ & $42 \%$ & $86 \%$ & $9 \%$ & $8 \%$
\end{tabular}

Bioelectrosynthesis of $(R)$-2-ethynylglyceraldehyde from 2-ethynylglycerol using GALO-104 and various mediators. $30 \mathrm{mg}$ CFE GALO-104 was dissolved in $1 \mathrm{~mL} 1 \mathrm{mM} \mathrm{CuSO}_{4}$ solution; $20 \mathrm{mg}$ Bovine catalase was dissolved in $1 \mathrm{~mL} \mathrm{H}_{2} \mathrm{O}$; $40 \mathrm{mg}$ Anti-foam 204 was dissolved in $2 \mathrm{~mL} \mathrm{H}_{2} \mathrm{O}$. To a $5 \mathrm{~mL}$ reaction vial for Electrasyn was added a PTFE coated stir bar, $0.5 \mathrm{~mL} \mathrm{H}_{2} \mathrm{O}$, o.6 mL 1.o M 2-ethynylglycerol solution ( $0.6 \mathrm{mmol}$, in $0.56 \mathrm{M}$ sodium phosphate $\mathrm{pH} 7$ buffer), $0.4 \mathrm{~mL}$ GALO-104 solution (12.0 mg, $17 \mathrm{wt} \%$ ), $0.5 \mathrm{~mL}$ catalase solution (10.0 $\mathrm{mg}, 14 \mathrm{wt} \%$ ), mediator ( $0.03 \mathrm{mmol}$ ) and finally $20 \mu \mathrm{L}$ anti-foam 204 solution. The air is bubbled into the solution through Teflon tube. Platinum foil electrodes as both cathode and anode were connected to the Electrasyn vial cap, and the Electrasyn vial cap was connected to the Electrasyn 2.o. The reaction mixture was electrolyzed under a constant current of 0.4 $\mathrm{mA}$ for $16 \mathrm{~h}$ accompanied by magnetic stirring ( $800 \mathrm{rpm}$ ). The reaction mixture was then filtered. $50 \mu \mathrm{L}$ filtrate was sampled and mixed with $0.5 \mathrm{~mL}$ of maleic acid in $\mathrm{D}_{2} \mathrm{O}$ (0.25 wt\% or $0.5 \mathrm{wt} \%$ ) for quantitative ${ }^{1} \mathrm{H}$ NMR spectroscopy to determine assay yield, and $20 \mu \mathrm{L}$ filtrate was subjected to oxime derivatization for chiral SFC analysis to determine ee. The results of assay yield, conversion and ee when different mediators were used were listed in Table 3 in the manuscript.

Non-electrolytic, biocatalytic synthesis of $(R)$-2-ethynylglyceraldehyde from 2-ethynylglycerol using GALO-104 and HRP or alternative chemical oxidants. $30 \mathrm{mg}$ GALO-104 was dissolved in $1 \mathrm{~mL} 1 \mathrm{mM} \mathrm{CuSO}_{4}$

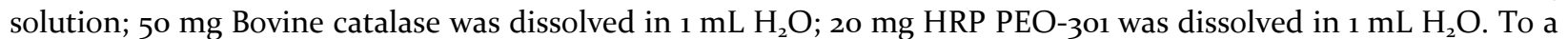
96-well screening plate was added $120 \mu \mathrm{L} \mathrm{H}_{2} \mathrm{O}, 120 \mu \mathrm{L}$ 1.0 M 2-ethynylglycerol solution (o.12 mmol, in $0.56 \mathrm{M}$ sodium phosphate $\mathrm{pH} 7$ buffer), $80 \mu \mathrm{L}$ GALO-104 solution ( $2.4 \mathrm{mg}$, $17 \mathrm{wt} \%), 40 \mu \mathrm{L}$ catalase solution $(2.0 \mathrm{mg}, 14 \mathrm{wt} \%), 40 \mu \mathrm{L}$ HRP solution (o.8 mg, $6 \mathrm{wt} \%$ ) or alternative chemical oxidant (Bobbitt's salt, 4-AcNH-TEMPO, $12.0 \mu \mathrm{mol}$, $10 \mathrm{~mol} \%$; 
or $\mathrm{K}_{2} \mathrm{IrCl}_{6}, 1.2 \mu \mathrm{mol}, 1 \mathrm{~mol} \%$; or $12.0 \mu \mathrm{mol}, 10 \mathrm{~mol} \%$ ). The plate was sealed with a gas-permeable membrane, incubated with vigorous shaking (80o rpm). After $16 \mathrm{~h}$, the reaction mixture was centrifuged. $50 \mu \mathrm{L}$ supernatant was sampled and mixed with $0.5 \mathrm{~mL}$ of maleic acid in $\mathrm{D}_{2} \mathrm{O}$ (0.25 wt\% or $0.5 \mathrm{wt} \%$ ) for quantitative ${ }^{1} \mathrm{H}$ NMR spectroscopy to determine assay yield, and $20 \mu \mathrm{L}$ filtrate was subjected to oxime derivatization for chiral SFC analysis to determine ee. The results of assay yield, conversion and ee when different mediators were used were listed in Table S2.

Table S2: Results for biocatalytic oxidation of 2-ethynylglycerol using HRP or alternative chemical oxidants.

\begin{tabular}{lllllll} 
Oxidants & Loading & $\boldsymbol{A Y}$ & conversion & HCOOH & Acid & ee \\
\hline $\mathrm{HRP}$ & $6 \mathrm{wt} \%$ & $50 \%$ & $72 \%$ & $0 \%$ & $1 \%$ & $90 \%$ \\
Bobbitt's salt & $10 \mathrm{~mol} \%$ & $3 \%$ & $5 \%$ & $0 \%$ & $0 \%$ & N.D. $^{a}$ \\
$4-\mathrm{AcNH}-\mathrm{TEMPO}$ & $10 \mathrm{~mol} \%$ & $6 \%$ & $6 \%$ & $0 \%$ & $1 \%$ & N.D. $^{a}$ \\
$\mathrm{~K}_{2} \mathrm{IrCl}$ & $1 \mathrm{~mol} \%$ & $5 \%$ & $7 \%$ & $0 \%$ & $0 \%$ & N.D. $^{a}$ \\
$\mathrm{~K}_{2} \mathrm{IrCl}$ & $10 \mathrm{~mol} \%$ & $8 \%$ & $10 \%$ & $0 \%$ & $1 \%$ & $75 \%$
\end{tabular}

a. N.D. = not determined, due to low conversion and low peak intensity on SFC traces.

Table S3: Results for biocatalytic oxidation of benzyl alcohol derivatives or cinnamyl alcohol using different GOase variants.

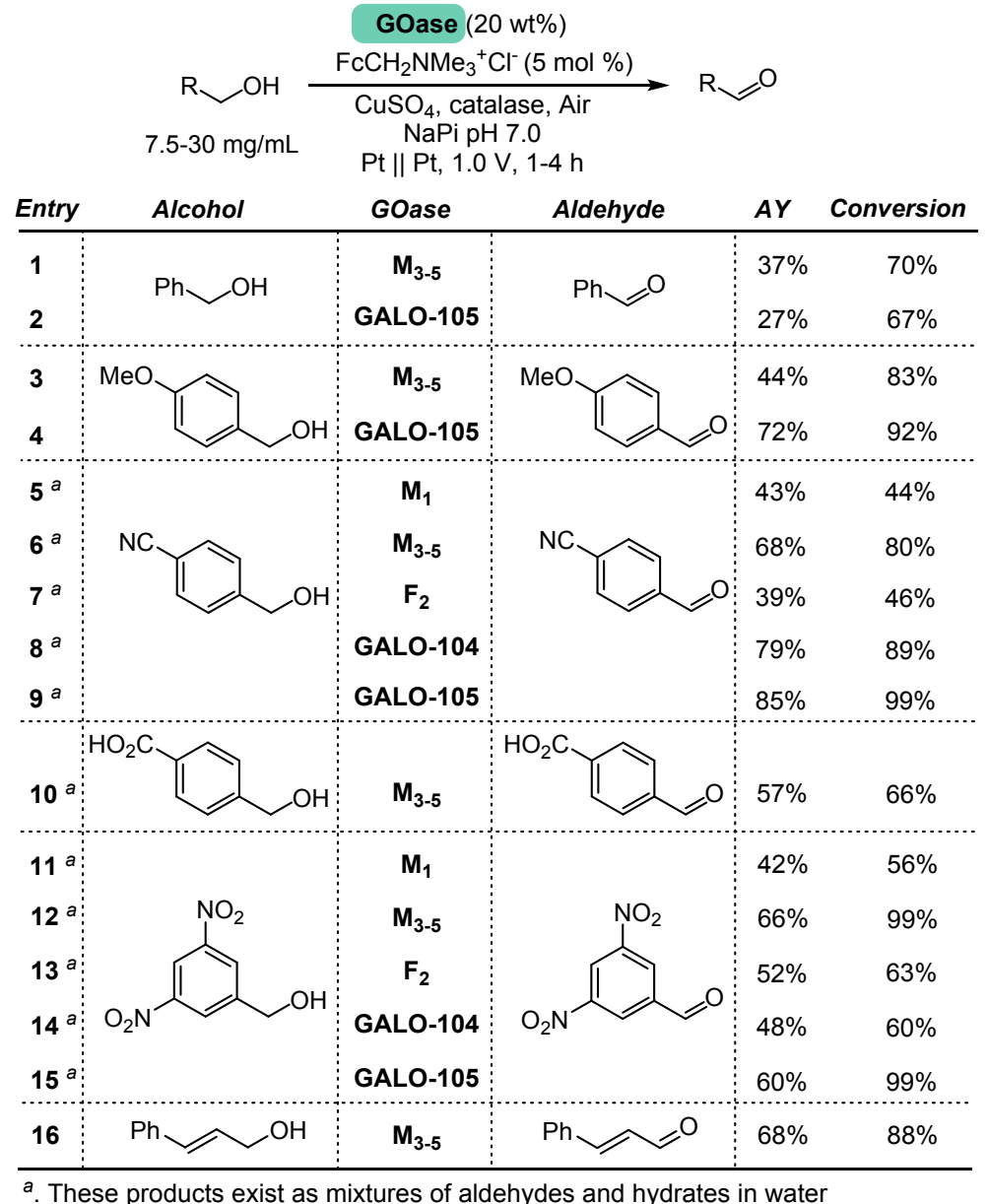

${ }^{a}$. These products exist as mixtures of aldehydes and hydrates in water 


\section{General procedure for bioelectrosynthesis of aldehydes from benzyl alcohol derivatives or cinnamyl alcohol using different GOase variants.}

$15 \mathrm{mg}$ CFE GOase was dissolved in $1 \mathrm{~mL} 1 \mathrm{mM} \mathrm{CuSO}_{4}$ solution; $15 \mathrm{mg}$ Bovine catalase was dissolved in $2 \mathrm{~mL}_{2} \mathrm{O}$; $40 \mathrm{mg}$ Anti-foam 204 was dissolved in $2 \mathrm{~mL} \mathrm{H}_{2} \mathrm{O}$. To a $5 \mathrm{~mL}$ reaction vial for Electrasyn was added a PTFE coated stir bar, $1.0 \mathrm{~mL} \mathrm{H}_{2} \mathrm{O}, 0.34 \mathrm{~mL} 1 \mathrm{M}$ sodium phosphate $\mathrm{pH} 7$ buffer, alcohol (15.0 mg), $0.2 \mathrm{~mL}$ GOase solution (3.0 mg, $20 \mathrm{wt} \%$ ), $0.1 \mathrm{~mL}$ catalase solution ( $0.75 \mathrm{mg}, 5 \mathrm{wt} \%$ ), (ferrocenylmethyl)trimethylammonium chloride ( $5 \mathrm{~mol} \%$ to the alcohol) and finally $20 \mu \mathrm{L}$ anti-foam 204 solution; $0.2 \mathrm{~mL}$ of DMSO was added to the reaction mixture containing cinnamyl alcohol. The air is bubbled into the solution through Teflon tube. Platinum foil electrodes as both cathode and anode were connected to the Electrasyn vial cap, and the Electrasyn vial cap was connected to the Electrasyn 2.0. The reaction mixture was electrolyzed under a constant voltage of $1.0 \mathrm{~V}$ for $16 \mathrm{~h}$ accompanied by magnetic stirring ( $800 \mathrm{rpm}$ ). The reaction mixture was then filtered. $50 \mu \mathrm{L}$ filtrate was sampled and mixed with $0.5 \mathrm{~mL}$ of maleic acid in $\mathrm{D}_{2} \mathrm{O}$ ( $0.25 \mathrm{wt} \%$ ) for quantitative ${ }^{1} \mathrm{H}$ NMR spectroscopy to determine assay yield. The results of assay yield and conversion when different GOase variants were used were listed in Table S3. ${ }^{1} \mathrm{H}$ NMR spectra are shown in Figures S3-S16. Benzaldehyde (entry 1) ${ }^{[6]}$, 4-anisaldehyde (entry 2) $)^{[6]}$, 4 -formyl benzonitrile (entry 3), ${ }^{[7]} 4^{-}$ formylbenzoic acid (entry 4), ${ }^{[8]} 3,5$-dinitrobenzaldehyde (entry 5) ${ }^{[9]}$ and cinnamaldehyde (entry 6) ${ }^{[0]}$ were assigned by comparison with literature data.

Table S4: Results for biocatalytic oxidation of aliphalic poly-ols using different GOase variants.

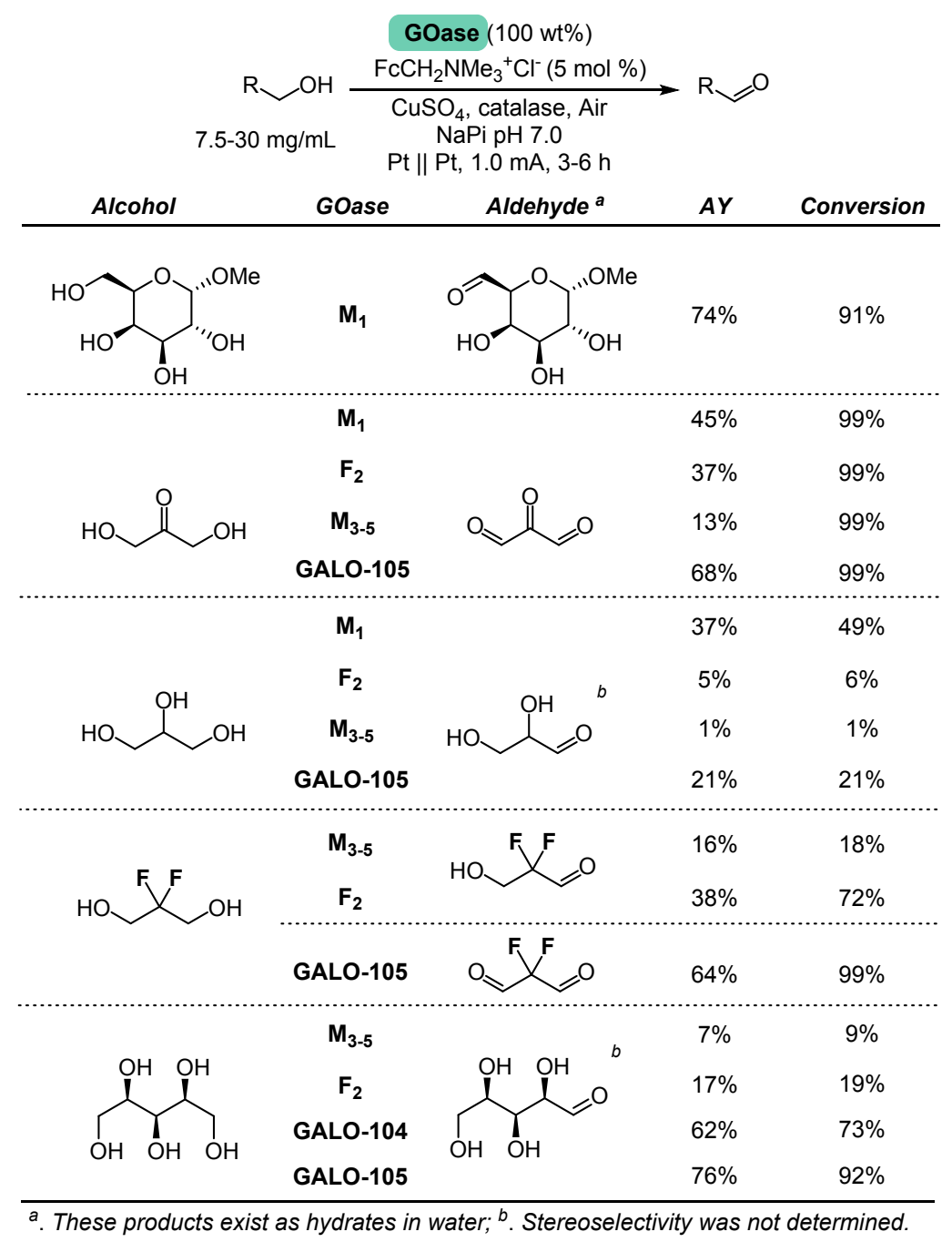

Isolation and purification of 4 -formyl benzonitrile and 3,5-dinitrobenzaldehyde from the reaction mixture. After the electrolysis, the reaction mixture was diluted with $2 \mathrm{~mL} 50 \mathrm{mM} \mathrm{HCl}$ and allowed to stir at 
room temperature for overnight. The mixture was extracted with $2 \mathrm{~mL}$ methyl tert-butyl ether for three times. The combined organic phase was combined, washed with $2 \mathrm{~mL}$ water and $2 \mathrm{~mL}$ brine, then dried over anhydrous sodium sulfate. Volatile materials were removed under reduced pressure, and the resulting residue was dried under vacuum for 30 minutes to afford the aldehyde derivatives in pure form, as indicated by their ${ }^{1} \mathrm{H}$ NMR spectra, and thus no further purification step was required. The NMR spectra of both aldehyde derivatives match the previously published spectra. ${ }^{[7,9]]}$ 4-Formylbenzonitrile: off-white solid, yield $12.3 \mathrm{mg}(82 \%) ;{ }^{1} \mathrm{H}$ NMR (500 $\left.\mathrm{MHz}, \mathrm{CDCl}_{3}, 25^{\circ} \mathrm{C}\right): \delta=10.12(\mathrm{~s}, 1 \mathrm{H}, \mathrm{CHO}), 8.02\left(\mathrm{~d}, 3 J_{\mathrm{HH}}=8.4 \mathrm{~Hz}, 2 \mathrm{H}, \mathrm{C}_{6} H_{4}\right), 7.87\left(\mathrm{~d}, 3 J_{\mathrm{HH}}=8.3 \mathrm{~Hz}, 2 \mathrm{H}, \mathrm{C}_{6} H_{4}\right)$ ppm. 3,5-Dinitrobenzaldehyde: yellow solid, yield $\left.9.9 \mathrm{mg}(66 \%) ;{ }^{1} \mathrm{H} \mathrm{NMR} \mathrm{(500} \mathrm{MHz}, \mathrm{CDCl}_{3}, 2{ }^{\circ} \mathrm{C}\right): \delta=10.20(\mathrm{~s}$, $1 \mathrm{H}, \mathrm{CHO}), 9.27\left(\mathrm{t}, 3 J_{\mathrm{HH}}=4.0 \mathrm{~Hz}, 1 \mathrm{H}, \mathrm{C}_{6} \mathrm{H}_{3}\right), 9.04\left(\mathrm{~d}, 3 J_{\mathrm{HH}}=4.2 \mathrm{~Hz}, 2 \mathrm{H}, \mathrm{C}_{6} \mathrm{H}_{3}\right) \mathrm{ppm}$.

\section{General procedure for bioelectrosynthesis of aldehydes from aliphalic poly-ols using different GOase variants.}

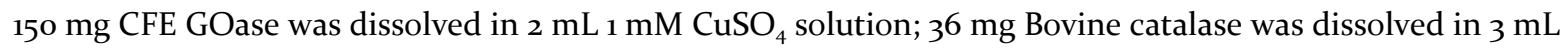
$\mathrm{H}_{2} \mathrm{O} ; 40 \mathrm{mg}$ Anti-foam 204 was dissolved in $2 \mathrm{~mL} \mathrm{H}_{2} \mathrm{O}$. To a $5 \mathrm{~mL}$ reaction vial for Electrasyn was added a PTFE coated stir bar, o.8 $\mathrm{mL} \mathrm{H}_{2} \mathrm{O}, 0.34 \mathrm{~mL}$ 1 M sodium phosphate $\mathrm{pH} 7$ buffer, alcohol (30.o mg), $0.4 \mathrm{~mL}$ GOase solution (30.0 mg, $100 \mathrm{wt} \%$ ), $0.5 \mathrm{~mL}$ catalase solution (6.0 $\mathrm{mg}, 20 \mathrm{wt} \%)$, (ferrocenylmethyl)trimethylammonium chloride ( $5 \mathrm{~mol} \%$ to the alcohol) and finally $20 \mu \mathrm{L}$ anti-foam 204 solution. The air is bubbled into the solution through Teflon tube. Platinum foil electrodes as both cathode and anode were connected to the Electrasyn vial cap, and the Electrasyn vial cap was connected to the Electrasyn 2.0. The reaction mixture was electrolyzed under a constant current of $1.0 \mathrm{~mA}$ for $16 \mathrm{~h}$ accompanied by magnetic stirring (80o rpm). The reaction mixture was then filtered. $50 \mu \mathrm{L}$ filtrate was sampled and mixed with $500 \mu \mathrm{L}$ of $\mathrm{D}_{2} \mathrm{O}$ containing $0.25 \mathrm{wt} \%$ of maleic acid for quantitative ${ }^{1} \mathrm{H}$ NMR spectroscopy to determine assay yield. The results of assay yield and conversion when different GOase variants were used were listed in Table S4. ${ }^{~} \mathrm{H}$ NMR spectra are shown in Figures S17-S26. Methyl$\alpha$-galacto-hexodialdo-1,5-pyranoside ${ }^{[1]}$, glyceraldehyde ${ }^{[12]}$ and xylose ${ }^{\left[{ }_{13}\right]}$ were assigned by comparison with literature data. 2,2-difluoro-3-hydroxypropanal (hydrate in $\mathrm{D}_{2} \mathrm{O}$ ): NMR yield $38 \%$; ${ }^{\mathrm{H}} \mathrm{H}$ NMR $\left(500 \mathrm{MHz}, \mathrm{D}_{2} \mathrm{O}, 25\right.$ $\left.{ }^{\circ} \mathrm{C}\right): \delta=5.14\left(\mathrm{t},{ }_{3} J_{\mathrm{FH}}=7.9 \mathrm{~Hz}, 1 \mathrm{H}, \mathrm{CH}\right), 3.84\left(\mathrm{t}, 3_{\mathrm{FH}}=14.8 \mathrm{~Hz}, 2 \mathrm{H}, \mathrm{CH}_{2}\right) \mathrm{ppm}$. Difluoromalonaldehyde (hydrate in $\left.\mathrm{D}_{2} \mathrm{O}\right)$ : NMR yield $64 \%$; ${ }^{1} \mathrm{H}$ NMR $\left(500 \mathrm{MHz}, \mathrm{D}_{2} \mathrm{O}, 25^{\circ} \mathrm{C}\right): \delta=5.20\left(\mathrm{t}, 3_{\mathrm{FH}}=8.5 \mathrm{~Hz}, 2 \mathrm{H}, \mathrm{CH}\right) \mathrm{ppm}$.

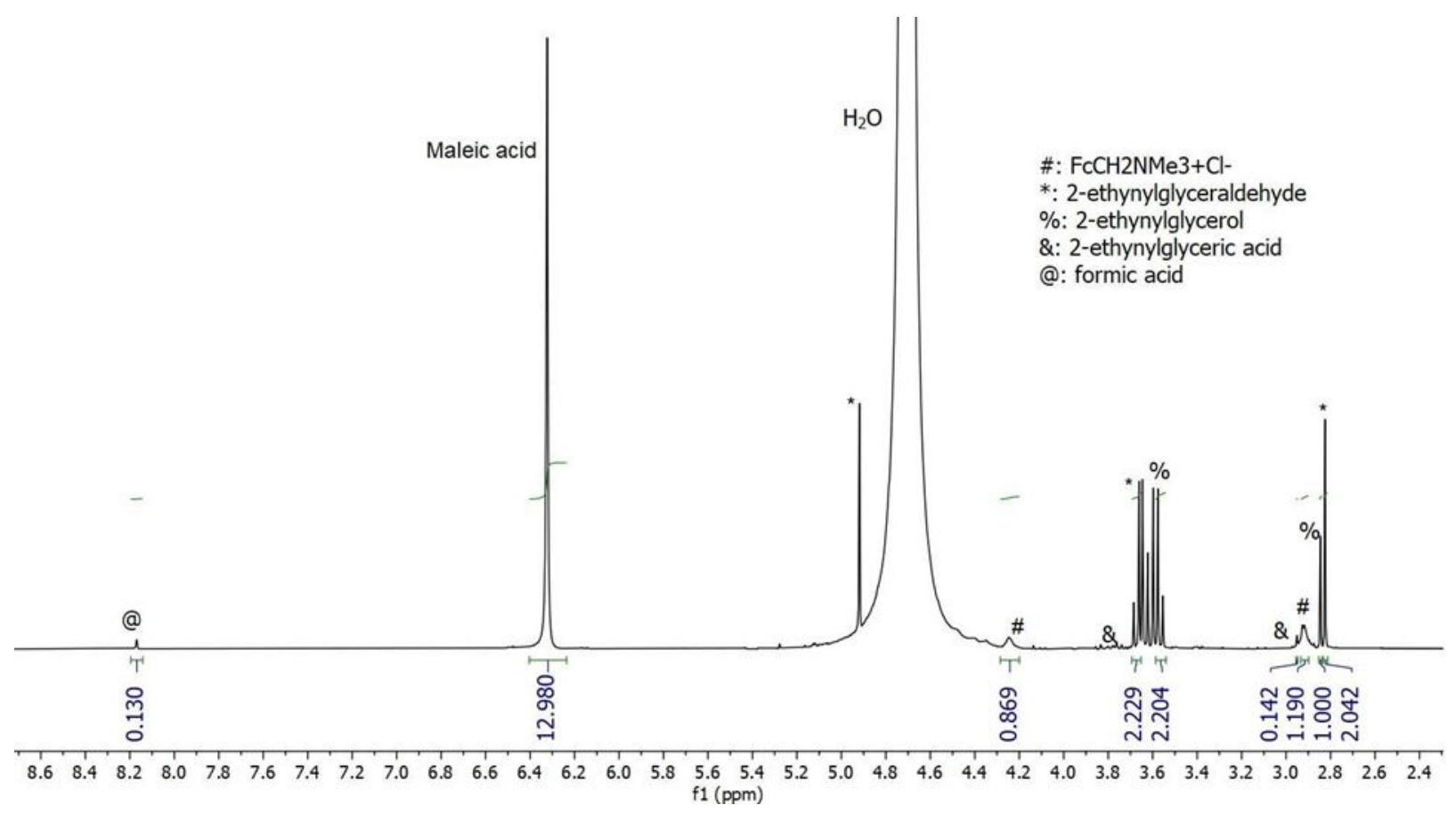


Figure S3: ${ }^{1} \mathrm{H}$ NMR spectrum of the reaction mixture of bioelectrocatalytic oxidation of 2-ethynyl glycerol (Table 2, entry 1; substrate scale: $0.6 \mathrm{mmol}$ ) in $500 \mu \mathrm{L}$ of $\mathrm{D}_{2} \mathrm{O}$ containing $0.5 \mathrm{wt} \%$ of maleic acid ( $298 \mathrm{~K}$ ).

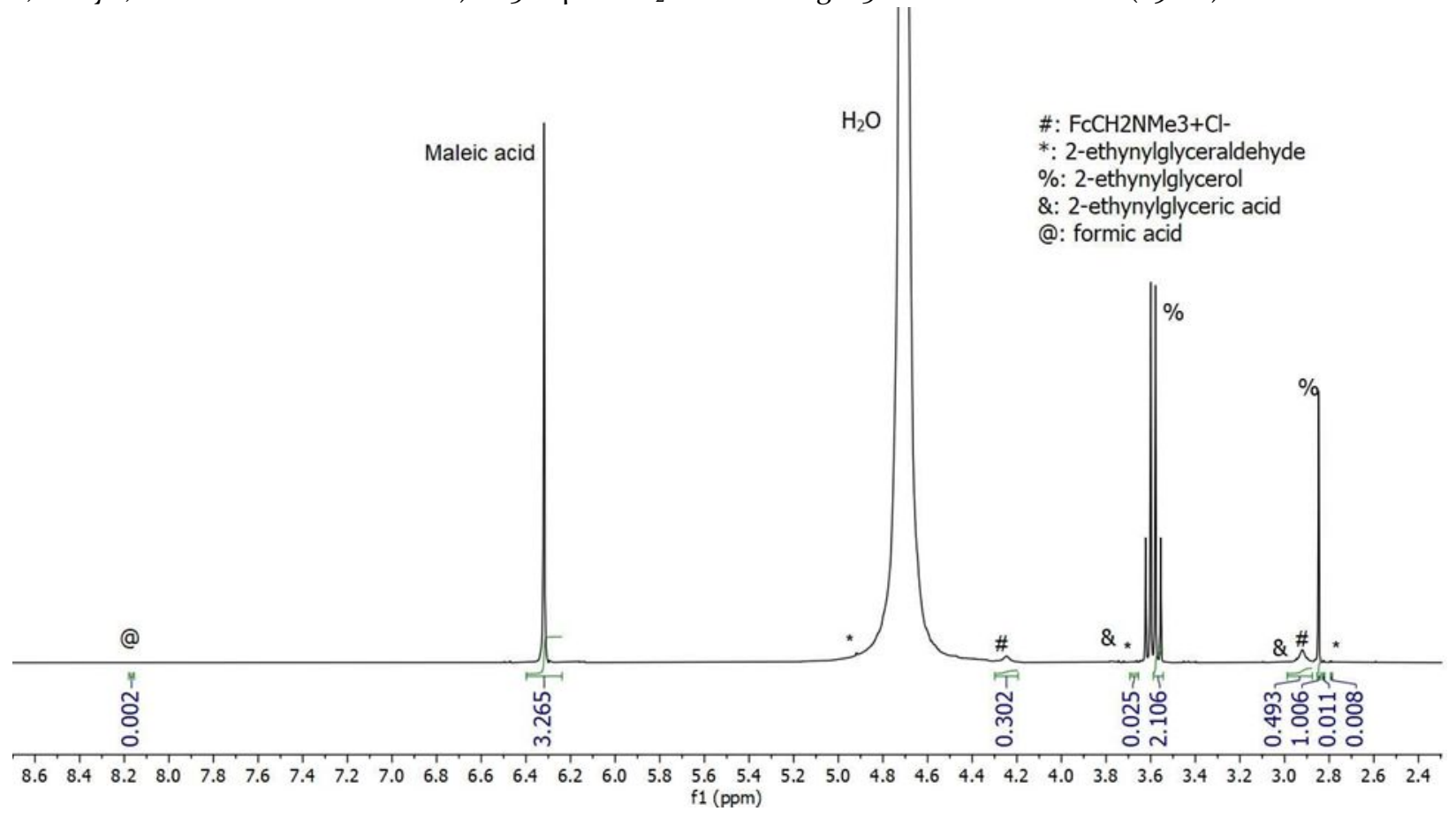

Figure $\mathbf{S}_{\mathbf{4}}$ : ${ }^{1} \mathrm{H}$ NMR spectrum of the reaction mixture of non-electrolytic, biocatalytic oxidation of 2-ethynyl glycerol (Table 2, entry 5; substrate scale: $0.6 \mathrm{mmol}$ ) in $500 \mu \mathrm{L}$ of $\mathrm{D}_{2} \mathrm{O}$ containing $0.5 \mathrm{wt} \%$ of maleic acid (298 K).

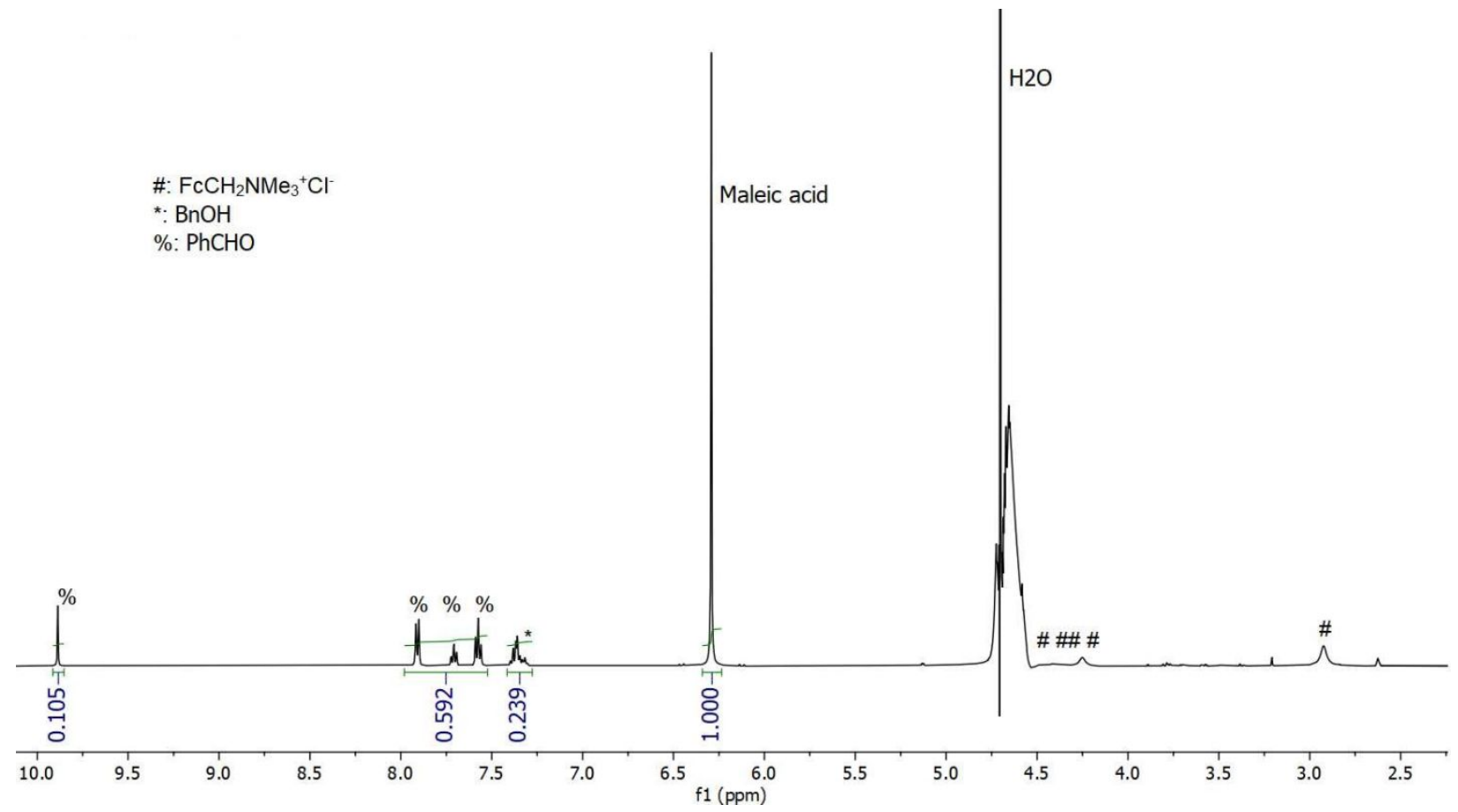

Figure S5: ${ }^{1} \mathrm{H}$ NMR spectrum of the reaction mixture of bioelectrocatalytic oxidation of benzyl alcohol (Table 4, entry 1; substrate scale: $30.0 \mathrm{mg}, 277 \mathrm{mmol})$ in $500 \mu \mathrm{L}$ of $\mathrm{D}_{2} \mathrm{O}$ containing $0.25 \mathrm{wt} \%$ of maleic acid $(298 \mathrm{~K})$. 


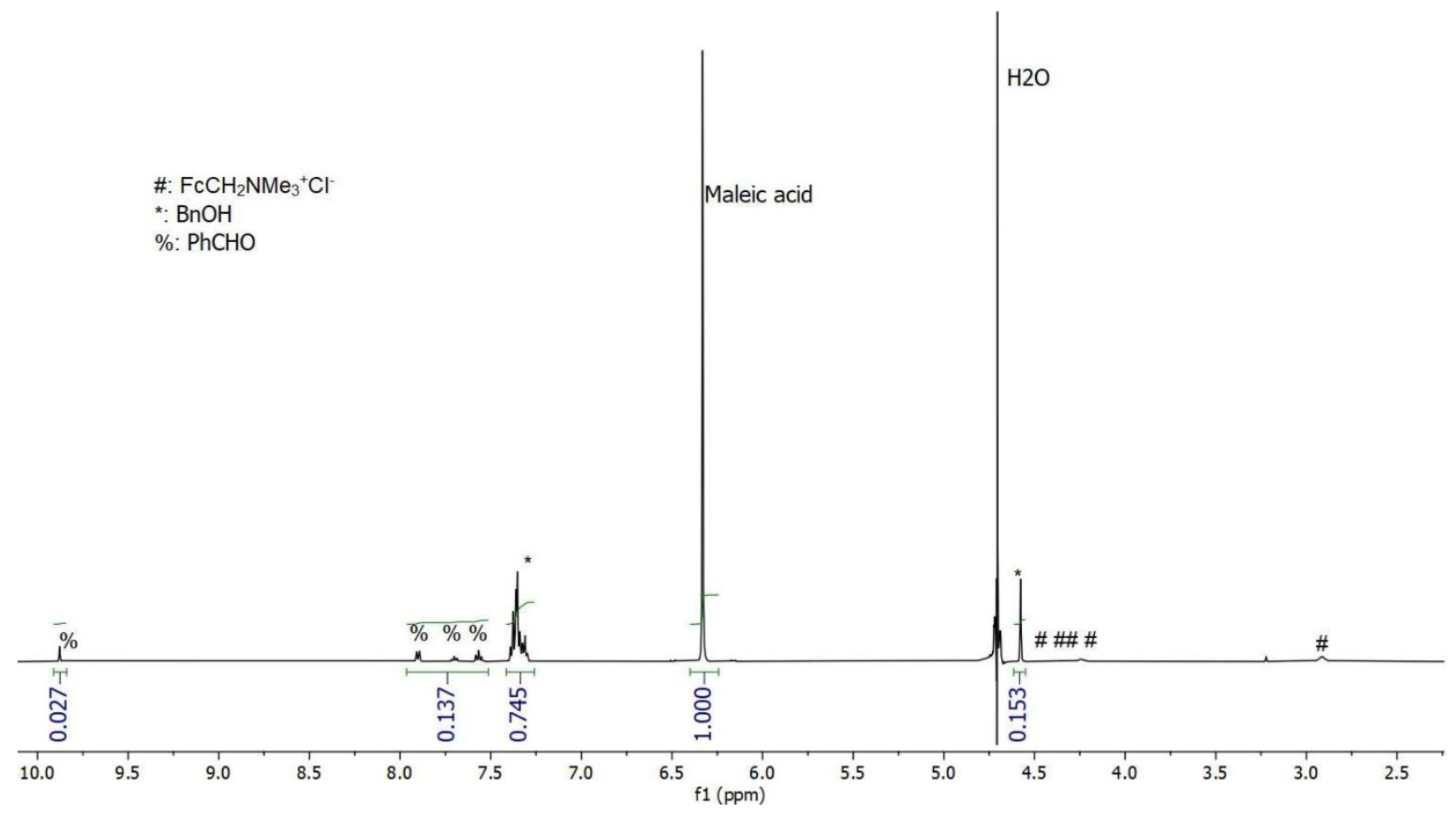

Figure S6: ' $\mathrm{H}$ NMR spectrum of the reaction mixture of non-electrolytic, biocatalytic oxidation of benzyl alcohol (Table 4, entry 1; substrate scale: $30.0 \mathrm{mg}, 277 \mathrm{mmol}$ ) in $500 \mu \mathrm{L}$ of $\mathrm{D}_{2} \mathrm{O}$ containing $0.5 \mathrm{wt} \%$ of maleic acid (298 $\mathrm{K}$ ).

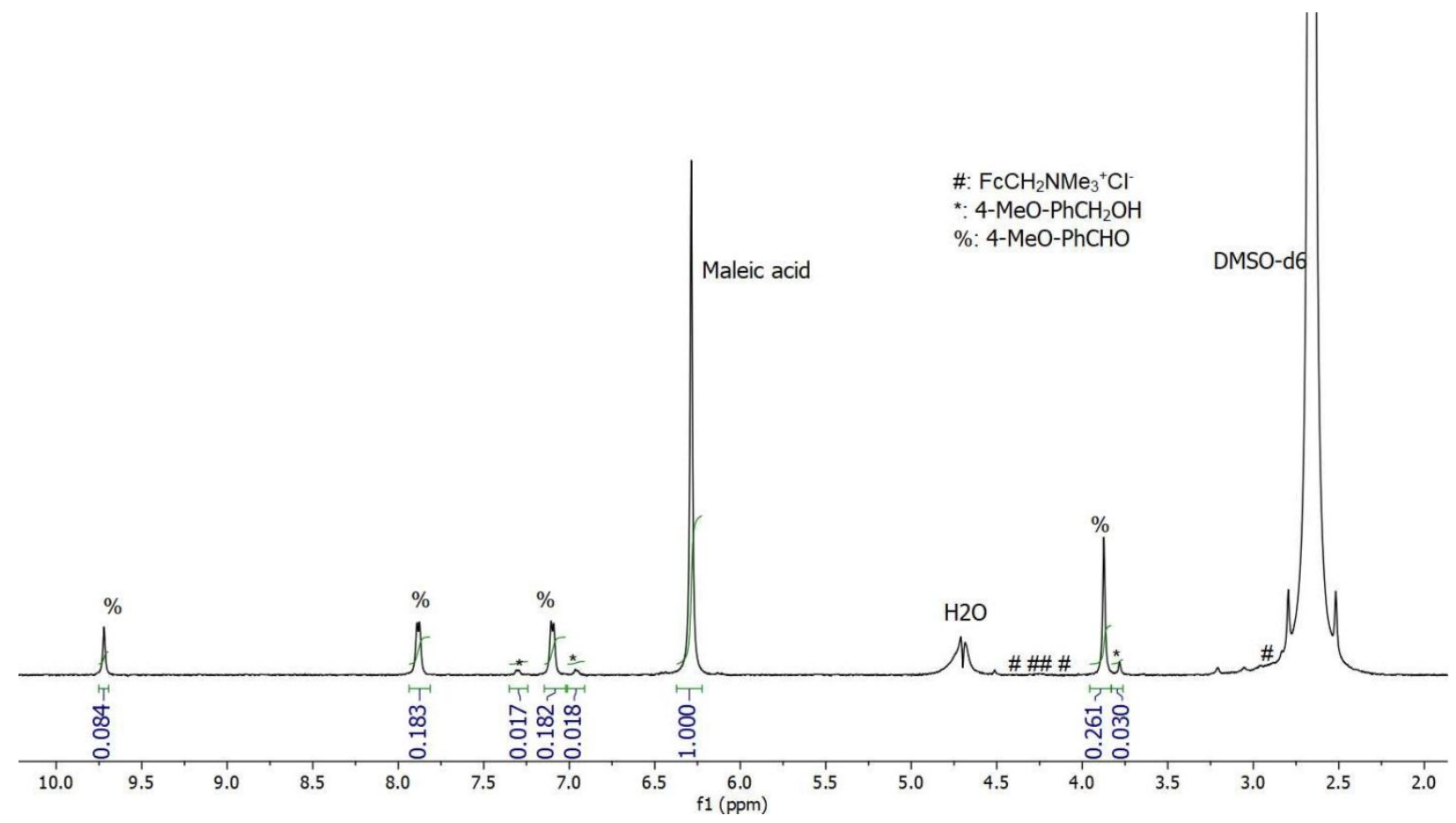

Figure $\mathrm{S}_{7}:{ }^{1} \mathrm{H}$ NMR spectrum of the reaction mixture of bioelectrocatalytic oxidation of 4-methoxybenzyl alcohol (Table 4, entry 2; substrate scale: $15.0 \mathrm{mg}, 109 \mathrm{mmol}$ ) in $500 \mu \mathrm{L}$ of $\mathrm{D}_{2} \mathrm{O}$ containing $0.25 \mathrm{wt} \%$ of maleic acid (298 $\mathrm{K}$ ). 


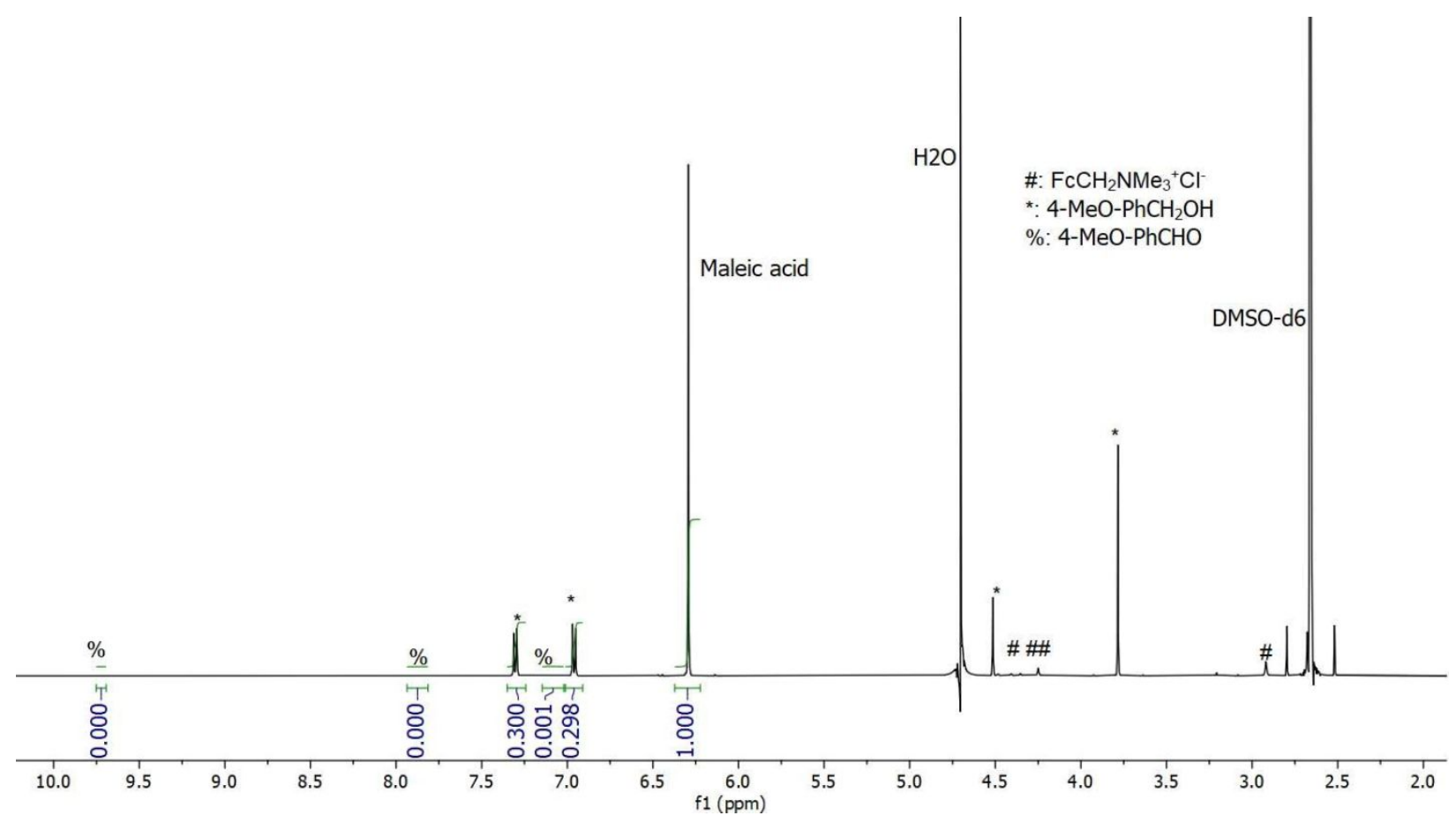

Figure S8: ${ }^{1} \mathrm{H}$ NMR spectrum of the reaction mixture of non-electrolytic, biocatalytic oxidation of 4methoxybenzyl alcohol (Table 4, entry 2; substrate scale: $15.0 \mathrm{mg}$, $109 \mathrm{mmol}$ ) in $500 \mu \mathrm{L}$ of $\mathrm{D}_{2} \mathrm{O}$ containing 0.25 $\mathrm{wt} \%$ of maleic acid $(298 \mathrm{~K})$.

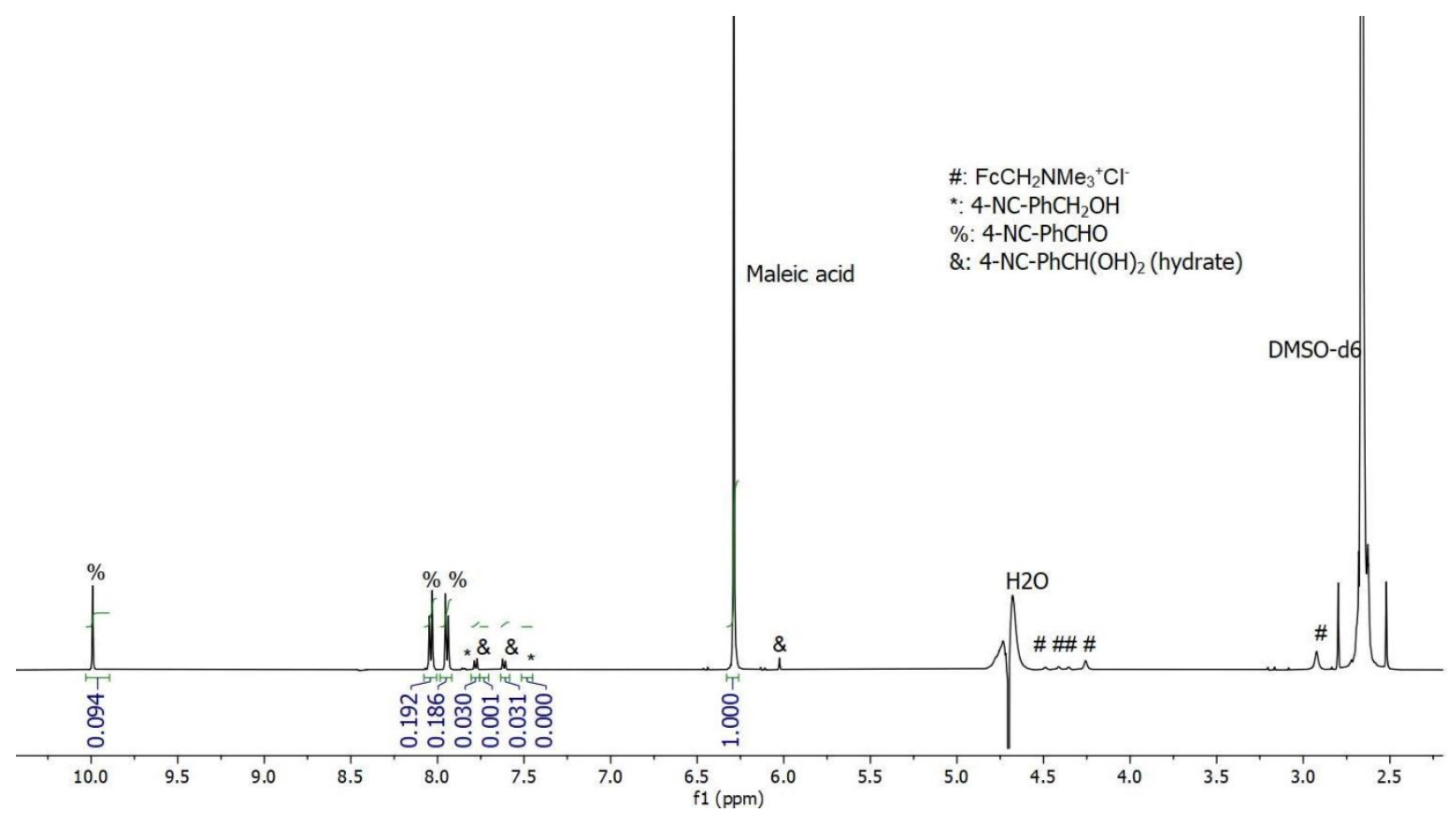

Figure S9: ' ${ }^{H} \mathrm{H}$ NR spectrum of the reaction mixture of bioelectrocatalytic oxidation of 4-cyanobenzyl alcohol (Table 4, entry 3; substrate scale: $15.0 \mathrm{mg}$, $113 \mathrm{mmol}$ ) in $500 \mu \mathrm{L}$ of $\mathrm{D}_{2} \mathrm{O}$ containing $0.25 \mathrm{wt} \%$ of maleic acid (298 $\mathrm{K}$ ). 


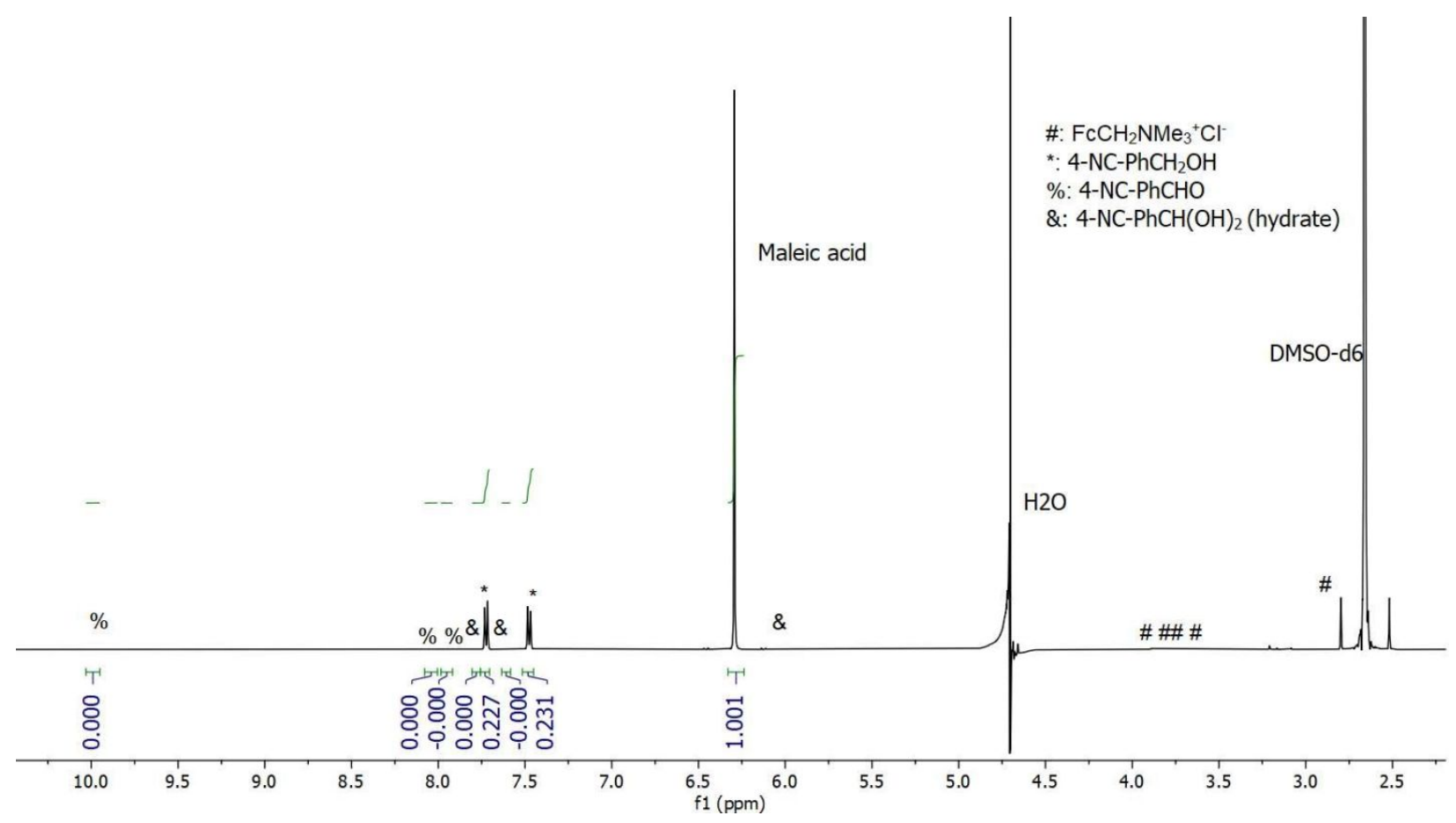

Figure S1o: ${ }^{1} \mathrm{H}$ NMR spectrum of the reaction mixture of non-electrolytic, biocatalytic oxidation of 4-cyanobenzyl alcohol (Table 4, entry 3; substrate scale: $15.0 \mathrm{mg}, 113 \mathrm{mmol}$ ) in $500 \mu \mathrm{L}$ of $\mathrm{D}_{2} \mathrm{O}$ containing $0.25 \mathrm{wt} \%$ of maleic acid $(298 \mathrm{~K})$.

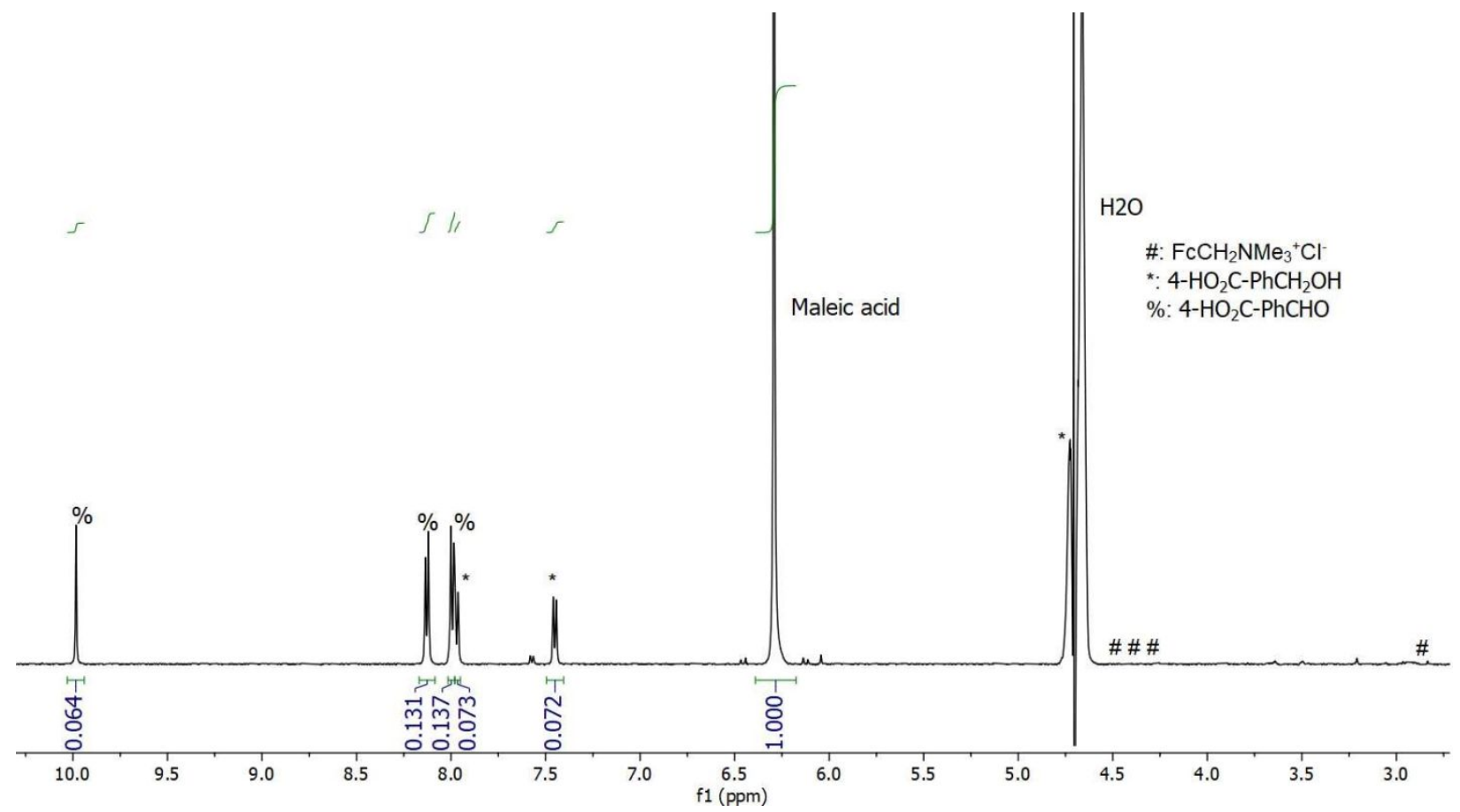

Figure S11: ${ }^{1} \mathrm{H}$ NMR spectrum of the reaction mixture of bioelectrocatalytic oxidation of 4-hydroxymethyl benzoic acid (Table 4, entry 4; substrate scale: $15.0 \mathrm{mg}$, $99 \mathrm{mmol}$ ) in $500 \mu \mathrm{L}$ of $\mathrm{D}_{2} \mathrm{O}$ containing $0.25 \mathrm{wt} \%$ of maleic acid $(298 \mathrm{~K})$. 


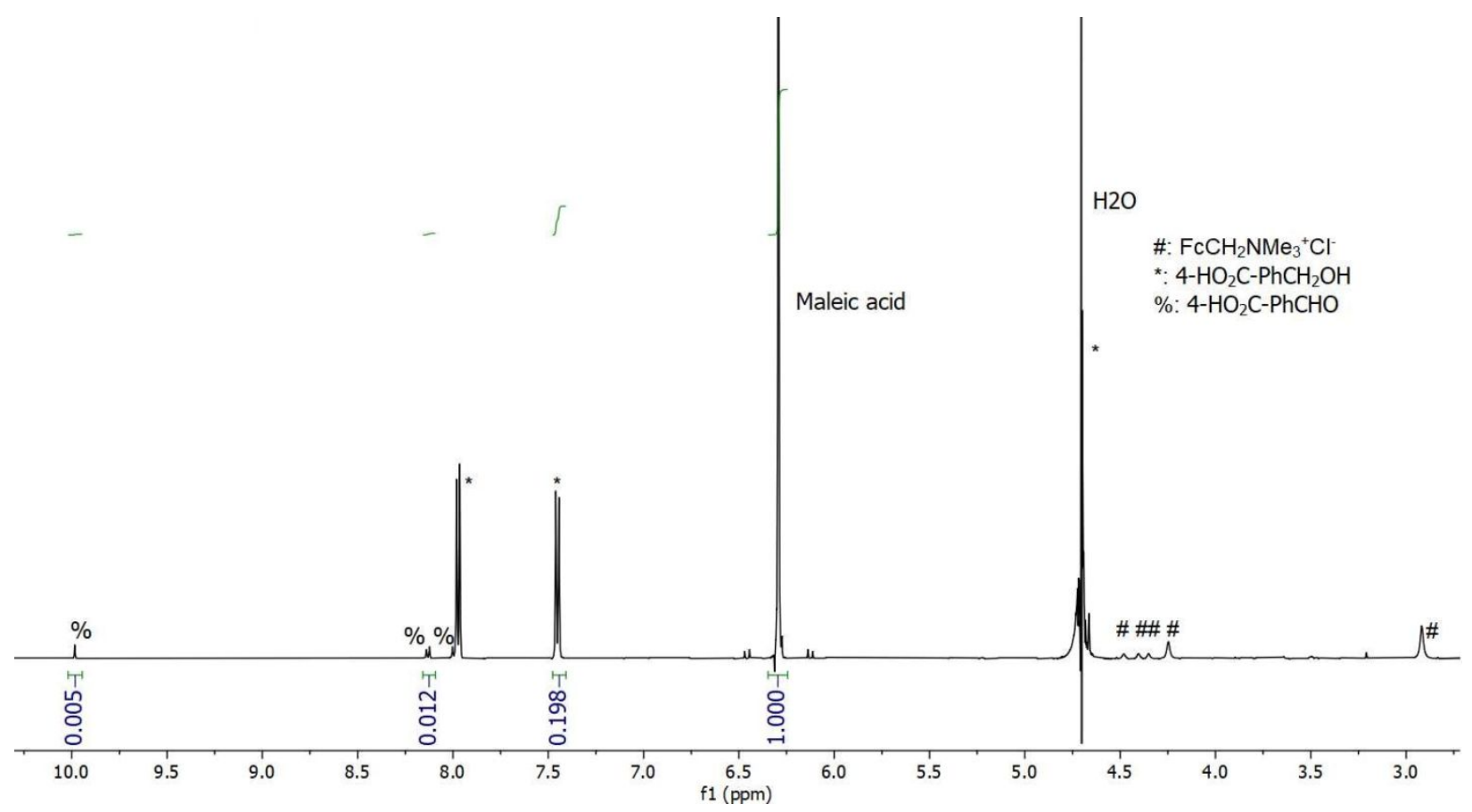

Figure S12: ' $\mathrm{H}$ NMR spectrum of the reaction mixture of non-electrolytic, biocatalytic oxidation of 4hydroxymethyl benzoic acid (Table 4, entry 4; substrate scale: $15.0 \mathrm{mg}$, $99 \mathrm{mmol}$ ) in $500 \mu \mathrm{L}$ of $\mathrm{D}_{2} \mathrm{O}$ containing $0.25 \mathrm{wt} \%$ of maleic acid $(298 \mathrm{~K})$.

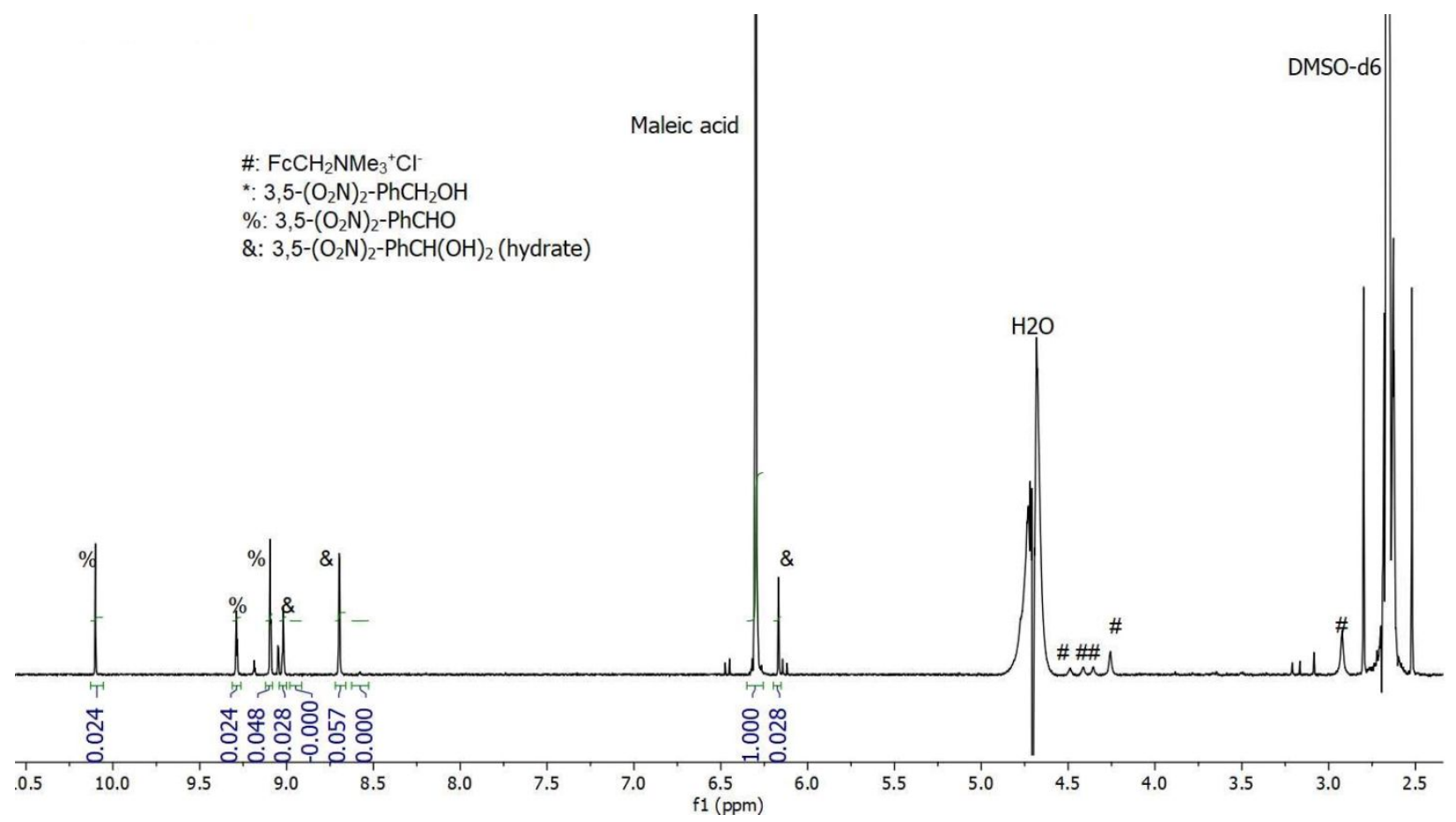

Figure S13: ${ }^{1} \mathrm{H}$ NMR spectrum of the reaction mixture of bioelectrocatalytic oxidation of 3,5-dinitrobenzyl alcohol (Table 4, entry 5; substrate scale: $15.0 \mathrm{mg}, 76 \mathrm{mmol}$ ) in $500 \mu \mathrm{L}$ of $\mathrm{D}_{2} \mathrm{O}$ containing $0.25 \mathrm{wt} \%$ of maleic acid ( $298 \mathrm{~K}$ ). 


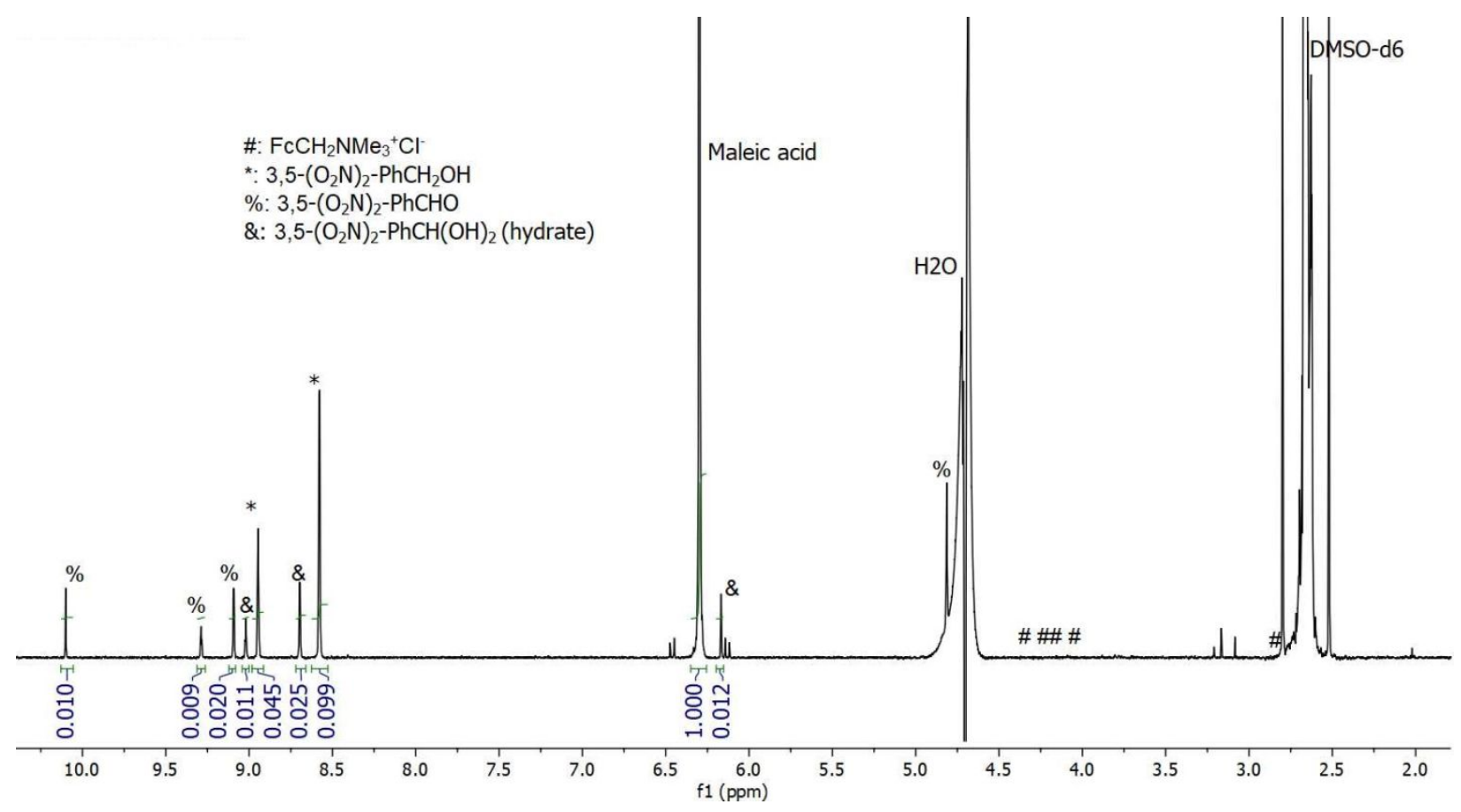

Figure S14: ${ }^{1} \mathrm{H}$ NMR spectrum of the reaction mixture of non-electrolytic, biocatalytic oxidation of 3,5dinitrobenzyl alcohol (Table 4, entry 5; substrate scale: $15.0 \mathrm{mg}$, $76 \mathrm{mmol}$ ) in $500 \mu \mathrm{L}$ of $\mathrm{D}_{2} \mathrm{O}$ containing $0.25 \mathrm{wt} \%$ of maleic acid $(298 \mathrm{~K})$.

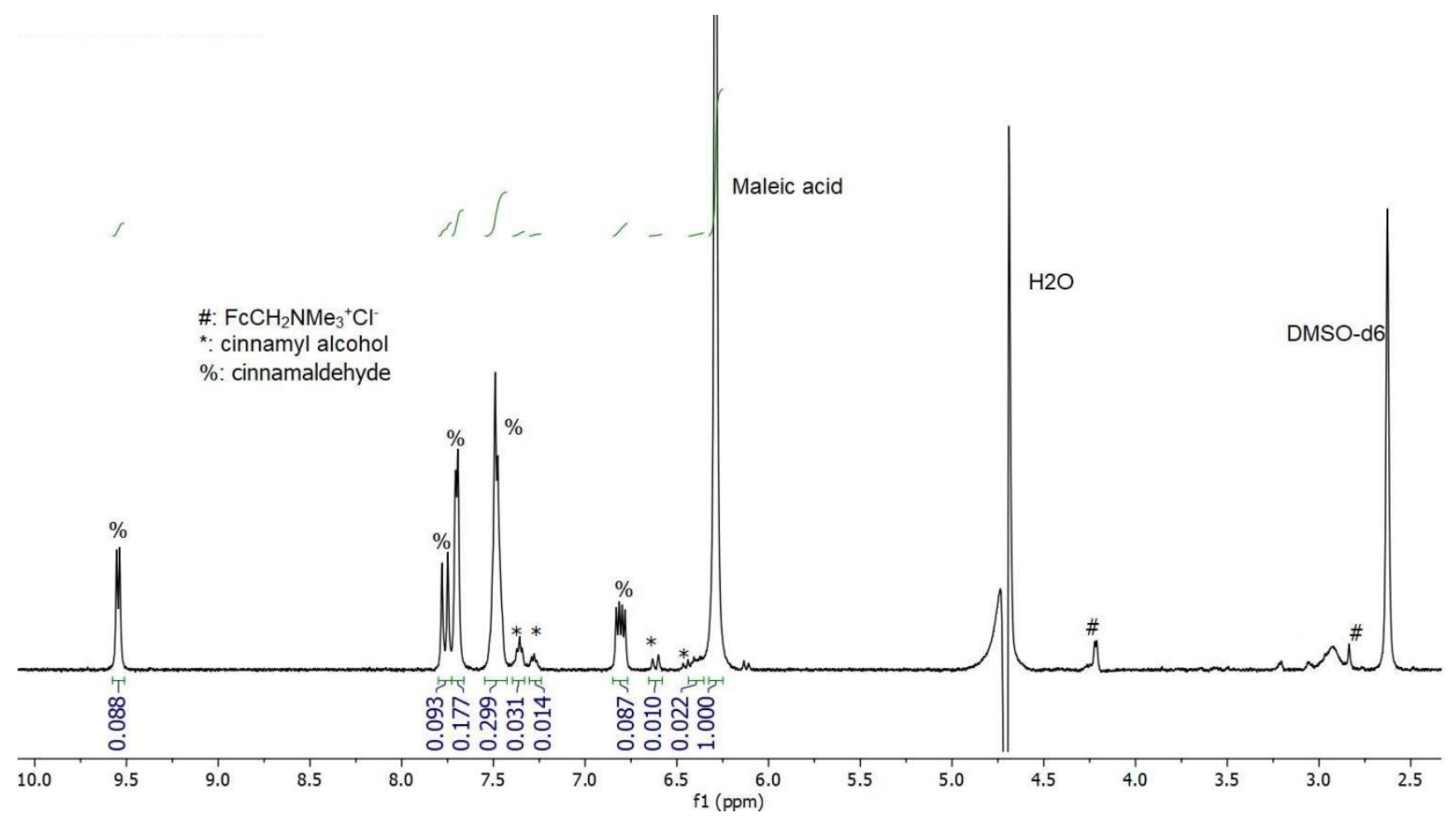

Figure S15: ${ }^{1} \mathrm{H}$ NMR spectrum of the reaction mixture of bioelectrocatalytic oxidation of cinnamyl alcohol (Table 4, entry 6; substrate scale: $15.0 \mathrm{mg}$, $112 \mathrm{mmol}$ ) in $500 \mu \mathrm{L}$ of $\mathrm{D}_{2} \mathrm{O}$ containing $0.25 \mathrm{wt} \%$ of maleic acid (298 K). 


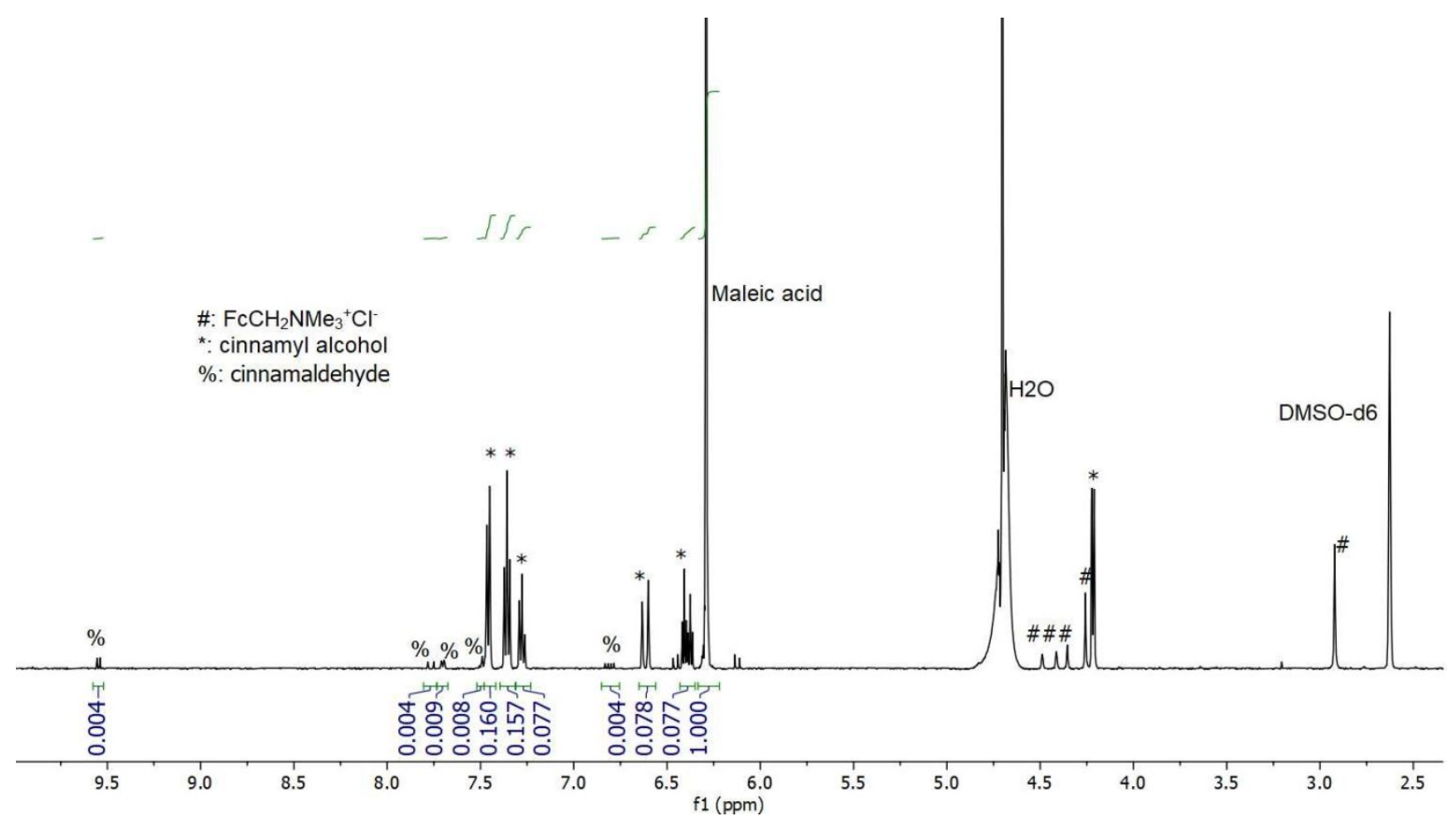

Figure S16: 'H NMR spectrum of the reaction mixture of non-electrolytic, biocatalytic oxidation of cinnamyl alcohol (Table 4, entry 6; substrate scale: $15.0 \mathrm{mg}$, $112 \mathrm{mmol}$ ) in $500 \mu \mathrm{L}$ of $\mathrm{D}_{2} \mathrm{O}$ containing $0.25 \mathrm{wt} \%$ of maleic acid $(298 \mathrm{~K})$.

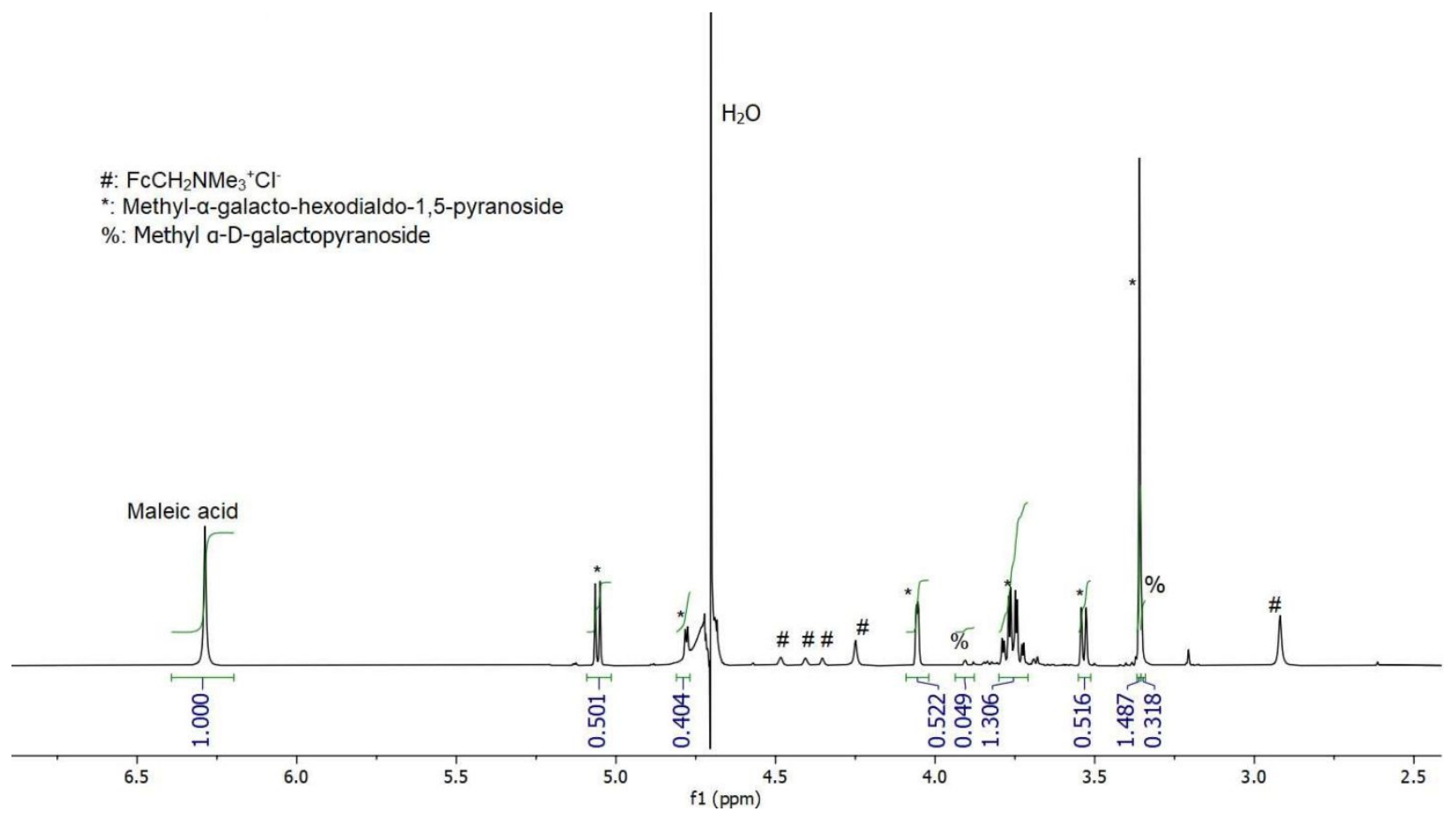

Figure S17: ${ }^{1} \mathrm{H}$ NMR spectrum of the reaction mixture of bioelectrocatalytic oxidation of methyl $\alpha$-Dgalactopyranoside (Table 5 , entry 1 ; substrate scale: $30.0 \mathrm{mg}$, $154 \mathrm{mmol}$ ) in $500 \mu \mathrm{L}$ of $\mathrm{D}_{2} \mathrm{O}$ containing $0.25 \mathrm{wt} \%$ of maleic acid $(298 \mathrm{~K})$. 


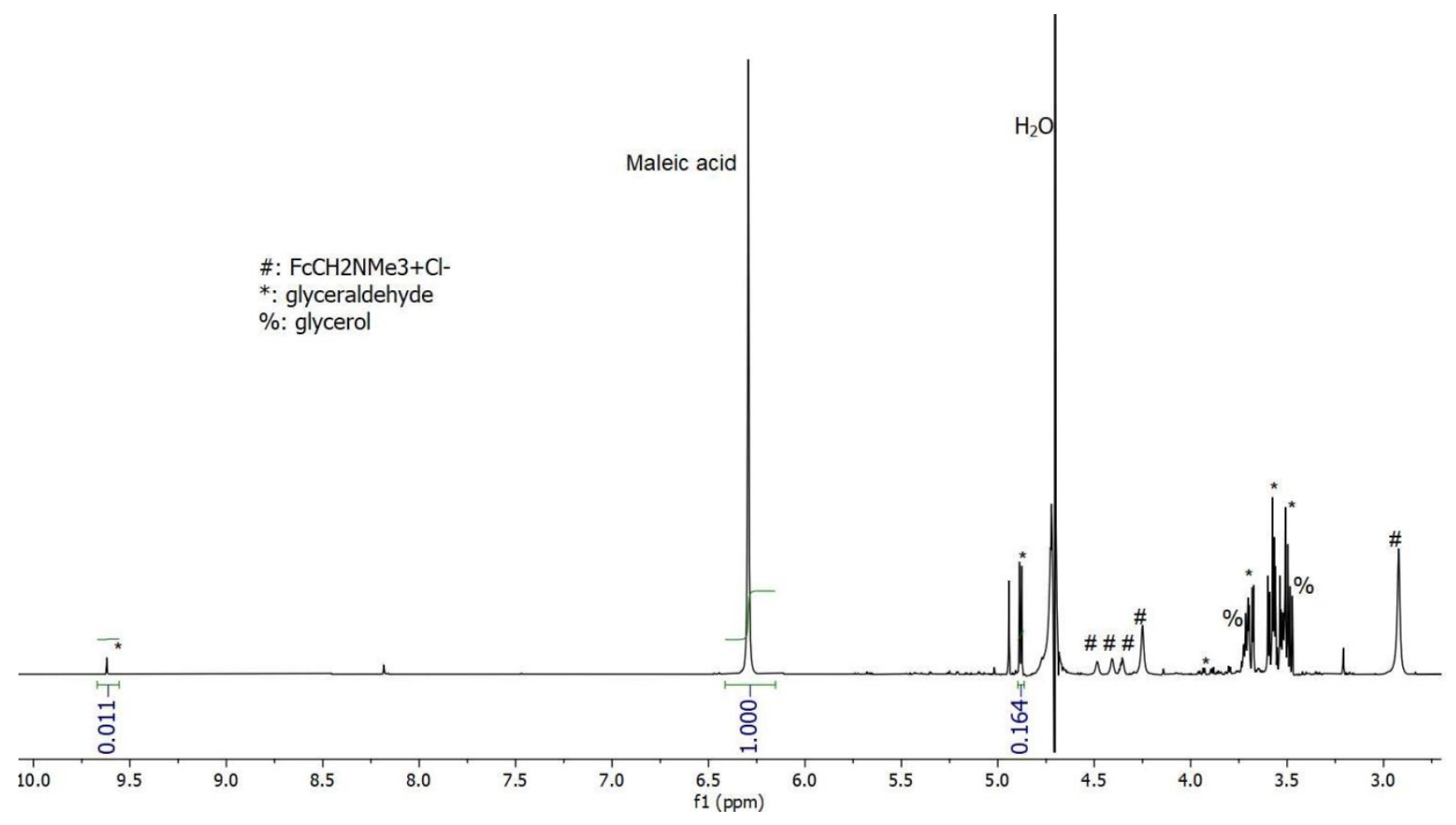

Figure S18: 'H NMR spectrum of the reaction mixture of bioelectrocatalytic oxidation of glycerol (Table 5, entry 2; substrate scale: $30.0 \mathrm{mg}, 326 \mathrm{mmol}$ ) in $500 \mu \mathrm{L}$ of $\mathrm{D}_{2} \mathrm{O}$ containing $0.2 \mathrm{wt} \%$ of maleic acid (298 K).

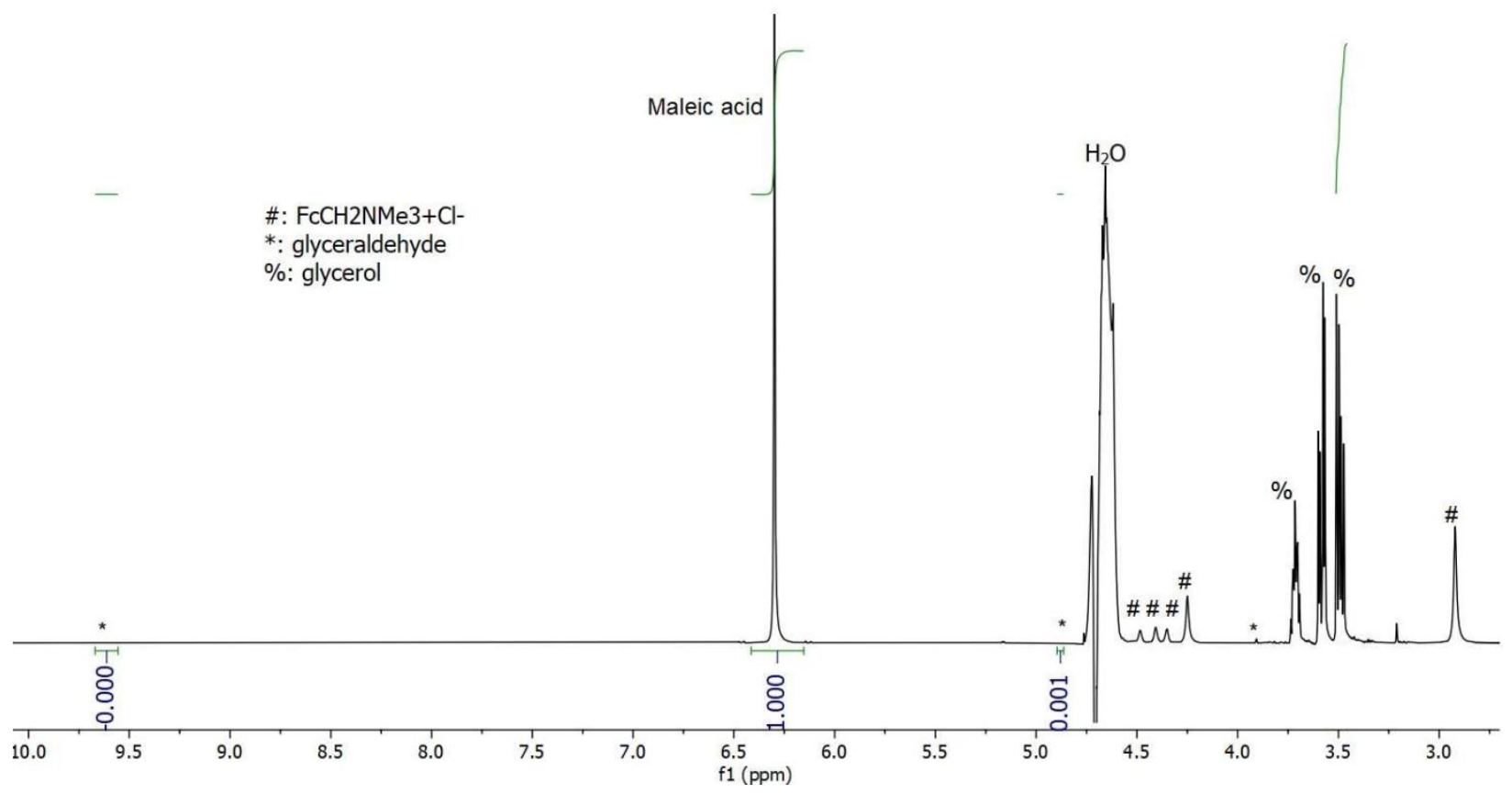

Figure S19: ${ }^{1} \mathrm{H}$ NMR spectrum of the reaction mixture of non-electrolytic, biocatalytic oxidation of glycerol (Table 5, entry 2; substrate scale: $30.0 \mathrm{mg}, 326 \mathrm{mmol}$ ) in $500 \mu \mathrm{L}$ of $\mathrm{D}_{2} \mathrm{O}$ containing $0.2 \mathrm{wt} \%$ of maleic acid (298 K). 


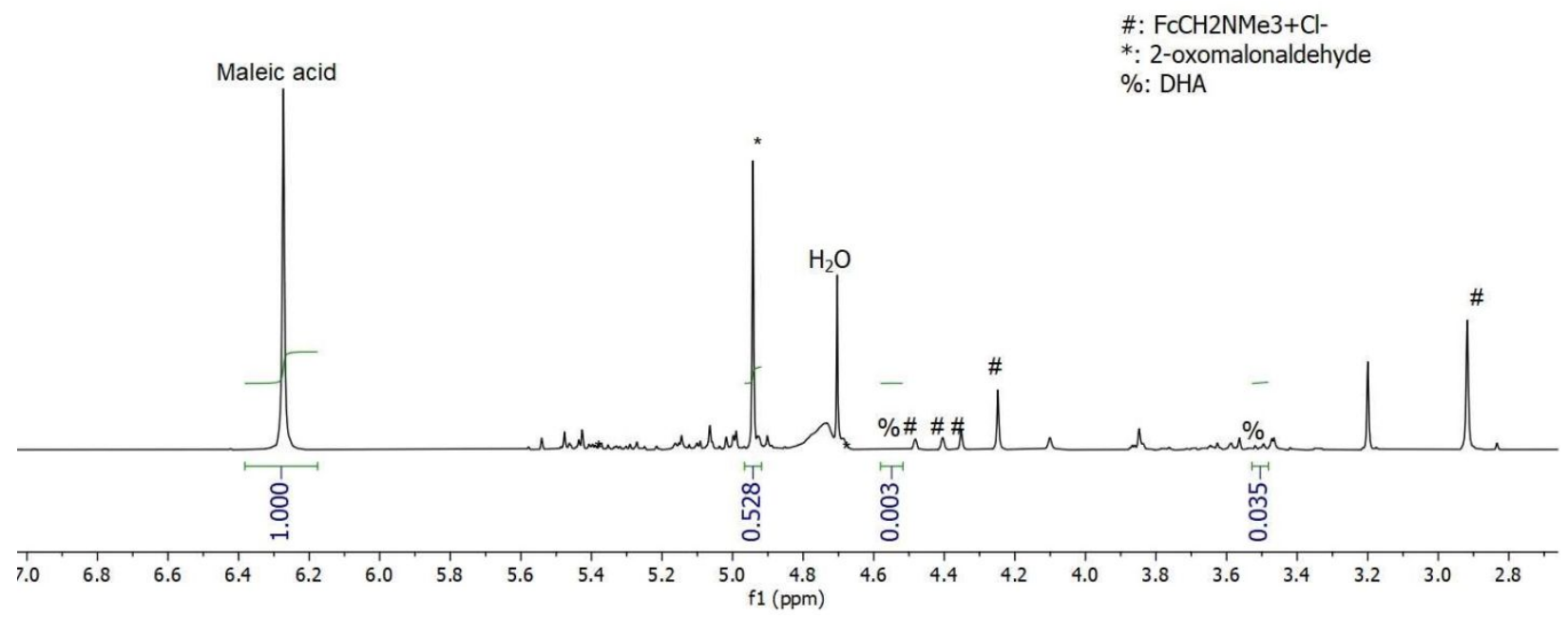

Figure S2o: ${ }^{1} \mathrm{H}$ NMR spectrum of the reaction mixture of bioelectrocatalytic oxidation of dihydroxyacetone (Table 5 , entry 3; substrate scale: $30.0 \mathrm{mg}$, $333 \mathrm{mmol}$ ) in $500 \mu \mathrm{L}$ of $\mathrm{D}_{2} \mathrm{O}$ containing $0.25 \mathrm{wt} \%$ of maleic acid (298 K).

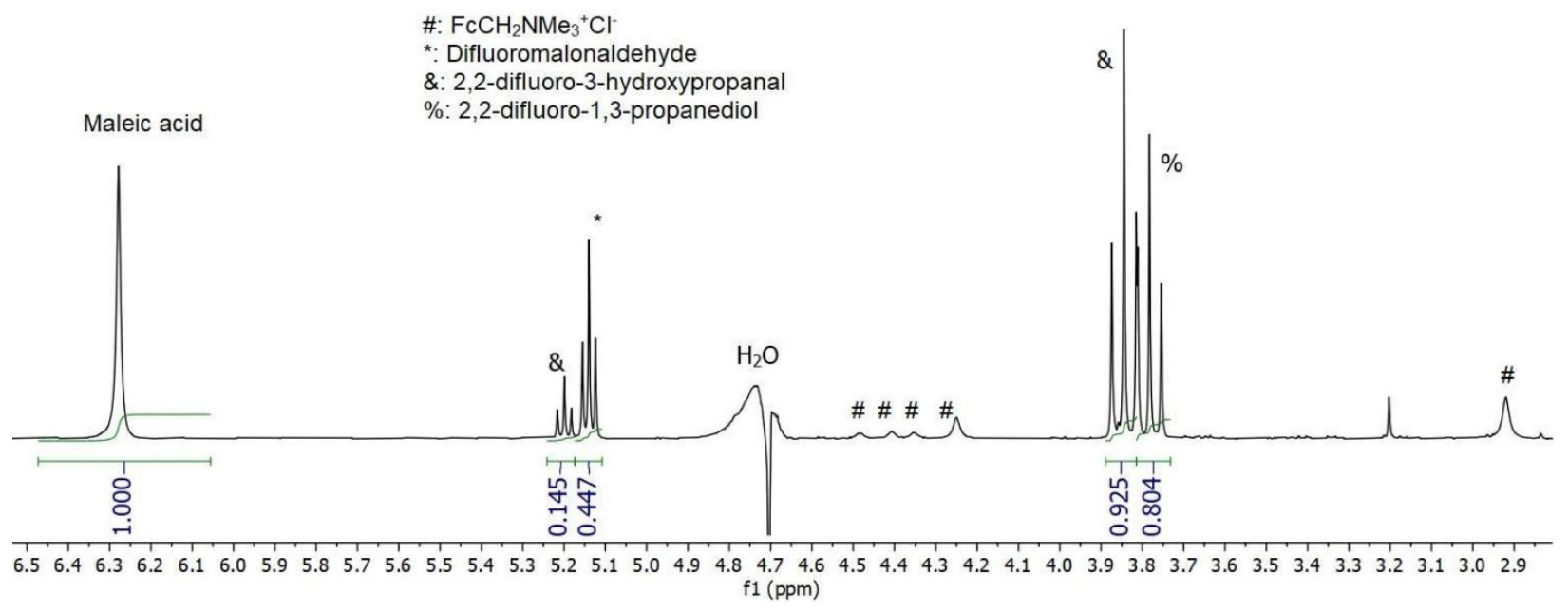

Figure S21: ' $\mathrm{H}$ NMR spectrum of the reaction mixture of bioelectrocatalytic oxidation of 2,2-difluoro-1,3propanediol (Table 5, entry 6; using GOase $\mathbf{F}_{2}$; substrate scale: $30.0 \mathrm{mg}, 268 \mathrm{mmol}$ ) in $500 \mu \mathrm{L}$ of $\mathrm{D}_{2} \mathrm{O}$ containing $0.2 \mathrm{wt} \%$ of maleic acid $(298 \mathrm{~K})$. 


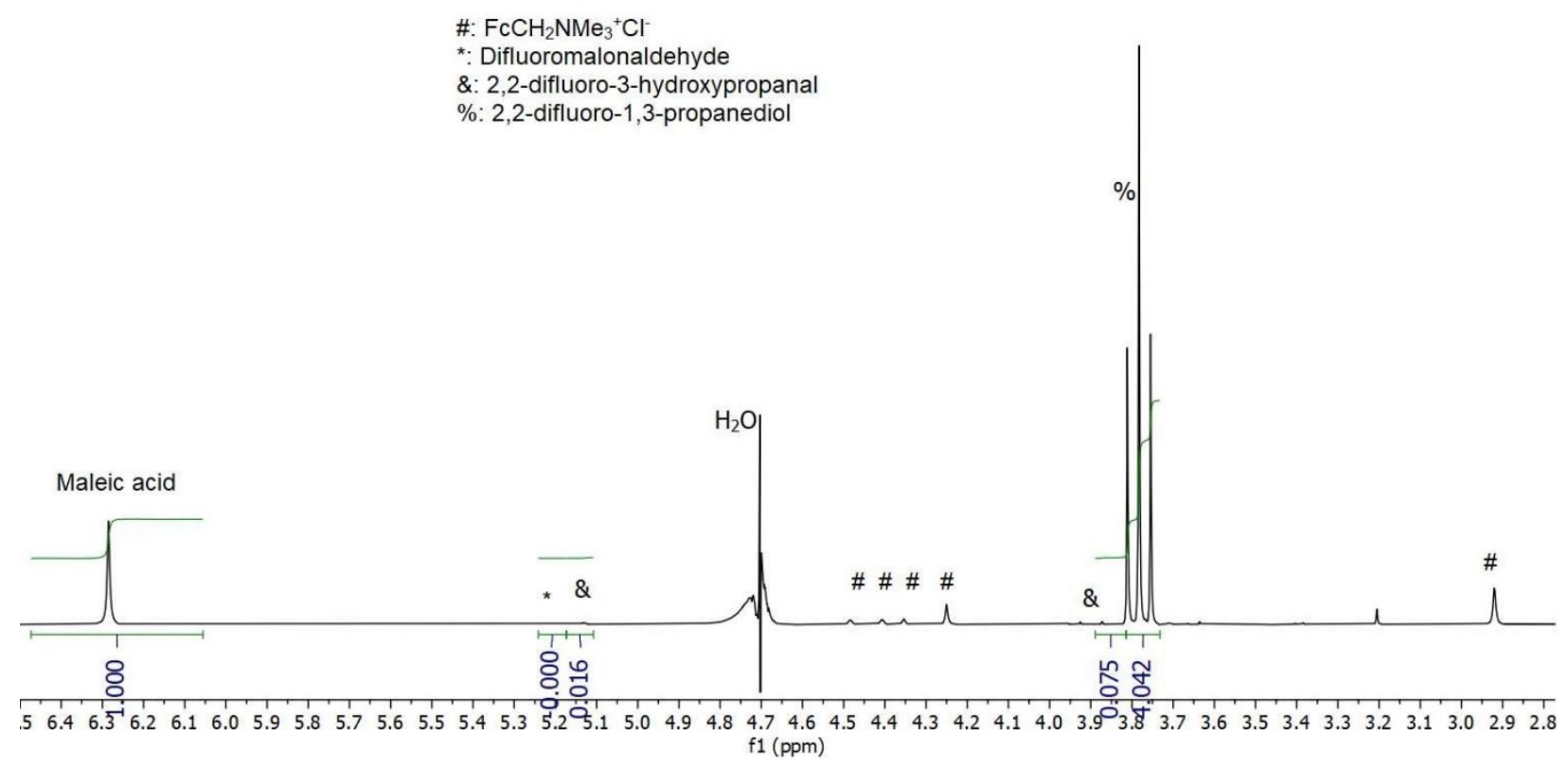

Figure S22: ${ }^{1} \mathrm{H}$ NMR spectrum of the reaction mixture of non-electrolytic, biocatalytic oxidation of 2,2-difluoro1,3-propanediol (Table 5, entry 6; using GOase $\mathbf{F}_{2}$; substrate scale: $30.0 \mathrm{mg}, 268 \mathrm{mmol}$ ) in $500 \mu \mathrm{L}$ of $\mathrm{D}_{2} \mathrm{O}$ containing $0.2 \mathrm{wt} \%$ of maleic acid $(298 \mathrm{~K})$.

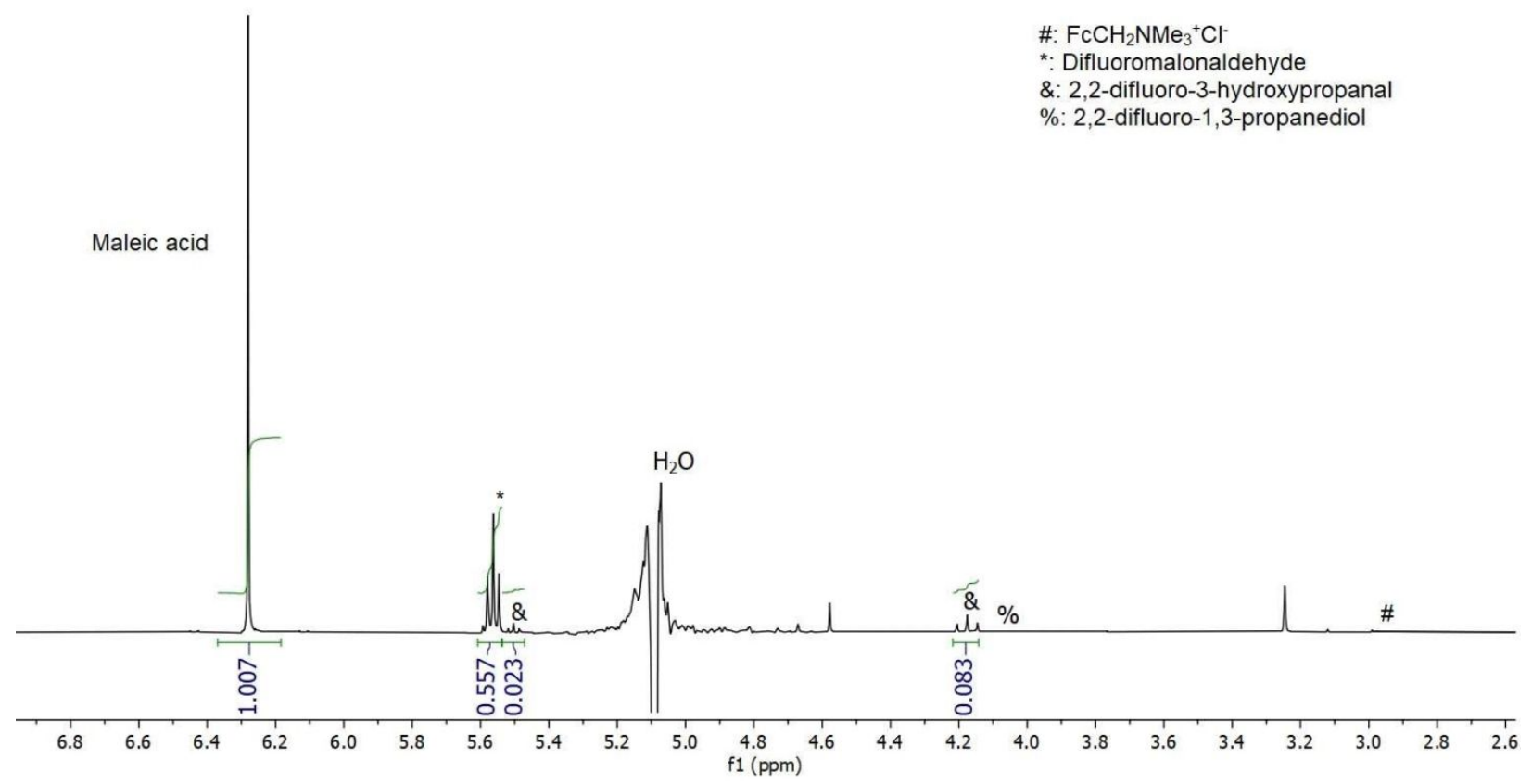

Figure S23: ' $\mathrm{H}$ NMR spectrum of the reaction mixture of bioelectrocatalytic oxidation of 2,2-difluoro-1,3propanediol (Table 5, entry 6; using GALO-105; substrate scale: $30.0 \mathrm{mg}, 268 \mathrm{mmol}$ ) in $500 \mu \mathrm{L}$ of $\mathrm{D}_{2} \mathrm{O}$ containing $0.2 \mathrm{wt} \%$ of maleic acid $(298 \mathrm{~K})$. 


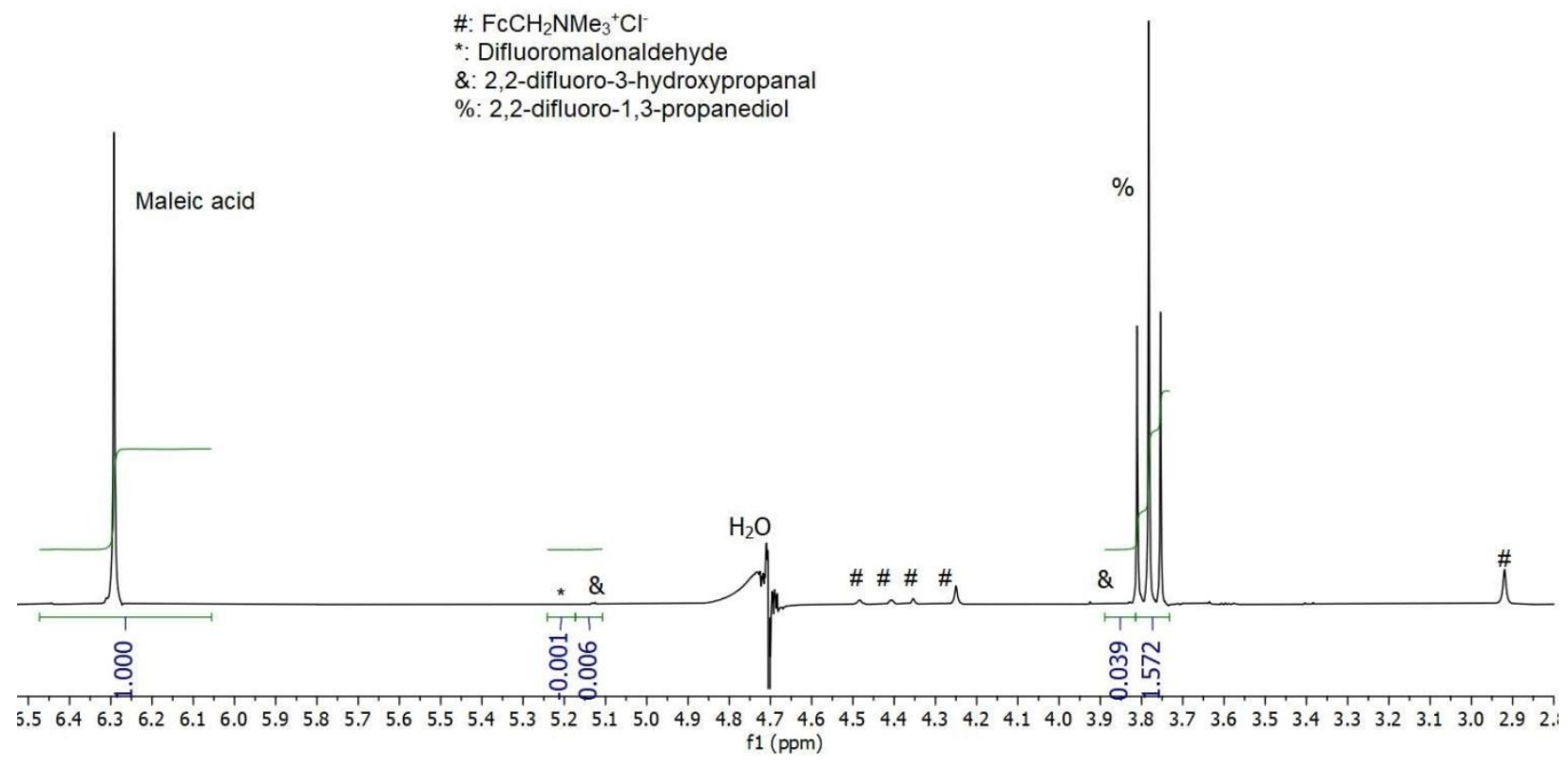

Figure S24: ' $\mathrm{H}$ NMR spectrum of the reaction mixture of non-electrolytic, biocatalytic oxidation of 2,2-difluoro1,3-propanediol (Table 5, entry 6; using GALO-105; substrate scale: $30.0 \mathrm{mg}, 268 \mathrm{mmol}$ ) in $500 \mu \mathrm{L} \mathrm{of} \mathrm{D}_{2} \mathrm{O}$ containing $0.2 \mathrm{wt} \%$ of maleic acid $(298 \mathrm{~K})$.

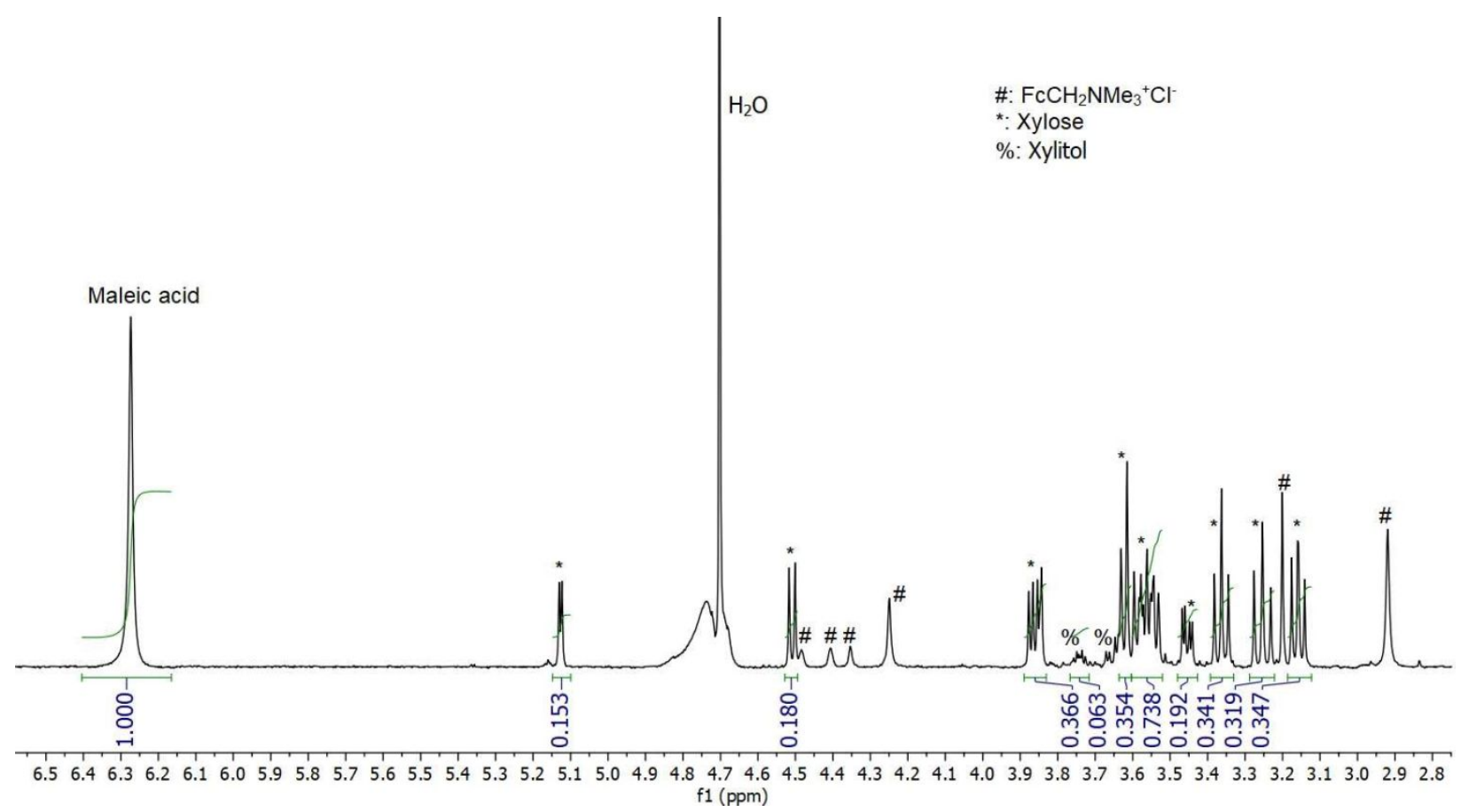

Figure S25: ${ }^{H} \mathrm{H}$ NMR spectrum of the reaction mixture of bioelectrocatalytic oxidation of xylitol (Table 5, entry 6; substrate scale: $30.0 \mathrm{mg}, 197 \mathrm{mmol})$ in $500 \mu \mathrm{L}$ of $\mathrm{D}_{2} \mathrm{O}$ containing $0.25 \mathrm{wt} \%$ of maleic acid (298 K). 


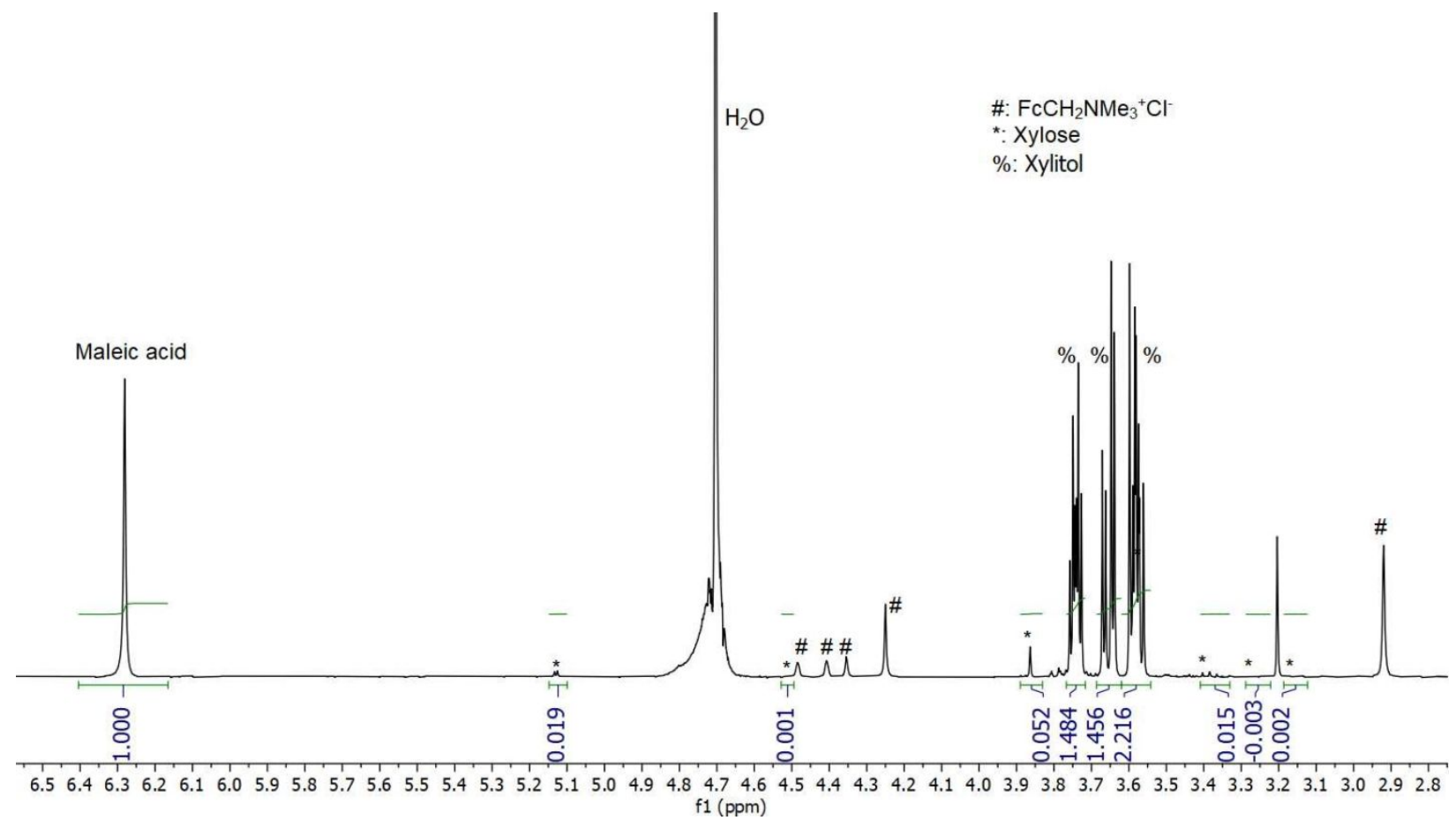

Figure S26: ${ }^{1} \mathrm{H}$ NMR spectrum of the reaction mixture of non-electrolytic, biocatalytic oxidation of xylitol (Table 5, entry 6; substrate scale: $60.0 \mathrm{mg}, 394 \mathrm{mmol}$ ) in $500 \mu \mathrm{L}$ of $\mathrm{D}_{2} \mathrm{O}$ containing $0.25 \mathrm{wt} \%$ of maleic acid (298 K).

\section{Electrochemical Studies.}

Electrochemical measurements were performed either with a PalmSens4 PALM-PS4.Fo.05 or a MultiPalmSens4 PALM-MPS4.Fo.05 from BASi (West Lafayette, Indiana) using PSTrace 5 (version 5.5.2231) or MultiTrace 4 (version 4.2.2312) software, respectively. Cyclic voltammetry (CV) experiments were conducted under ambient air or under $\mathrm{N}_{2}$ for all experiments containing the GOase enzyme. When an $\mathrm{N}_{2}$ atmosphere was required, the buffer solution was bubbled vigorously for $30 \mathrm{~min}$ and the electrochemical cells were purged for $30 \mathrm{~min}$. After addition of the enzyme, the solution was bubbled vigorously for 30 and then a flow of $\mathrm{N}_{2}$ over the solution was maintained during the measurements. The three electrode system consisted of a glassy carbon button working electrode (area $=0.071$ $\mathrm{cm}^{2}$ ) from BASi (Part \#: MF-2012), a BASi RE-5B Ag/AgCl (3M NaCl) Reference Electrode (Part \#:MF-2052), and a Pt wire counter electrode. For the experiments with $\mathrm{K}_{3} \mathrm{IrCl}_{6}$, The working electrode consisted in a platinum button working electrode $\left(\right.$ area $\left.=0.02 \mathrm{~cm}^{2}\right)$ from BASi (Part \#: MF-2013).

The GALO-104 enzyme was prepared by thawing a solution of GALO-104 at 390uM and transferring $200 \mu \mathrm{L}$ of the solution in a $2 \mathrm{~mL}$ Eppendorf tube. $1 \mu \mathrm{L}$ of 10omM Cu stock was added and the final mixture was stirred on a vortex stirrer for 3os. The solution was then allowed to age for 90 120 minutes. The CV samples were prepared as following:

a) $1.66 \mathrm{~mL}$ of $\mathrm{NaPi}$ buffer was placed in a electrochemical cell (VC-2 from BASi), and $120 \mu \mathrm{L}$ of Triol (18 wt $\%$, $1.58 \mathrm{M}$ ) and $20 \mu \mathrm{L}$ of $10 \mathrm{mM}$ mediator were added. Finally, $200 \mu \mathrm{L}$ of aged GOAse/Cu mixture was added. The final concentration of species in solution is $95 \mathrm{mM}$ Triol, $100 \mu \mathrm{M}$ mediator, $39 \mu \mathrm{M}$ GOase, $50 \mu \mathrm{M}$ Cu. The CV samples with mediator only were prepared as following: $1.86 \mathrm{~mL}$ of NaPi buffer was placed in a electrochemical cell (VC-2 from BASi), and $120 \mu \mathrm{L}$ of Triol (18 wt $\%, 1.58 \mathrm{M})$ and $20 \mu \mathrm{L}$ of $10 \mathrm{mM}$ mediator were added.

b) $0.83 \mathrm{~mL}$ of NaPi buffer was placed in a electrochemical cell (VC-2 from BASi), and 6o $\mu \mathrm{L}$ of Triol (18 wt\%, 1.58 M) and $10 \mu \mathrm{L}$ of $10 \mathrm{mM}$ mediator were added. The $\mathrm{CV}$ was recorded for the mediator alone. After that, $100 \mu \mathrm{L}$ of 
aged GOAse/Cu mixture was added. The peak current for the mediator alone was divided by 1.11 to account for the dilution by the GOase solution.

The experiments were run in triplicate for each mediator. A similar procedure was used for the $\mathrm{pH}$ dependence experiment, with the only difference being the use of either $\mathrm{pH} 7,8$ or $9 \mathrm{NaPi}$ buffer.

All potentials are reported vs $\mathrm{Ag} / \mathrm{Ag}^{+}$(in $3 \mathrm{M} \mathrm{NaCl}$ ). The scans were started at either o $\mathrm{V}$ or $0.2 \mathrm{~V}$ and the scan was run towards higher positive potential (towards oxidation) and the potential window was adjusted based on the mediator potential. The scan rate was varied between $5,10,20,50,100$ and $200 \mathrm{mV} \cdot \mathrm{s}^{-1}$. The peak or catalytic current was determined using PSTrace or MultiTrace peak finder algorithm. The rate of electron transfer between the enzyme and the mediator were calculated using the following equation.

$\frac{i_{p}}{i_{p}^{0}} \approx \frac{\sqrt{\lambda}}{0.446} \sqrt{\frac{2}{\sigma}\left[1-\frac{1}{\sigma} \ln (1+\sigma)\right]}$

With $i_{p}$ being the catalytic current, $i_{p}^{0}$ the peak current without enzyme,

$\lambda=\frac{2 k_{c} C_{E}^{0} R T}{F v}\left(\mathrm{~s}_{4}\right)$

Where $k_{c}$ is the rate between the mediator and the enzyme, $C_{E}^{0}$ is the enzyme concentration, $R$ is the gas constant, $T$ is the temperature, $F$ is Faraday's constant and $v$ is the scan rate,

$\sigma=\frac{k_{c} C_{P}^{0}}{k_{2}}\left(1+\frac{k_{-1}+k_{2}}{k_{1} C_{S}^{0}}\right)\left(\mathrm{S}_{5}\right)$

Where $C_{P}^{0}$ is the mediator concentration, $C_{S}^{0}$ is the substrate concentration, $k_{1}, k_{-1}, k_{2}$ are the rates for the following reactions

$E+S \stackrel{k_{1}}{\rightarrow} E S$

$E S \stackrel{k_{-1}}{\rightarrow} E+S$

$E S \stackrel{k_{2}}{\rightarrow} P$

When $\sigma \rightarrow 0$, the equation simplifies to

$\frac{i_{p}}{i_{p}^{0}} \approx \frac{\sqrt{\lambda}}{0.446}(\mathrm{~S} 6)$

Plotting $\frac{i_{p}}{i_{p}^{0}} \mathrm{vs} \sqrt{\frac{2 C_{E}^{0} R T}{F v}}$ gives a linear plot from which $k_{c}$ is the slope and which was extracted by linear fitting with the intersect set to 0 .

For 4-Acetamido-2,2,6,6-tetramethylpiperidine 1-oxyl, we observed loss of reversibility at low scan rates due to slow reaction with the substrate, as a result, only the scan rates displaying reversibility were used to calculate the rate for this mediator.

The redox potential of each mediator was calculated by averaging the potential of the oxidation peak and the reduction peak in the reversible CV trace:

$E_{\text {mediator }}^{0}=\frac{E_{o x}+E_{\text {red }}}{2}\left(\mathrm{~S}_{7}\right)$ 


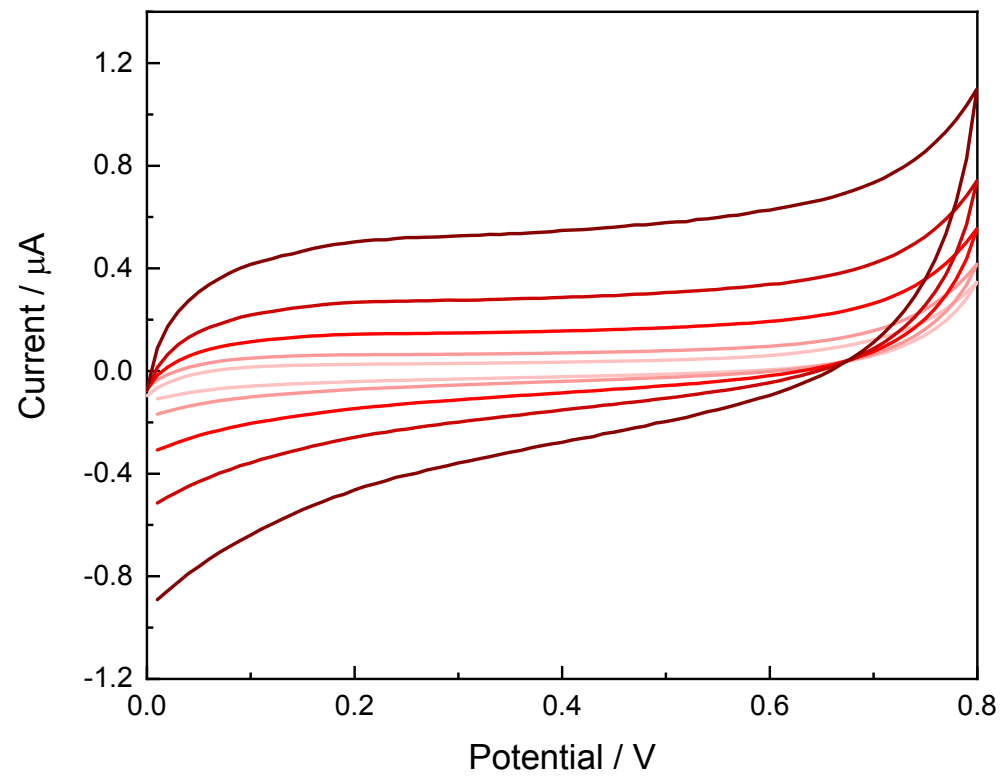

Figure S27: CV of $95 \mathrm{mM}$ Triol, $39 \mu \mathrm{M}$ GALO-104, $50 \mu \mathrm{M} \mathrm{Cu} .:(-) 10 \mathrm{mV} \cdot \mathrm{s}^{-1}$, (一) $20 \mathrm{mV} \cdot \mathrm{s}^{-1}$, (一) $50 \mathrm{mV} \cdot \mathrm{s}^{-1},($ ) 100 $\mathrm{mV} . \mathrm{s}^{-1},(-) 200 \mathrm{mV} \cdot \mathrm{s}^{-1}$.

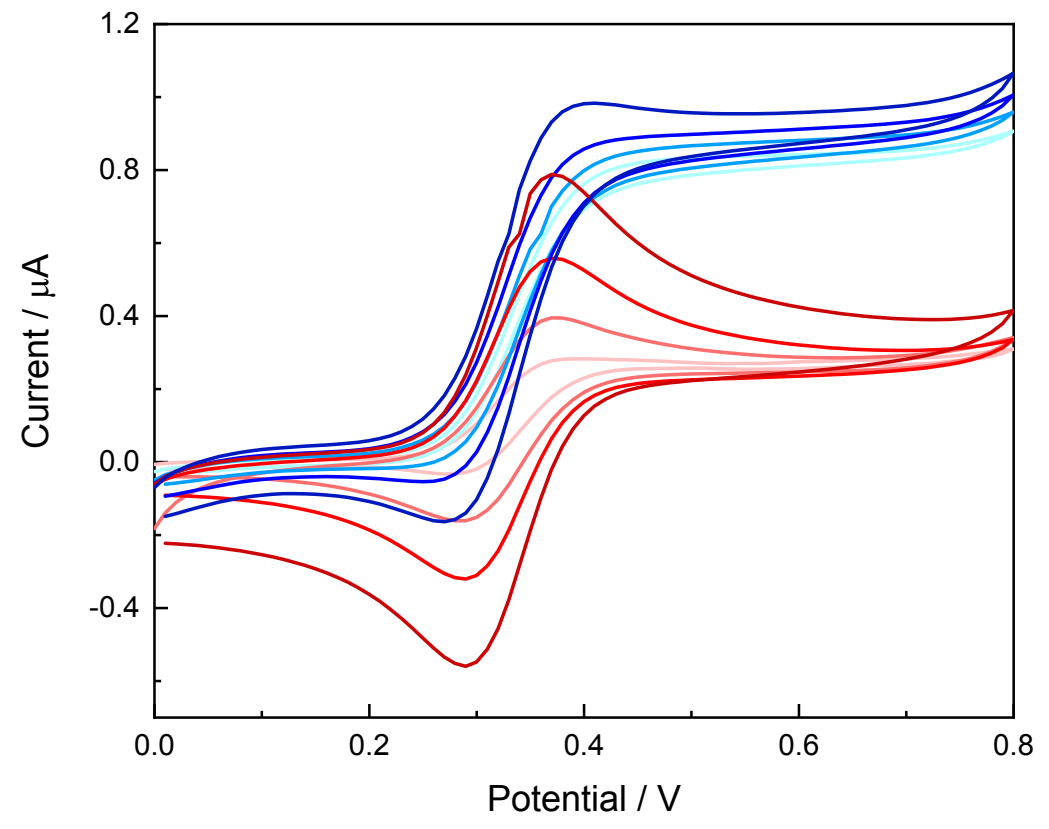


Figure S28: CV of $95 \mathrm{mM}$ Triol, $100 \mu \mathrm{M}$ Ferrocenecarboxylic acid: (-) $2 \mathrm{mV} \cdot \mathrm{s}^{-1},(-) 5 \mathrm{mV} \cdot \mathrm{s}^{-1},\left(\right.$, $10 \mathrm{mV} \cdot \mathrm{s}^{-1},($ ) $20 \mathrm{mV} . \mathrm{s}^{-1}$. CV of $95 \mathrm{mM}$ Triol, $100 \mu \mathrm{M}$ Ferrocenecarboxylic acid, $39 \mu \mathrm{M}$ GALO-104, $50 \mu \mathrm{M}$ Cu. Scan rate: $(-) 2$ $\mathrm{mV} \cdot \mathrm{s}^{-1},($ ( $) 5 \mathrm{mV} \cdot \mathrm{s}^{-1},\left(\right.$ ( ) $10 \mathrm{mV} \cdot \mathrm{s}^{-1},($ ( $) 20 \mathrm{mV} \cdot \mathrm{s}^{-1}$.

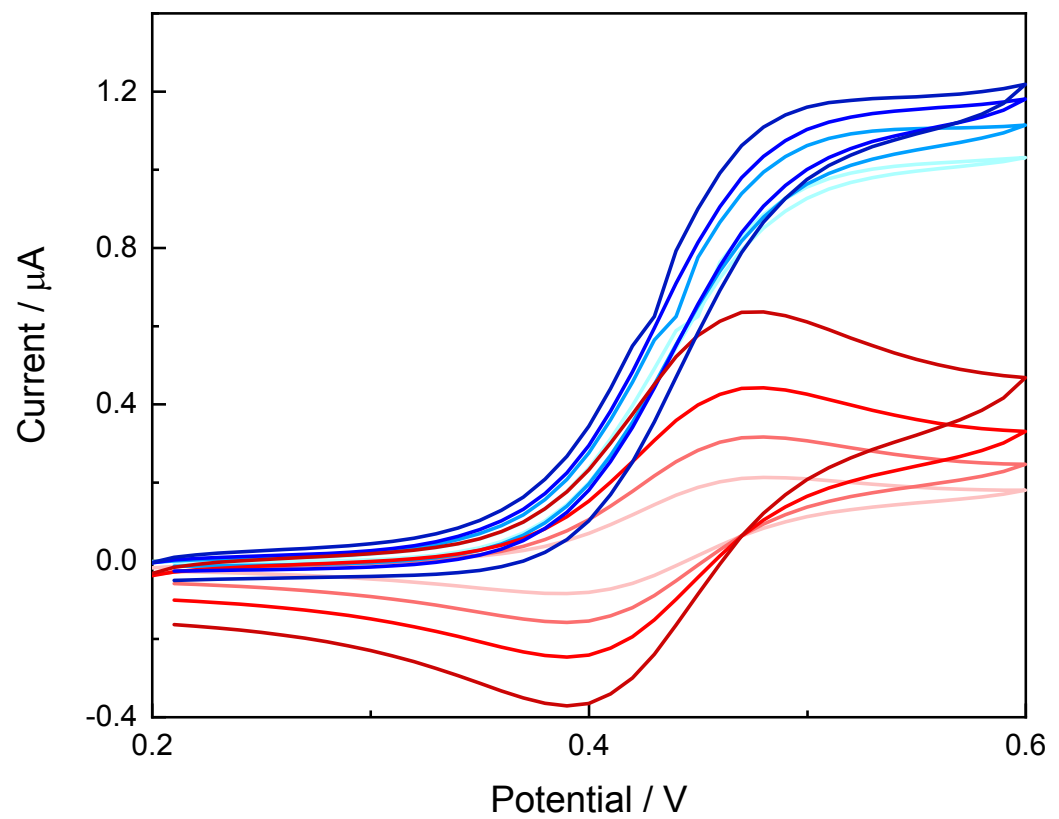

Figure S29: CV of $95 \mathrm{mM}$ Triol, $100 \mu \mathrm{M}$ N,N,N-Trimethyl-1-ferrocenylmethanaminium chloride: $(-) 2 \mathrm{mV} . \mathrm{s}^{-1}$, (一) $5 \mathrm{mV} \cdot \mathrm{s}^{-1},\left(\right.$ (一) $10 \mathrm{mV} \cdot \mathrm{s}^{-1},\left(\right.$ (一) $20 \mathrm{mV} \cdot \mathrm{s}^{-1} . \mathrm{CV}$ of $95 \mathrm{mM}$ Triol, $100 \mu \mathrm{M} \mathrm{N}, \mathrm{N}, \mathrm{N}-$ Trimethyl-1-

ferrocenylmethanaminium chloride, $39 \mu \mathrm{M}$ GALO-104, $50 \mu \mathrm{M} \mathrm{Cu}$. Scan rate: $(-) 2 \mathrm{mV} \cdot \mathrm{s}^{-1},(-) 5 \mathrm{mV} . \mathrm{s}^{-1},(-) 10$ $\mathrm{mV} \cdot \mathrm{s}^{-1},\left(\right.$ ( ) $20 \mathrm{mV} \cdot \mathrm{s}^{-1}$. 


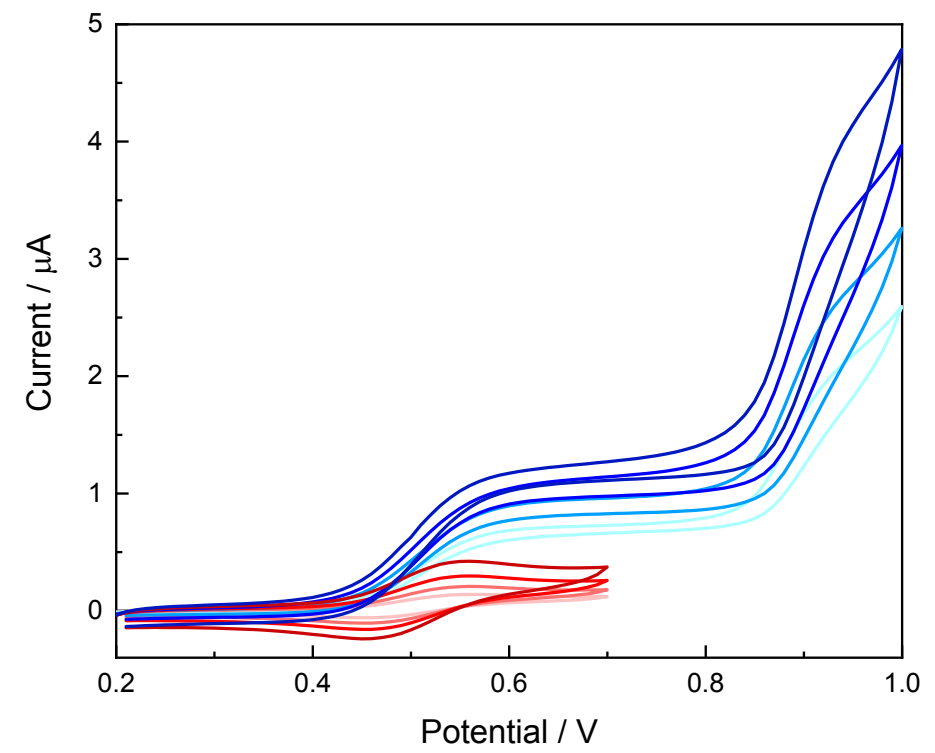

Figure S30: CV of $95 \mathrm{mM}$ Triol, $100 \mu \mathrm{M}$ 2,2'-azino-bis(3-ethylbenzothiazoline-6-sulfonic acid (ABTS): ( - ) 2 mV.s 1, (-) $5 \mathrm{mV} . \mathrm{s}^{-1},(-) 10 \mathrm{mV} \cdot \mathrm{s}^{-1},(-) 20 \mathrm{mV} . \mathrm{s}^{-1}$. CV of $95 \mathrm{mM}$ Triol, $100 \mu \mathrm{M}$ ABTS, $39 \mu \mathrm{M}$ GALO-104, $50 \mu \mathrm{M} \mathrm{Cu}$. Scan rate: (一) $2 \mathrm{mV} \cdot \mathrm{s}^{-1},\left(\right.$ ) $5 \mathrm{mV} \cdot \mathrm{s}^{-1}$, (一) $10 \mathrm{mV} \cdot \mathrm{s}^{-1}$, (一) $20 \mathrm{mV} \cdot \mathrm{s}^{-1}$. The catalytic current was measured in the $0.6-0.8 \mathrm{~V}$ region.

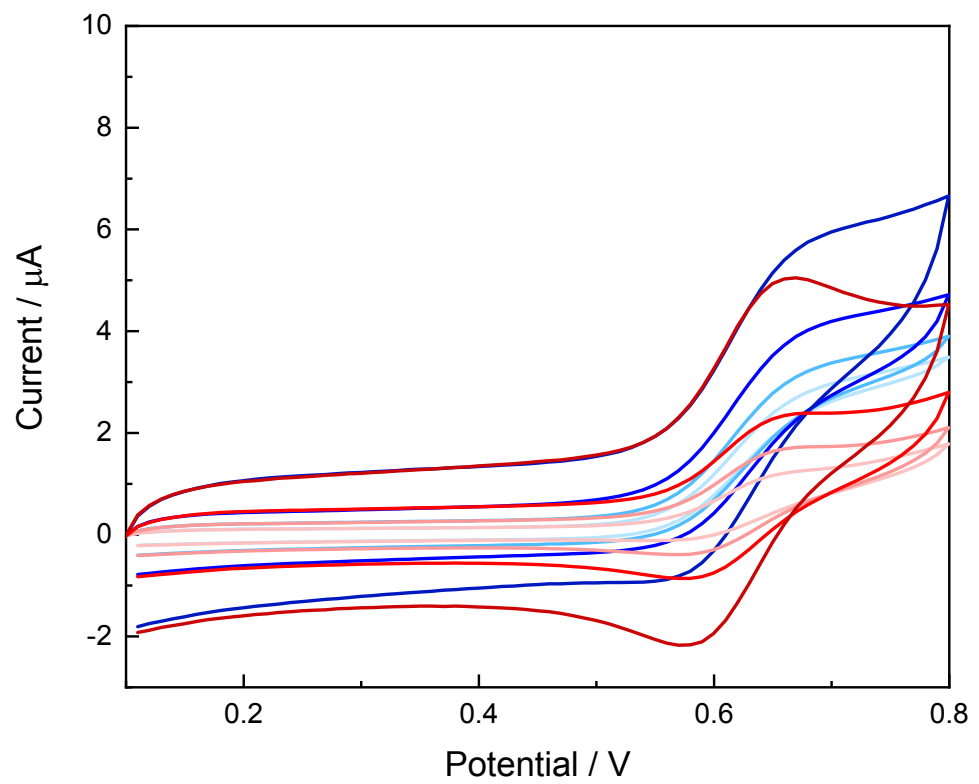

Figure S31: CV of $95 \mathrm{mM}$ Triol, $100 \mu \mathrm{M}$ 4-Acetamido-2,2,6,6-tetramethylpiperidine 1-oxyl: ( $(-) 20 \mathrm{mV} . \mathrm{s}^{-1},(-) 50$ $\mathrm{mV} \cdot \mathrm{s}^{-1},(-) 100 \mathrm{mV} \cdot \mathrm{s}^{-1},(-) 200 \mathrm{mV} \cdot \mathrm{s}^{-1}$. CV of $95 \mathrm{mM}$ Triol, $10 \mu \mathrm{M}$ 4-Acetamido-2,2,6,6-tetramethylpiperidine 1oxyl, 39 MM GALO-104, $50 \mu \mathrm{M}$ Cu. Scan rate: $(-) 20 \mathrm{mV} . \mathrm{s}^{-1},(-) 50 \mathrm{mV} . \mathrm{s}^{-1},(-) 100 \mathrm{mV} \cdot \mathrm{s}^{-1},(-) 200 \mathrm{mV} . \mathrm{s}^{-1}$ 


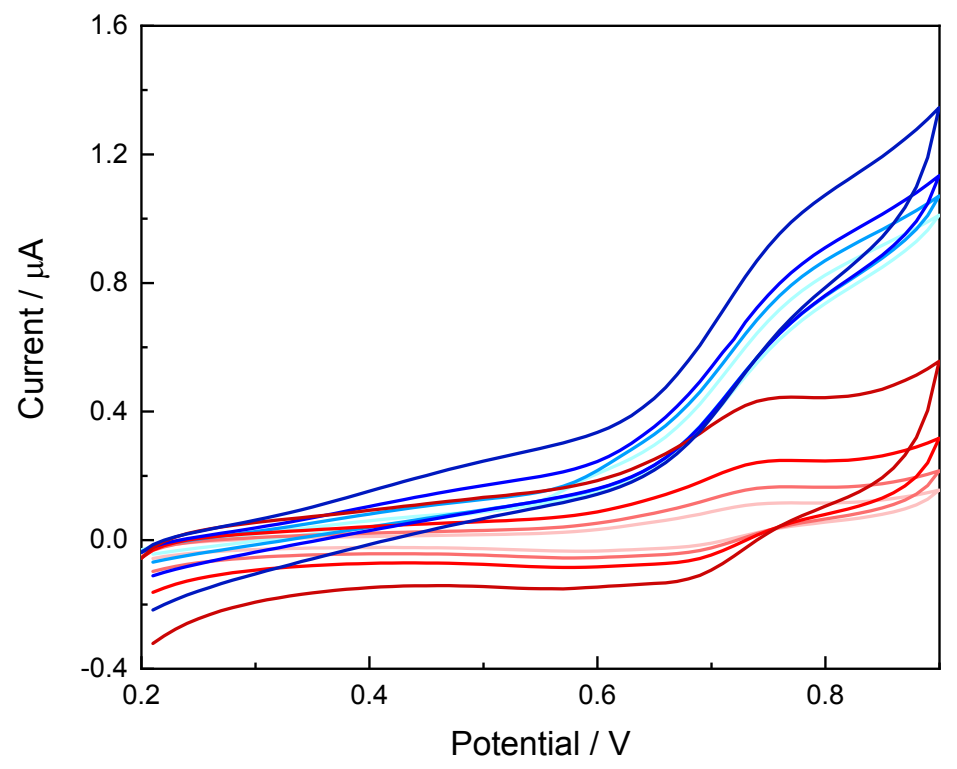

Figure S32: CV of $95 \mathrm{mM}$ Triol, $100 \mu \mathrm{M} \mathrm{K}_{3} \mathrm{IrCl}_{6}:(-) 5 \mathrm{mV} \cdot \mathrm{s}^{-1},(-) 10 \mathrm{mV} \cdot \mathrm{s}^{-1},(-) 20 \mathrm{mV} \cdot \mathrm{s}^{-1},\left(\right.$ ) $50 \mathrm{mV} \cdot \mathrm{s}^{-1} . \mathrm{CV}$ of 95 $\mathrm{mM}$ Triol, $100 \mu \mathrm{M} \mathrm{K}_{3} \mathrm{IrCl}_{6}, 39 \mu \mathrm{M}$ GALO-104, $50 \mu \mathrm{M} \mathrm{Cu}$. Scan rate: (-) $5 \mathrm{mV} \cdot \mathrm{s}^{-1},(-) 10 \mathrm{mV} \cdot \mathrm{s}^{-1},(-) 20 \mathrm{mV} \cdot \mathrm{s}^{-1},(-)$ $50 \mathrm{mV} . \mathrm{s}^{-1}$. 


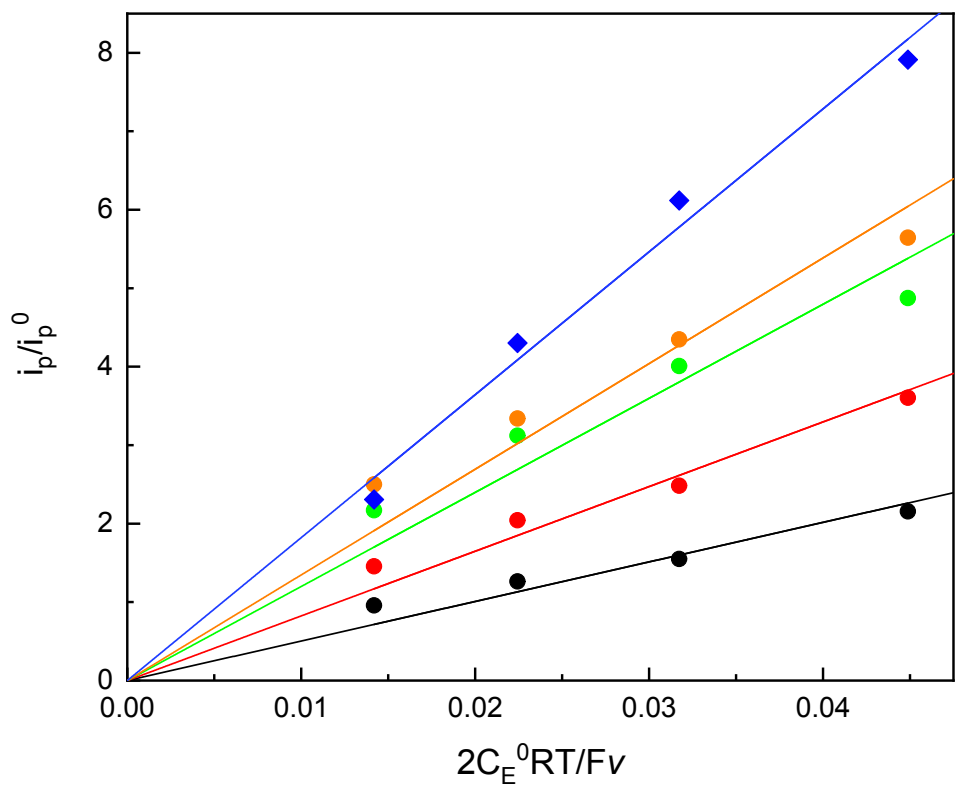

Figure S33: Plot of $\frac{i_{p}}{i_{p}^{0}} \operatorname{vs} \frac{2 C_{E}^{0} R T}{F v}$ for one run of Ferrocenecarboxylic acid $(\bullet)$ and linear fit $(-)$; N,N,N-Trimethyl-1ferrocenylmethanaminium chloride $\left(^{\circ}\right)$ and linear fit $(-)$; ABTS $\left(^{\circ}\right)$ and linear fit $(-)$; 4-Acetamido-2,2,6,6tetramethylpiperidine 1-oxyl $\left(^{\circ}\right)$ and linear fit $(-) ; \mathrm{K}_{3} \operatorname{IrCl}_{6}(\bullet)$ and linear fit $(-)$.

\begin{tabular}{|l|l|l|l|}
\hline Mediator & Eo $(\mathbf{V}, \mathbf{v s ~ A g / A g C l )}$ & $\mathbf{k}(\mathbf{k})$ \\
\hline Ferrocenecarboxylic acid & 0.33 & $3.2 \times 10^{3} \pm 1.0$ & $8.1 \pm 0.31$ \\
\hline $\begin{array}{l}\text { N,N,N-Trimethyl-1- } \\
\text { ferrocenylmethanaminium chloride }\end{array}$ & 0.43 & $5.1 \times 10^{3} \pm 1.3$ & $8.5 \pm 0.25$ \\
\hline ABTS & 0.505 & $9.5 \times 10^{3} \pm 4.5$ & $9.1 \pm 0.60$ \\
\hline $\begin{array}{l}\text { 4-Acetamido-2,2,6,6- } \\
\text { tetramethylpiperidine 1-oxyl }\end{array}$ & 0.65 & $3.3 \times 10^{4} \pm 1.7$ & $10.3 \pm 0.47$ \\
\hline $\mathrm{K}_{3} \mathrm{IrCl}_{6}$ & 0.725 & $3.3 \times 10^{4}$ & 10.4 \\
\hline
\end{tabular}

Table S5: Redox potential and rate constants for the different mediators

\begin{tabular}{|l|l|l|l|l|}
\hline Mediator & $\begin{array}{l}\mathbf{E}(\mathbf{V}, \mathbf{v s} \\
\mathbf{A g} / \mathbf{A g C l})\end{array}$ & $\mathbf{k}$ & $\mathbf{p H}$ & $\mathbf{l n}(\mathbf{k})$ \\
\hline Ferrocenecarboxylic acid & 0.33 & $3.1 \times 10^{3}$ & 7 & 8.1 \\
\hline Ferrocenecarboxylic acid & 0.33 & $5.3 \times 10^{3}$ & 8 & 8.58 \\
\hline Ferrocenecarboxylic acid & 0.33 & $8.6 \times 10^{3}$ & 9 & 9.06 \\
\hline
\end{tabular}

Table S6: rate constants for ferrocenecarboxylic acid at various $\mathrm{pH}$ 


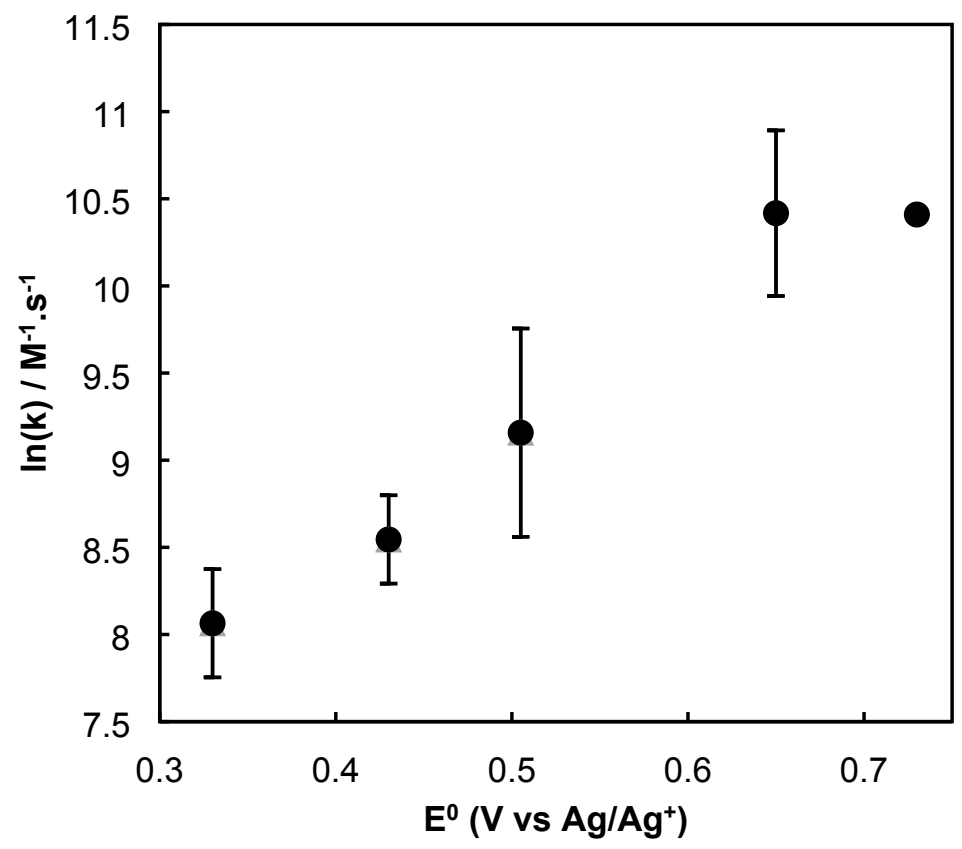

Figure S34: Plot of $\log (\mathrm{k})$ against $\mathrm{E}_{\text {mediator }}^{\mathrm{o}}(\bullet)$.

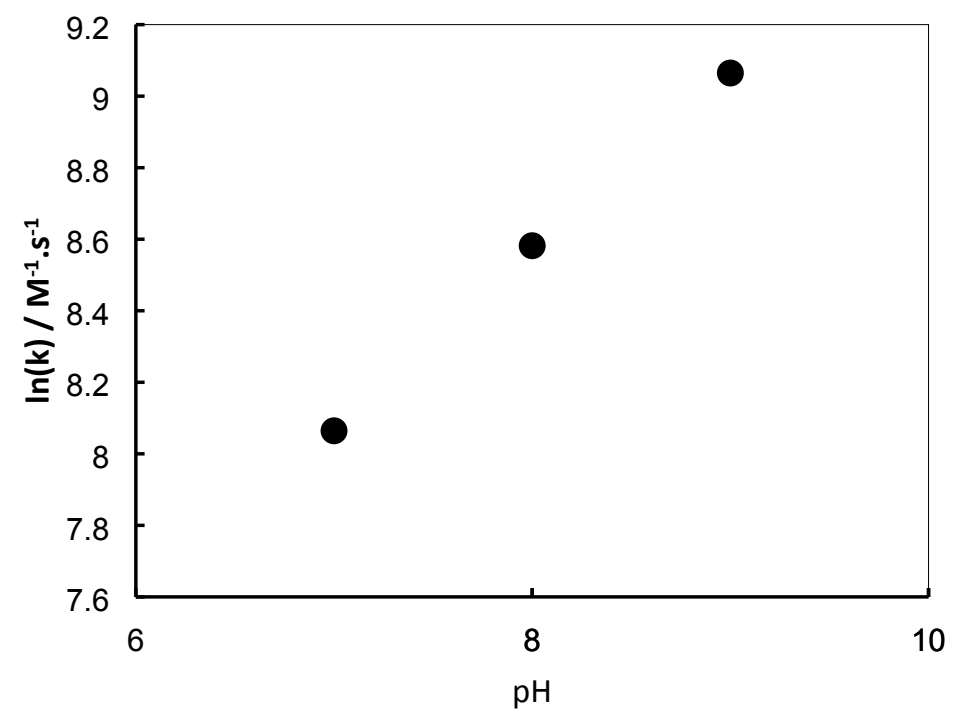

Figure S35: $_{\text {Plot }}$ of $\log (\mathrm{k})$ against $\mathrm{pH}(\bullet)$. 


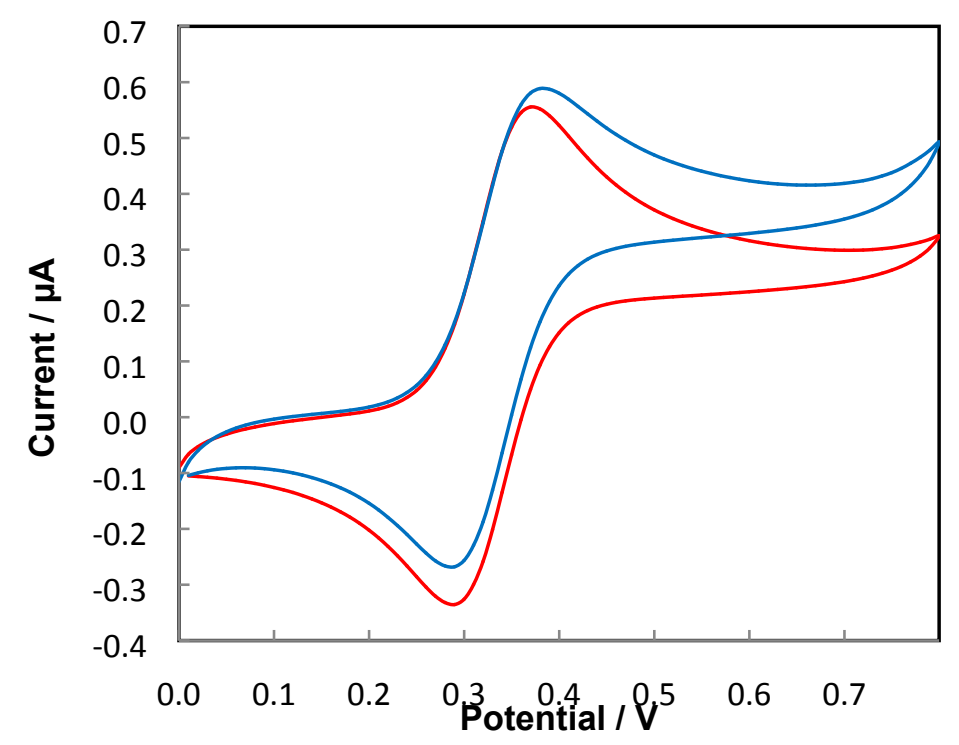

Figure S36: CV of $100 \mu \mathrm{M}$ Ferrocenecarboxylic acid: (-) $10 \mathrm{mV} \cdot \mathrm{s}^{-1} \mathrm{CV}$ of $100 \mu \mathrm{M}$ Ferrocenecarboxylic acid, $39 \mu \mathrm{M}$ GALO-104, $50 \mu \mathrm{M} \mathrm{Cu}$. Scan rate: (一) $10 \mathrm{mV} \cdot \mathrm{s}^{-1}$

\section{UV-Vis studies.}

The UV-Vis system used to record spectra consists in an OceanInsight DH-20oo-BAL light source directly connected to an OceanInsight SQUARE ONE cuvette holder using threaded joints. The cuvette holder was directly connected to an OceanInsight FLAME-S-UV-VIS spectrometer. The spectra were recorded using OceanView 2. The exposure time was automatically adjusted to be under the saturation limit of the spectrometer. 10 scans were averaged to produce a spectrum. A background of the light source and a dark were taken before each experiment. A full spectrum was recorded every $10 \mathrm{~s}$ or every $30 \mathrm{os}$. The spectra were compiled in Matlab and were imported in Mettler Toledo IC IR. The kinetic traces were generated by plotting the area below each peak using a 2 point baseline defined by the start and end of the peak area.

The GALO-104 solution was prepared by transferring $100 \mu \mathrm{L}$ of a solution of GOAse buffer exchanged with $\mathrm{NaPi}$, $\mathrm{pH} 7$ (concentration: $404 \mu \mathrm{M}$ ) in a fused quartz Thorlabs sub-micro cuvette with a light path of $10 \mathrm{~mm}$ (Part \#: CV1oQ1ooS) containing $100 \mu \mathrm{L}$ of $\mathrm{NaPi}$ buffer and the resulting solution was mixed using a pipette. $2 \mu \mathrm{L}$ of $50 \mathrm{mM}$ $\mathrm{Cu}$ stock was added and the final mixture was mixed by repeated pipetting. The final concentration of species in solution is $202 \mu \mathrm{M}$ GOase, $0.5 \mathrm{mM} \mathrm{Cu}$. After the spectrum showed conversion into to the $\mathrm{Cu}(\mathrm{II})$ inactive GOase species, $4 \mu \mathrm{L}$ of o.1M sodium persulfate solution in $\mathrm{NaPi}$, $\mathrm{pH} 7$ buffer. The solution was mixed by repeated pipetting. 


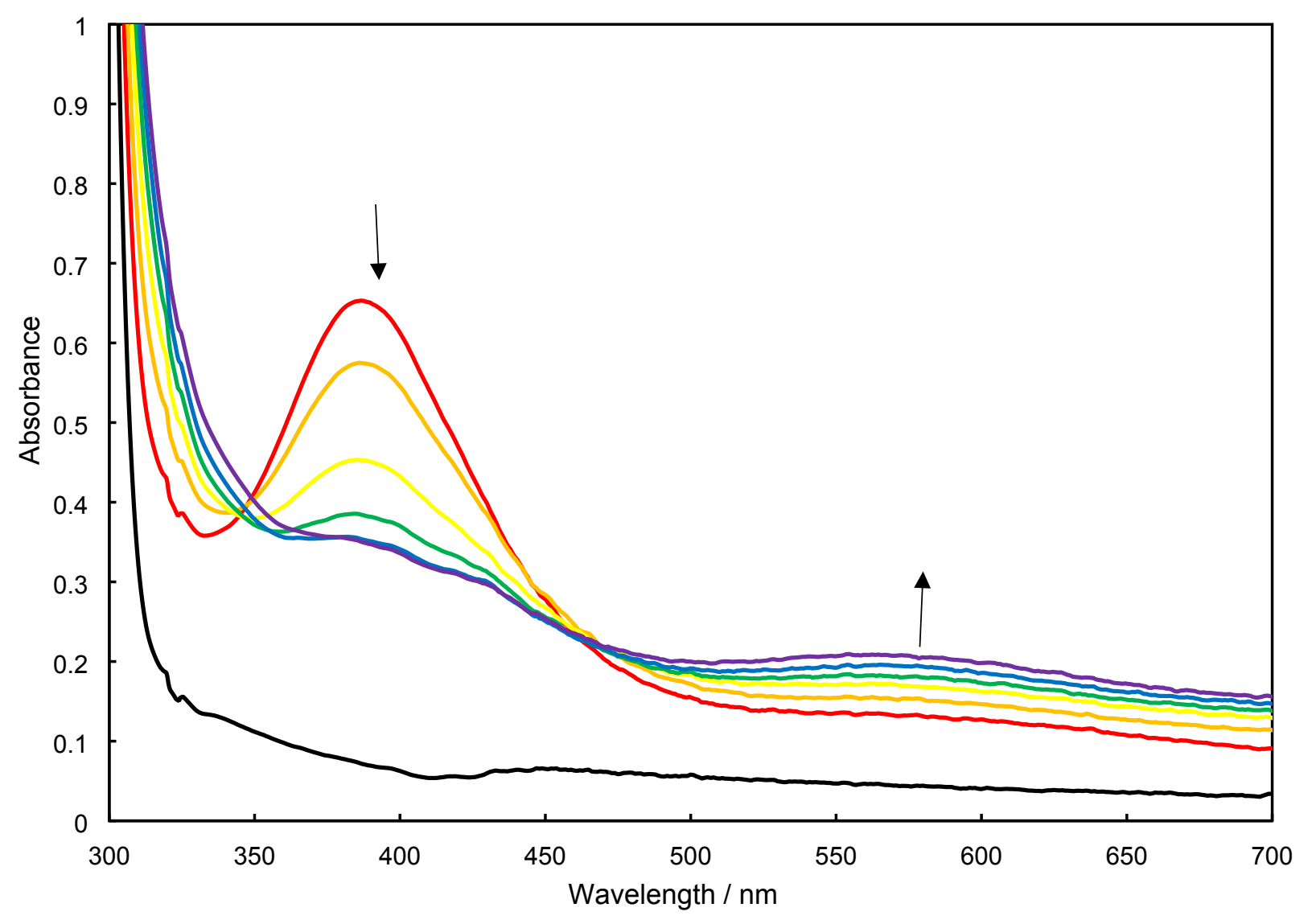

Figure S37: UV-Vis spectra of apo-GALO-104 (-). 5 min After addition of $\mathrm{Cu}(-)$, 1 h after addition of $\mathrm{Cu}(-)$. The rainbow spectra in between are taken at 10 min intervals in between. The arrows indicate the direction of the changes. 


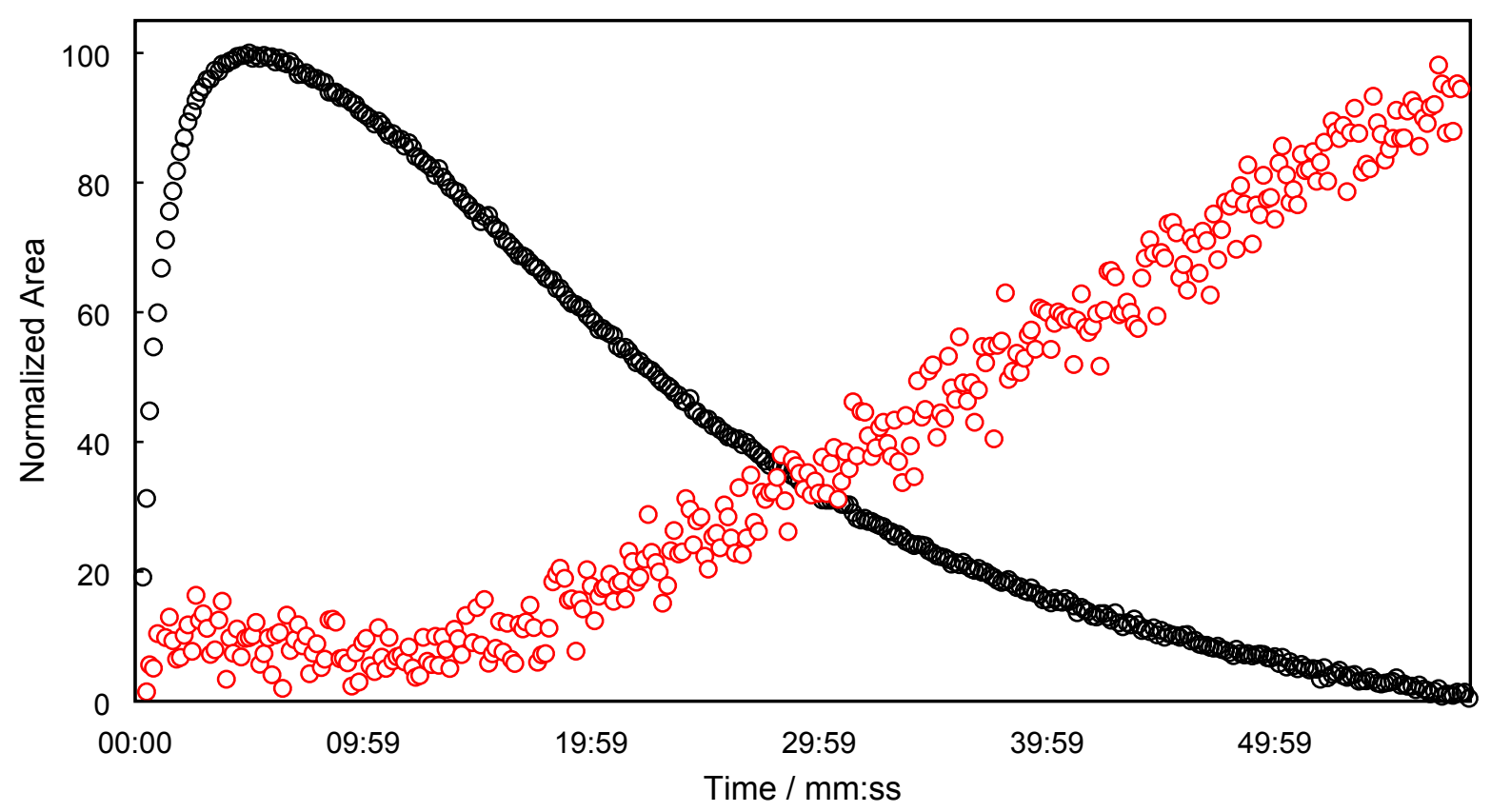

Figure S38: Single wavelength kinetic trace at $387 \mathrm{~nm}(\circ)$ and $573 \mathrm{~nm}(\circ)$. The area and the 2 point baseline was taken between $340 \mathrm{~nm}$ and $470 \mathrm{~nm}$ for the $387 \mathrm{~nm}$ peak. The area and the 2 point baseline was taken between 500 $\mathrm{nm}$ and $675 \mathrm{~nm}$ for the $573 \mathrm{~nm}$ peak. The normalized areas were plotted for clarity

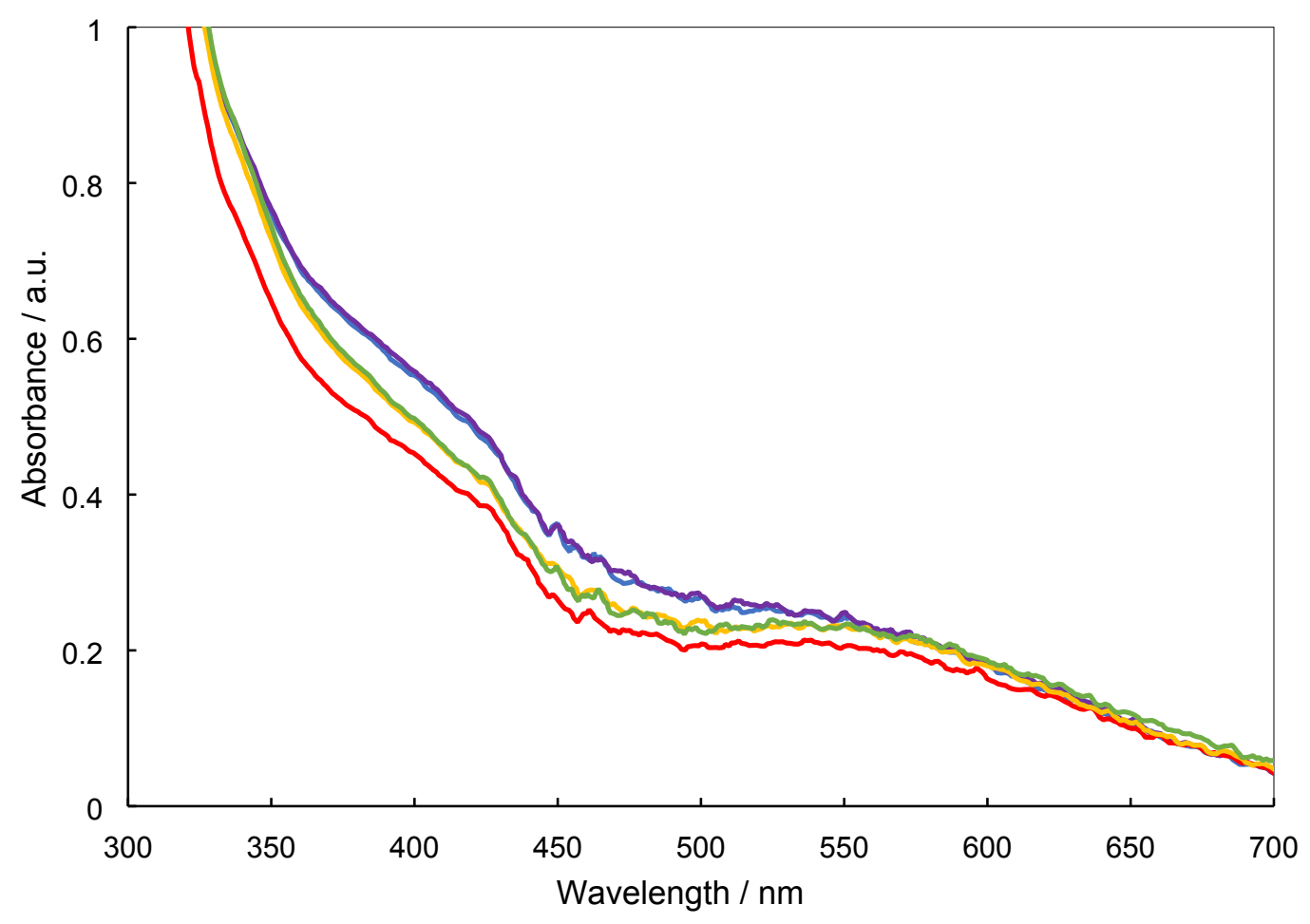


Figure S39: UV-Vis spectra of apo-GOase 4 h After addition of $\mathrm{Cu}(-)$, 1oh after addition of $\mathrm{Cu}(-)$. The rainbow spectra in between are taken at $2 \mathrm{~h}$ intervals in between

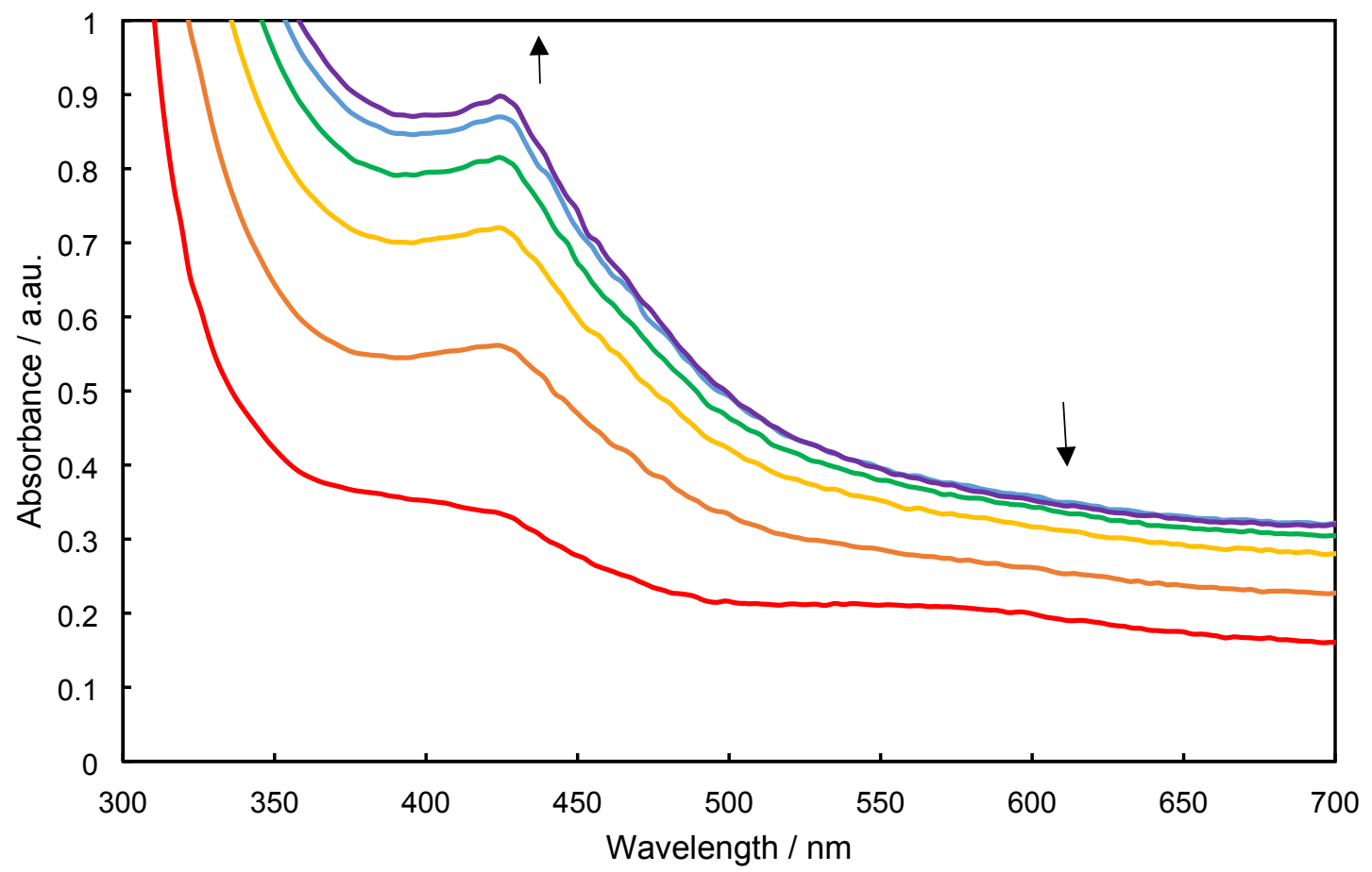

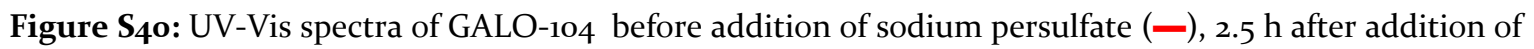
sodium persulfate (-). The rainbow spectra in between are taken at 30 min intervals in between. The arrows indicate the direction of the changes

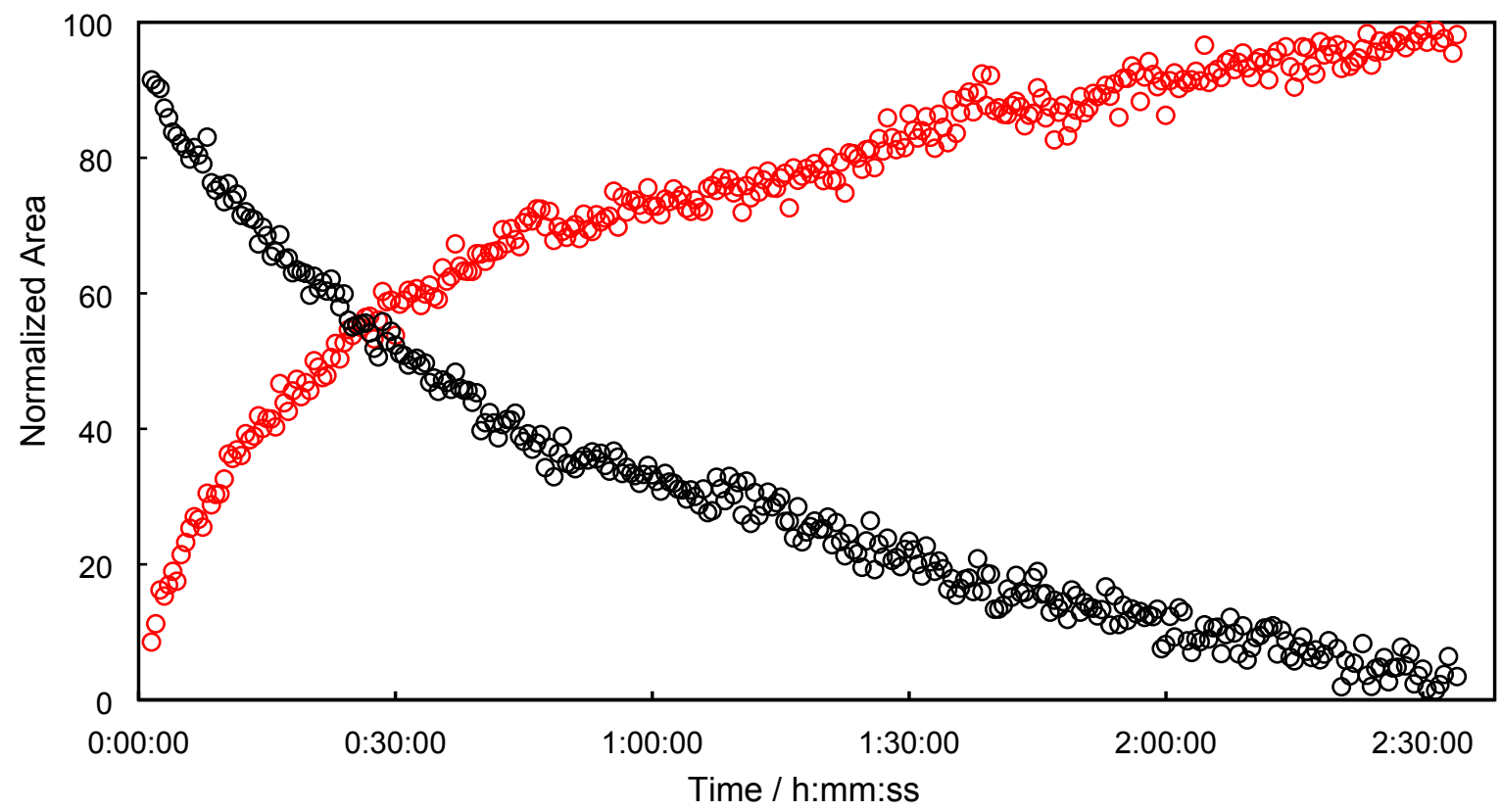


Figure S41: Single wavelength kinetic trace at $573 \mathrm{~nm}(\circ)$ and $428 \mathrm{~nm}(\circ)$. The area and the 2 point baseline was taken between $405 \mathrm{~nm}$ and $500 \mathrm{~nm}$ for the $428 \mathrm{~nm}$ peak. The area and the 2 point baseline was taken between $500 \mathrm{~nm}$ and $675 \mathrm{~nm}$ for the $573 \mathrm{~nm}$ peak. The normalized areas were plotted for clarity

\section{Enzyme activity assay.}

$30 \mathrm{mg}$ GOase was dissolved in $1 \mathrm{~mL}$ of water and $1 \mathrm{~mL}$ of $1 \mathrm{mM} \mathrm{CuSO}_{4}$ solution was added and the solution was shaken until homogeneous and $100 \mu \mathrm{L}$ of the resulting solution was added to $900 \mu \mathrm{L}$ of water to generate a 10x diluted GOase stock; $50 \mathrm{mg}$ Bovine catalase was dissolved in $1 \mathrm{~mL} \mathrm{H}_{2} \mathrm{O}$ and $100 \mu \mathrm{L}$ of the resulting solution was added to $900 \mu \mathrm{L}$ of water to generate a 10x diluted catalase stock; $20 \mathrm{mg}$ HRP PEO-301 was dissolved in $1 \mathrm{~mL} \mathrm{H}_{2} \mathrm{O}$ and $100 \mu \mathrm{L}$ of the resulting solution was added to $900 \mu \mathrm{L}$ of water to generate a 10x diluted HRP stock. To a 96well screening plate was added $80 \mu \mathrm{L} \mathrm{H}_{2} \mathrm{O}, 40 \mu \mathrm{L}$ of $1 \mathrm{M} \mathrm{NaPi}$ buffer at $\mathrm{pH} 7,120 \mu \mathrm{L}$ of $33.3 \mathrm{mM}$ 4-methoxybenzyl alcohol solution, $8 \mathrm{o} \mu \mathrm{L}$ 10x diluted GOase solution ( $0.24 \mathrm{mg}, 1.7 \mathrm{wt} \%$ ), $4 \mathrm{o} \mu \mathrm{L}$ of diluted catalase solution ( $0.2 \mathrm{mg}$, $1.4 \mathrm{wt} \%$ ), and either $40 \mu \mathrm{L}$ of water or $40 \mu \mathrm{L}$ of diluted HRP solution ( $0.08 \mathrm{mg}$, o.6 wt\%) and $20 \mu \mathrm{L}$ of $80 \mathrm{mM}$ $\mathrm{H}_{2} \mathrm{O}_{2}$. Each GOase (GALO-104, GALO-105, $\mathrm{M}_{1}, \mathrm{M}_{3-5}, \mathrm{~F}_{2}$ ) was placed in a different column of the $1^{\text {st }}$ row of a 96 well plate (without HRP) and on the $5^{\text {th }}$ row (with HRP). The resulting solutions were mixed using a multichannel pipettor and $100 \mu \mathrm{L}$ of the resulting solution was transferred to the next row and the well plate was placed as rapidly as possible in a Molecular Device Spectramax 384 and the formation of anisaldehyde was measured by recording the absorbance at $320 \mathrm{~nm}$ (see figure $\mathrm{S}_{42}$ ) every 30 s for $3 \mathrm{~h}$. The initial rate for the different GOases is shown below

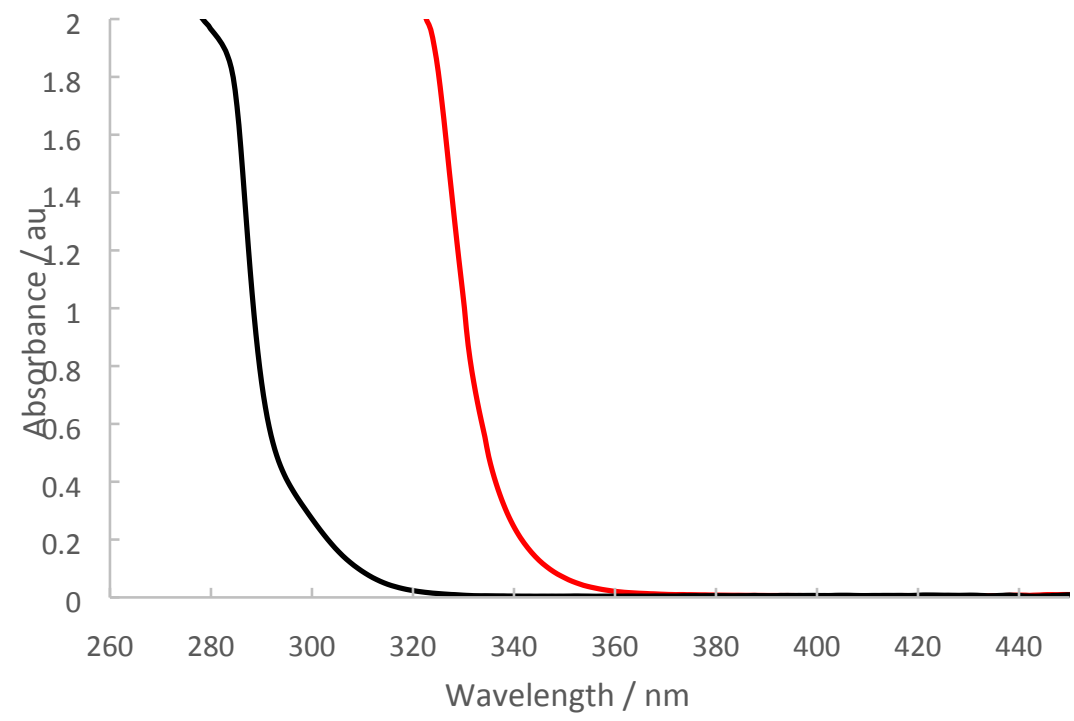

Figure S42: UV-Vis spectra of $10 \mathrm{mM}$ 4-methoxybenzyl alcohol (一) and $10 \mathrm{mM}$ anisaldehyde (一) in water. 


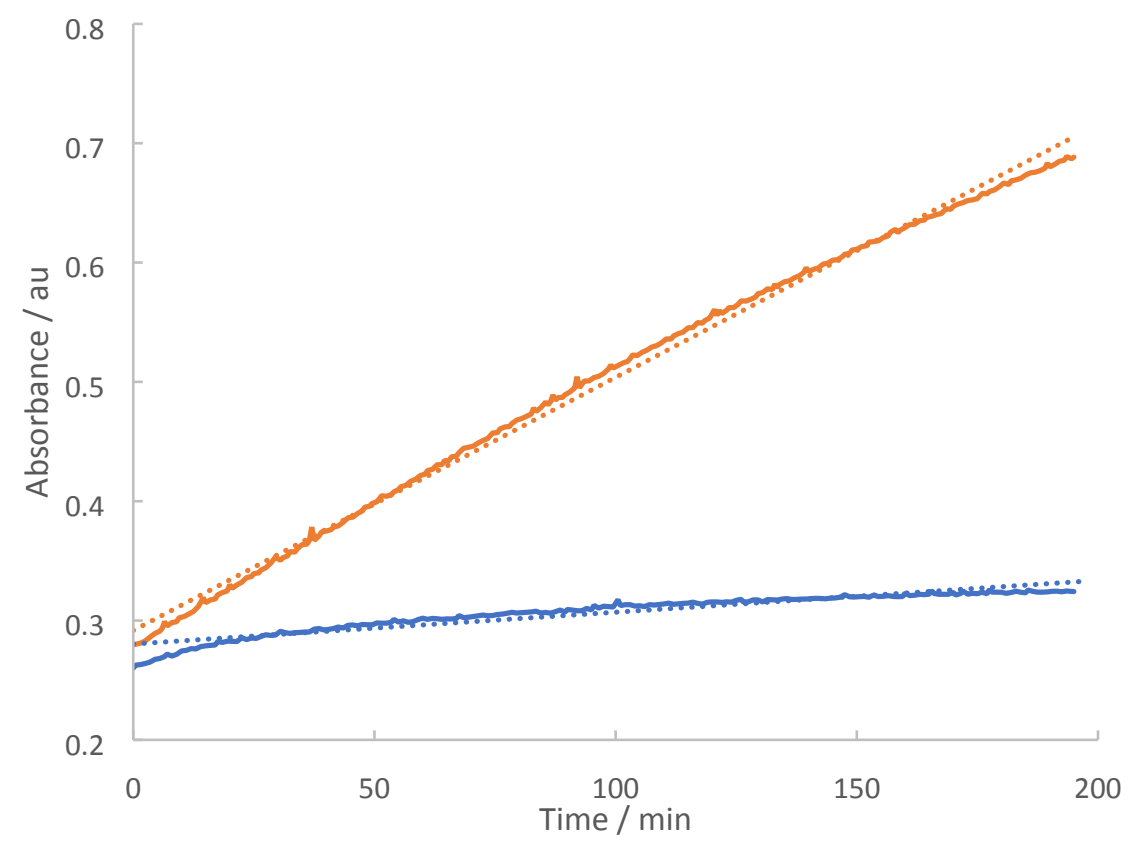

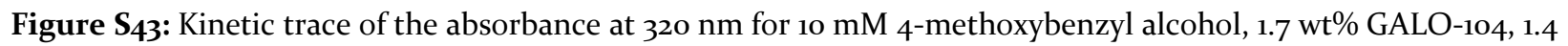
wt $\%$ catalase and either no HRP (-) or $0.6 \mathrm{wt} \% \mathrm{HRP}$ with $4 \mathrm{mM} \mathrm{H}_{2} \mathrm{O}_{2}(-)$. The linear regressions for each curve are shown in dashed

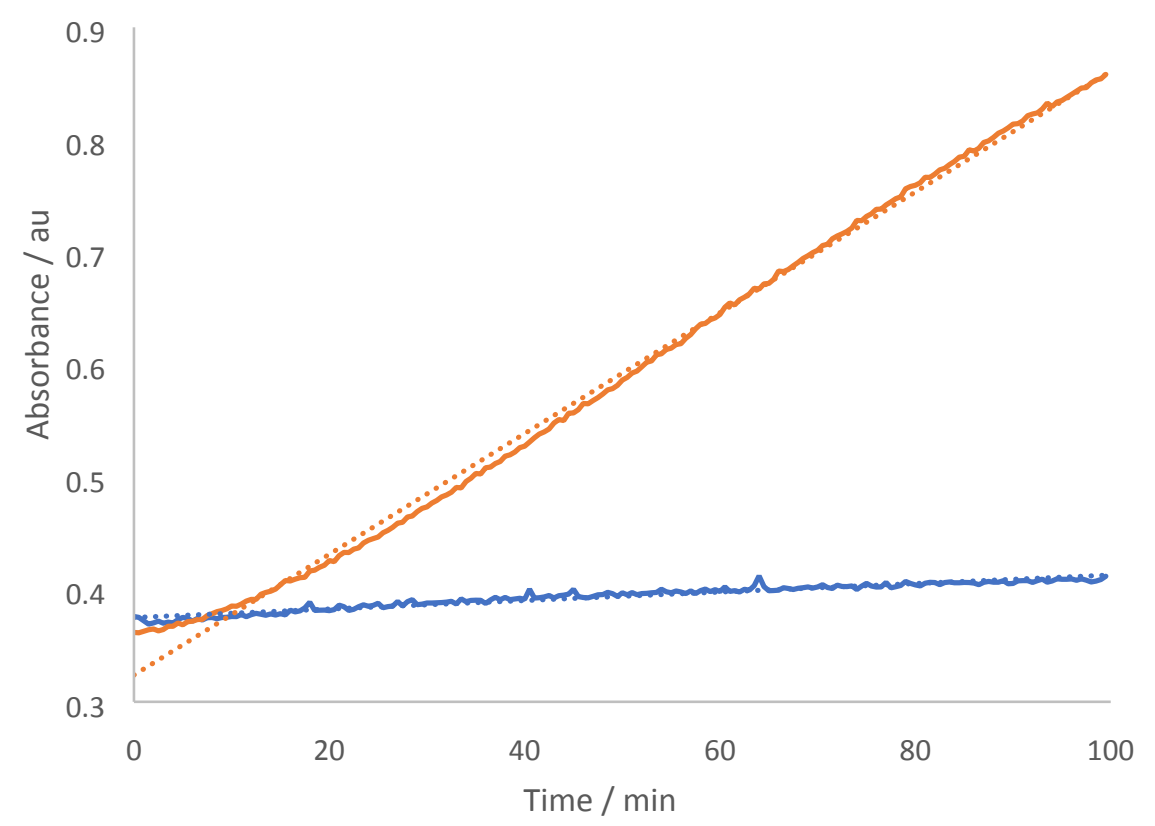

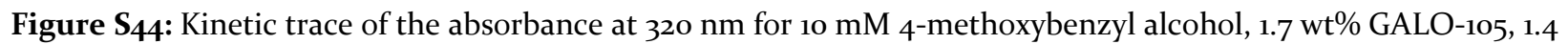
wt $\%$ catalase and either no HRP (-) or $0.6 \mathrm{wt} \% \mathrm{HRP}$ with $4 \mathrm{mM} \mathrm{H}_{2} \mathrm{O}_{2}(-)$. The linear regressions for each curve are shown in dashed 


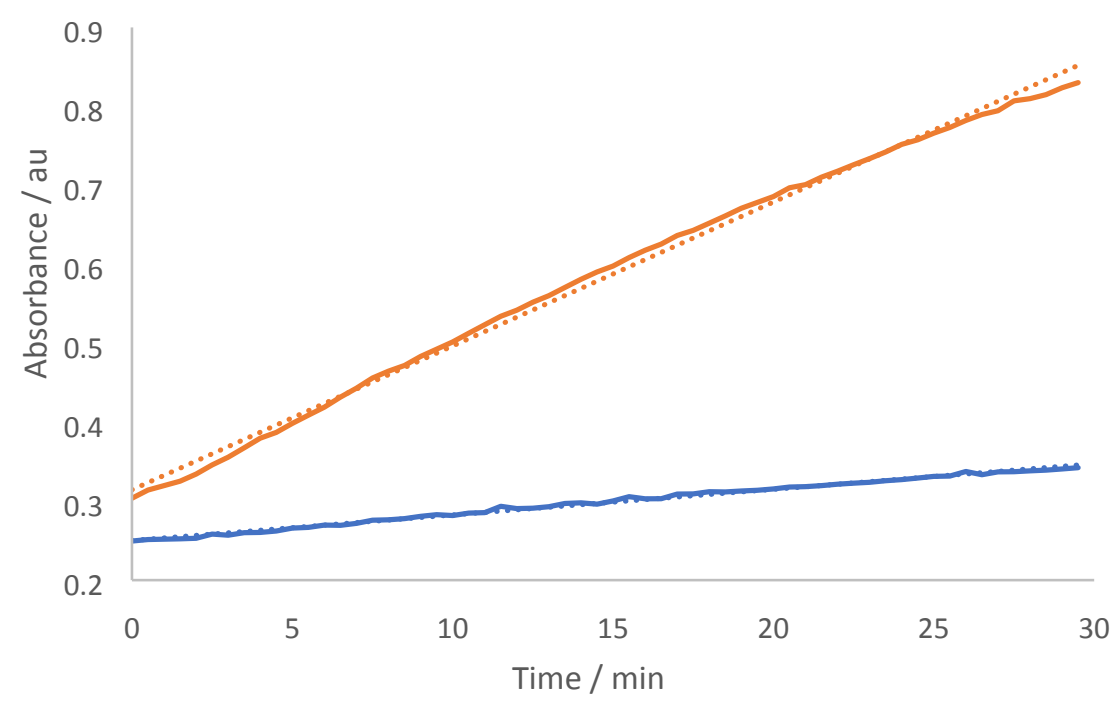

Figure S45: Kinetic trace of the absorbance at $320 \mathrm{~nm}$ for $10 \mathrm{mM}$ 4-methoxybenzyl alcohol, $1.7 \mathrm{wt} \% \mathrm{M}_{1}$ GOase, 1.4 wt $\%$ catalase and either no HRP ( - ) or o.6 wt $\% \mathrm{HRP}$ with $4 \mathrm{mM} \mathrm{H}_{2} \mathrm{O}_{2}(-)$. The linear regressions for each curve are shown in dashed

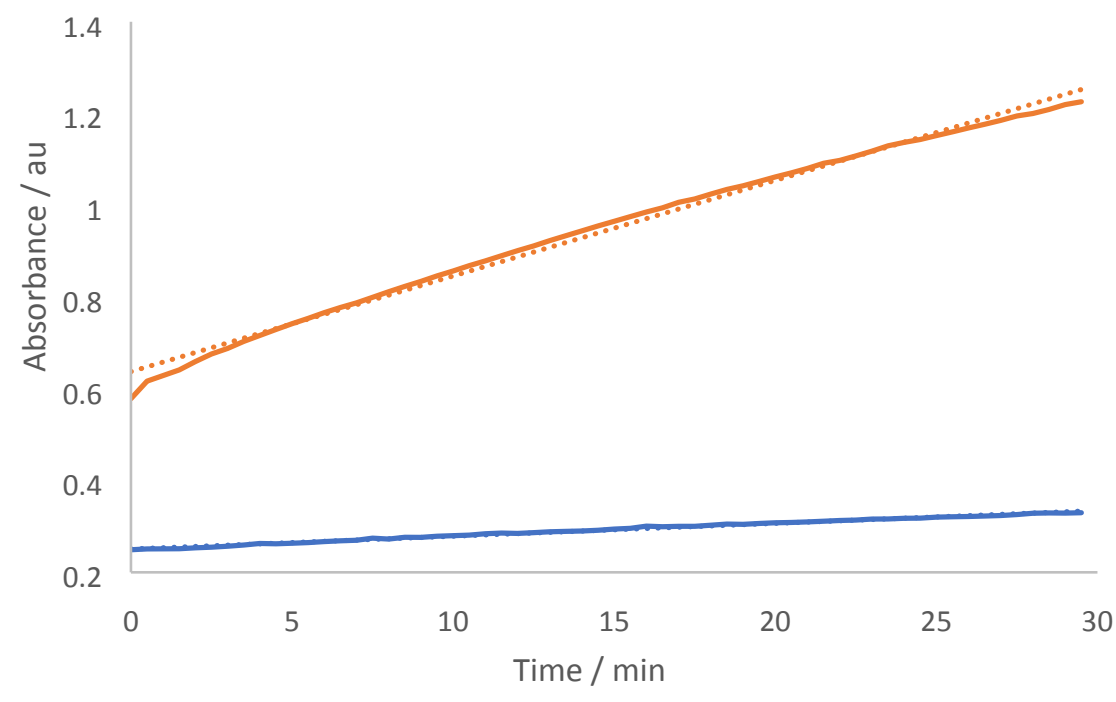

Figure S46: Kinetic trace of the absorbance at $320 \mathrm{~nm}$ for $10 \mathrm{mM}$ 4-methoxybenzyl alcohol, $1.7 \mathrm{wt} \% \mathrm{M}_{3-5}$ GOase, $1.4 \mathrm{wt} \%$ catalase and either no HRP (-) or $0.6 \mathrm{wt} \% \mathrm{HRP}$ with $4 \mathrm{mM} \mathrm{H}_{2} \mathrm{O}_{2}(-)$. The linear regressions for each curve are shown in dashed 


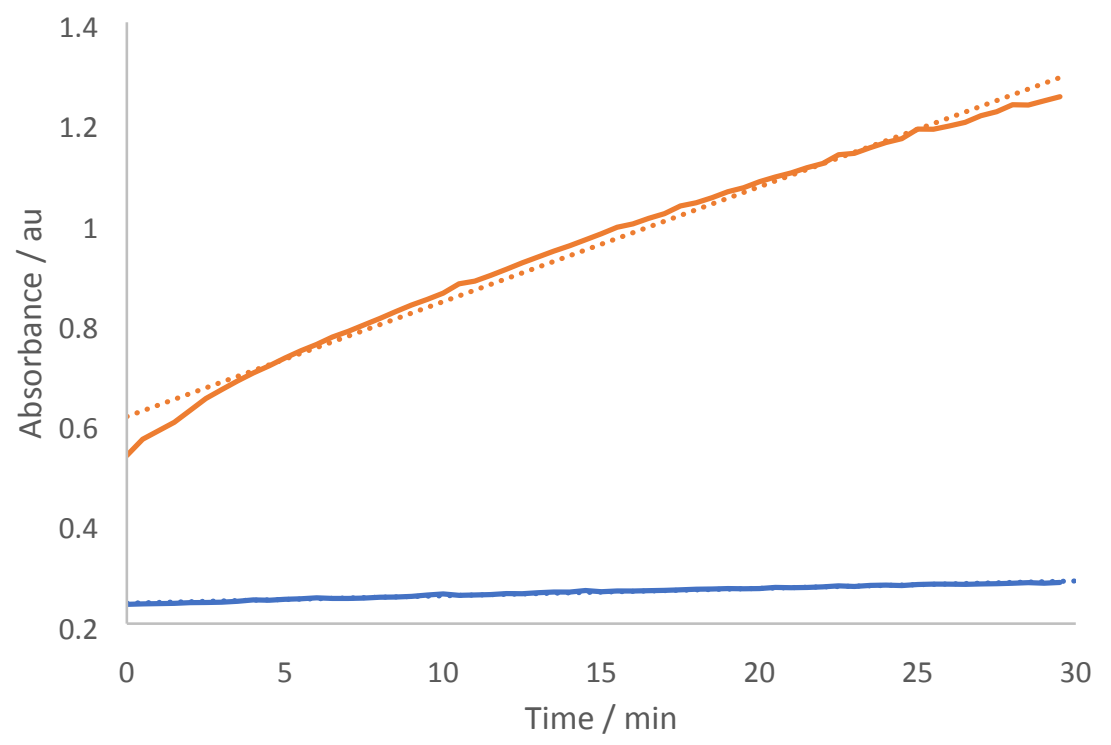

Figure S47: Kinetic trace of the absorbance at $320 \mathrm{~nm}$ for $10 \mathrm{mM}$ 4-methoxybenzyl alcohol, $1.7 \mathrm{wt} \% \mathrm{~F}_{2}$ GOase, 1.4 wt $\%$ catalase and either no HRP ( - ) or o.6 wt $\% \mathrm{HRP}$ with $4 \mathrm{mM} \mathrm{H}_{2} \mathrm{O}_{2}(-)$. The linear regressions for each curve are shown in dashed

Table S7: GOase activity with and without HRP activation.

\begin{tabular}{|l|c|c|c|c|c|}
\hline & GALO 104 & GALO 105 & M1 & M3-5 & F2 \\
\hline $\begin{array}{l}\text { Ratio of the GOase activity } \\
\text { with HRP/ without HRP }\end{array}$ & 7 & 13.5 & 5.7 & 7.4 & 15.3 \\
\hline $\begin{array}{l}\text { GOase } \\
\text { od } / \text { GOase } \\
\text { additioni } \text { ratio after } \mathrm{Cu}\end{array}$ & 0.14 & 0.07 & 0.17 & 0.13 & 0.07 \\
\hline
\end{tabular}

Amino acid and DNA sequences of the GOase enzymes.

GOase $\mathbf{M}_{1}$

MASAPIGSAIPRNNWAVTCDSAQSGNECNKAIDGNKDTFWHTFYGANGDPKPPHTYTIDMKTTQNVNGLSVLPR QDGNQNGWIGRHEVYLSSDGTNWGSPVASGSWFADSTTKYSNFETRPARYVRLVAITEANGQPWTSIAEINVFQ ASSYTAPQPGLGRWGPTIDLPIVPAAAAIEPTSGRVLMWSSYRNDAFEGSPGGITLTSSWDPSTGIVSDRTVTVTK HDMFCPGISMDGNGQIVVTGGNDAKKTSLYDSSSDSWIPGPDMQVARGYQSSATMSDGRVFTIGGSWSGGVFE KNGEVYSPSSKTWTSLPNAKVNPMLTADKQGLYRSDNHAWLFGWKKGSVFQAGPSTAMNWYYTSGSGDVKS AGKRQSNRGVAPDAMCGNAVMYDAVKGKILTFGGSPDYQDSDATTNAHIITLGEPGTSPNTVFASNGLYFARTF HTSVVLPDGSTFITGGQRRGIPFEDSTPVFTPEIYVPEQDTFYKQNPNSIVRAYHSISLLLPDGRVFNGGGGLCGDC TTNHFDAQIFTPNYLYDSNGNLATRPKITRTSTQSVKVGGRITISTDSSISKASLIRYGTATHTVNTDQRRIPLTLTN NGGNSYSFQVPSDSGVALPGYWMLFVMNSAGVPSVASTIRVTQGGGGSWSHPQFEK

GOase $\mathbf{M}_{3-5}$

MASAPIGSAIPRNNWAVTCDSAQSGNECNKAIDGNKDTFWHTFYGANGDPKPPHTYTIDMKTTQNVNGLSVLPR QDGNQNGWIGRHEVYLSSDGTNWGSPVASGSWFADSTTKYSNFETRPARYVRLVAITEANGQPWTSIAEINVFQ ASSYTAPQPGLGRWGPTIDLPIVPAAAAIEPTSGRVLMWSSYRNDAFEGSPGGITLTSSWDPSTGIVSDRTVTVTK HDMFCPGISMDGNGQIVVTGGNDAKKTSLYDSSSDSWIPGPDMQVARGYQSSATMSDGRVFTIGGSFSGGVFEK 
NGEVYSPSSKTWTSLPNAKVNPMLTADKQGLYMSDNHAWLFGWKKGSVFQAGPSTAMNWYYTSGSGDVKSA

GKRQSNRGVAPDAMCGNAVMYDAVKGKILTFGGSPDYTDSDATTNAHIITLGEPGTSPNTVFASNGLYFARTFH

TSVVLPDGSTFITGGQRRGIPFEDSTPVFTPEIYVPEQDTFYKQNPNSIVRAYHSISLLLPDGRVFNGGGGLCGDCT

TNHFDAQIFTPNYLYDSNGNLATRPKITRTSTQSVKVGGRITISTDSSISKASLIRYGTATHTVNTDQRRIPLTLTNN

GGNSYSFQVPSDSGVALPGYWMLFVMNSAGVPSVASTIRVTQGGGGSWSHPQFEK

\section{References.}

[1] B. Hu, C. DeBruler, Z. Rhodes, T. L. Liu, J. Am. Chem. Soc. 2017, 139, 1207-1214.

[2] A. F. Neto, J. Miller, V. F. De Andrade, S. Y. Fujimoto, M. M. De Freitas Afonso, F. C. Archanjo, V. A. Darin, M. L. Andrade E Silva, Á. D. L. Borges, G. Del Ponte, Z. Anorg. Allg. Chem. 2002, 628, $209-216$.

[3] M. A. Huffman, A. Fryszkowska, O. Alvizo, M. Borra-Garske, K. R. Campos, K. A. Canada, P. N. Devine, D. Duan, J. H. Forstater, S. T. Grosser, H. M. Halsey, G. J. Hughes, J. Jo, L. A. Joyce, J. N. Kolev, J. Liang, K. M. Maloney, B. F. Mann, N. M. Marshall, M. McLaughlin, J. C. Moore, G. S. Murphy, C. C. Nawrat, J. Nazor, S. Novick, N. R. Patel, A. Rodriguez-Granillo, S. A. Robaire, E. C. Sherer, M. D. Truppo, A. M. Whittaker, D. Verma, L. Xiao, Y. Xu, H. Yang, Science 2019, 366, 12551259 .

[4] H. C. Johnson, S. Zhang, A. Fryszkowska, S. Ruccolo, S. A. Robaire, A. Klapars, N. R. Patel, A. M. Whittaker, M. A. Huffman, N. A. Strotman, Org. Biomol. Chem. 2o21, doi: 10.1039/DoOBo2395G.

[5] C. M. Micklitsch, O. Alvizo, J. Nazor, H. C. Maniar, M. J. Krawczyk, M. T. Borra-Garske, N. Subramanian, A. Fryszkowska, N. M. Marshall, A. Rodriguez-Granillo, D. Verma, D. Andrews, Engineered Galactose Oxidase Variant Enzymes, 2020, WO 2020/014049 A1.

[6] L. Y. Jiang, J. J. Ming, L. Y. Wang, Y. Y. Jiang, L. H. Ren, Z. C. Wang, W. C. Cheng, Green Chem. 2ozo, 22, $1156-1163$.

[7] B. R. Kim, H. G. Lee, E. J. Kim, S. G. Lee, Y. J. Yoon, J. Org. Chem. 2010, 75, 484-486.

[8] A. Correa, R. Martín, J. Am. Chem. Soc. 2oo9, 131, 15974-15975.

[9] R. R. Perrotta, A. H. Winter, W. H. Coldren, D. E. Falvey, J. Am. Chem. Soc. 2o11, 133, $15553-15558$.

[10] M. Stephan, J. Panther, F. Wilbert, P. Ozog, T. J. J. Müller, Eur. J. Org. Chem. 2020, $2020,2086-2092$.

[11] K. Parikka, M. Tenkanen, Carbohydr. Res. 2009, 344, 14-20.

[12] D. T. Yin, S. Urresti, M. Lafond, E. M. Johnston, F. Derikvand, L. Ciano, J. G. Berrin, B. Henrissat, P. H. Walton, G. J. Davies, H. Brumer, Nat. Commun. 2015, 6, 10197.

[13] J. A. Castillo, C. Guérard-Hélaine, M. Gutiérrez, X. Garrabou, M. Sancelme, M. Schürmann, T. Inoue, V. Hélaine, F. Charmantray, T. Gefflaut, L. Hecquet, J. Joglar, P. Clapés, G. A. Sprenger, M. Lemaire, Adv. Synth. Catal. 2010, 352, 1039-1046. 